\title{
TRADE \\ INSTRUCTIONAL MATERIALS FOR \\ SARA/OSHA TRAINING \\ VOLUME II \\ Managers and Supervisors Training
}

\author{
Prepared by
}

Assessment and Field Support Programs

Training and Management Systems Division

Oak Ridge Associated Universities

$$
\text { and }
$$

Technical Resources and Training Section

Environmental and Health Protection Division

Oak Ridge National Laboratory

Martin Marietta Energy Systems, Inc.

\author{
for the \\ Office of Nuclear Safety \\ and
}

Office of Operational Safety

Deputy Assistant Secretary for Safety, Health, and Quality Assurance

Assistant Secretary for Environment, Safety, and Health

$$
\text { and }
$$

Office of Emergency Operations

Assistant Secretary for Defense Programs

U.S. Department of Energy

March 1989

\section{OSTI} This report was prepared under contract number DE-AC05-76OR00033 between the U.S. Department of
Energy and Oak Ridge Associated Universities. 
Oak RIdge Associated Universities is a private, not-for-profit association of 49 colleges and universities and a management and operating contractor of the U.S. Department of Energy. ORAU's mission is to foster, encourage, and engage in the identification and development of solutions to scientific, engineering, technical, medical, and human resource problems through the resources available to ORAU and its member universities. In support of this mission, ORAU provides diverse services (principally academic outreach, research, training and education, technical assistance, and technology transfer) for DOE, ORAU's member institutions, other colleges and universities, and other private and governmental organizations. Established in 1946, ORAU was one of the first university-based, science-related corporate management groups.

The Training and Management Systems Division (TMSD) has primary responsibility for designing solutions to training and human resource management problems. The Division designs, delivers, and manages training programs for DOE and other clients in a coordinated and accountable manner which provides continuity and maximizes the lessons learned from each program. The Division also researches forces and trends in training and development, emerging technologies, and models of learning systems.

\section{NOTICES}

The opinions expressed herein do not necessarily roflect the opinions of the sponsoring institutions of Oak Ridge Associated Universities.

This report was prepered as an account of work sponsored by the United States Government. Neither the United States Government nor the U.S. Depertment of Energy, nor any of their employees, makes any warranty, express or implled, or assumes any legal liability or responsibility for the accuracy, completeness, or usefulness of any information, apparatus, product, or process disclosed, or represents that its use would not infringe privately owned rights. Reference herein to any specific commercial product, process, or service by trade name, mark, manufacturer, or otherwise, does not necessarily constitule or imply lis endorsement or recommendation, or favoring by the U.S. Government or any agency thereof. The views and opinions of authors expressed herein do not necessarily state or reflect those of the U.S. Government or any agency thereof. 
INTRODUCTION

This eight-hour training course has been developed for supervisors and managers of hazardous waste operations and waste cleanup activities at Oak Ridge National Laboratory. Course content was influenced by the listing of recommended topics for managers and supervisors given in the Occupational Safety and Health Guidance Manual for Hazardous Waste Site Activities as well as site-specific needs and interests. This training includes an overview of the influence of regulations and site characteristics on remedial action strategies at ORNL. Keeping the theme of worker health and safety, a significant portion of the training is concerned with the complex task of personal protective clothing selection and the physiological and human factors that must be considered with use of protective ensembles. Another module promotes awareness of the laboratory's hazardous chemical reporting requirements and interaction with the state and local community under SARA Title III. Because the legal aspect of worker supervision is of great interest to supervisors of hazardous waste operations, an attempt is made to address concerns and answer questions on this subject. Since hazardous waste operations and activities are currently receiving a high level of media attention, "Handling the Press" discusses strategies to be used in intervlew situations for more effective ana confident communication. Because the final rule requires three days of training in the field under direct supervision of a trained and experienced supervisor, a workshop in on-the-job training is included, with discussions about documentation of this type of training. A group-oriented exercise in potential problem analysis and contingency planning applied to cleanup of a hazardous waste site completes the day of training.

Where possible, we have provided in this volume generic materials, proposed training strategies, and some sample materials for site-specific information. To date we have conducted this course four times, training 36 managers and supervisors.

Although this course was developed before the final rule for 29 CFR 1910.120 was published (March 6, 1989), it meets the criteria as spelled out in the final rule for the eight-hour manager training.

D. Allen White

Allison Von Gruenigen

Emily D. Copenhaver

Technical Resources and Training Section Environmental and Health Protection Division Oak Ridge National Laboratory

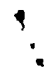

TRADE SARA/OSHA Training: March 1989 


\section{PREFACE}

This document provides instructional materials for an eight-hour training course for managers and supervisors of hazardous waste sites. It is one of three volumes of course materials TRADE is preparing to help DOE contractor training staff comply with 29 CFR 1910.120, the Occupational Health and Safety Administration (OSHA) rule that implements Title I of the Superfund Amendments and Reauthorization Act (SARA) of 1986. OSHA's final rule for hazardous waste operators was published in the Federal Register of March 6, 1989 (54 FR 9294).

Combined with the materials in Volumes I and III and with appropriate site-specific information, these materials will help DOE contractors to meet the requirements of 1910.120 (e) that "on-site management and supervisors directly responsible for, or who supervise employees engaged in, hazardous waste operations" receive the same initial training as that of the employees they supervise and at least eight additional hours of specialized training in managing hazardous waste operations.

Contractor staff preparing a manager/supervisor course should note that paragraph (e)(4) of the final rules specifies training "on such topics as, but not limited to, the employer's safety and health program and the associated employee training program, personal protective equipment program, spill containment program, and health hazard monitoring techniques." We believe that training staff can address these topics within the framework of the instructional materials provided here by adding information on specific facility programs and practices to Modules III, "Selecting and Using Personal Protective Equipment," and VIII, "Potential Problem Analysis and Contingency Planning."

Volume I of the series, "General Site Worker Training," provides materials for a 24-hour course for those workers on site occasionally for specific, limited tasks; on sites known to be safe; or engaged in routine activities on sites covered by the Resources Conservation and Recovery Act (RCRA). It was published in April 1988 and has now been distributed to 116 recipients throughout the DOE system. Volume III is currently in preparation and contains materials for a 16 -hour course that, combined with the 24-hour training, covers the full 40 hours needed by remedial action site workers.

The response to Volume $I$ and the numerous requests from contractor staff and others for comparable materials suggest that this series is meeting a real need at DOE contractor facilities. 
The instructional materials provided in all three volumes were initially developed by the Technical Resources and Training Section staff, Environmental and Health Protection Division, Oak Ridge National

Laboratory. We appreciate the willingness of the TRT staff to share their labors with the rest of the DOE community. We recognize and are grateful for the extra effort required to produce this "generic" version of their ORNL-specific materials. Our hope is that by building from these documents, contractor training staff are able to create their own site-appropriate training programs more efficiently.

Tina McKinley

Executive Director 


\begin{abstract}
Page
Introduction $\ldots \ldots \ldots \ldots \ldots \ldots \ldots \ldots \ldots \ldots \ldots \ldots \ldots \ldots \ldots \ldots \ldots \ldots$

Module I - Remedial Action Strategies $\ldots \ldots \ldots \ldots \ldots \ldots \ldots \ldots \ldots \ldots \ldots$

Module II - Handling the Press $\ldots \ldots \ldots \ldots \ldots \ldots \ldots \ldots \ldots \ldots \ldots \ldots \ldots$ II -1

Module III - Selecting and Using Personal Protective Equipment....... III-1

Module IV - Material Safety Data Sheets Exercise $\ldots \ldots \ldots \ldots \ldots \ldots \ldots$ IV-1

Module V - SARA Title III: Emergency Planning and Community Right to know .......................... $v-1$

Module VI - Legal Aspects of Supervision $\ldots \ldots \ldots \ldots \ldots \ldots \ldots \ldots \ldots$ VI-1

Module VII - On-the-Job Training Skills $\ldots \ldots \ldots \ldots \ldots \ldots \ldots \ldots \ldots$ VII-1

Module VIII - Potential Problem Analysis and Contingency Planning ...... VIII-1

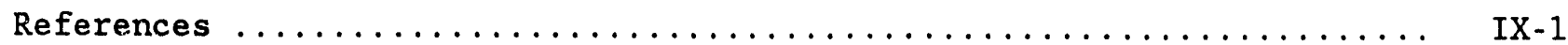




\section{SARA/OSHA TRAINING FOR}

HAZARDOUS WASTE SITE ACTIVITIES

29 CFA 1910.120

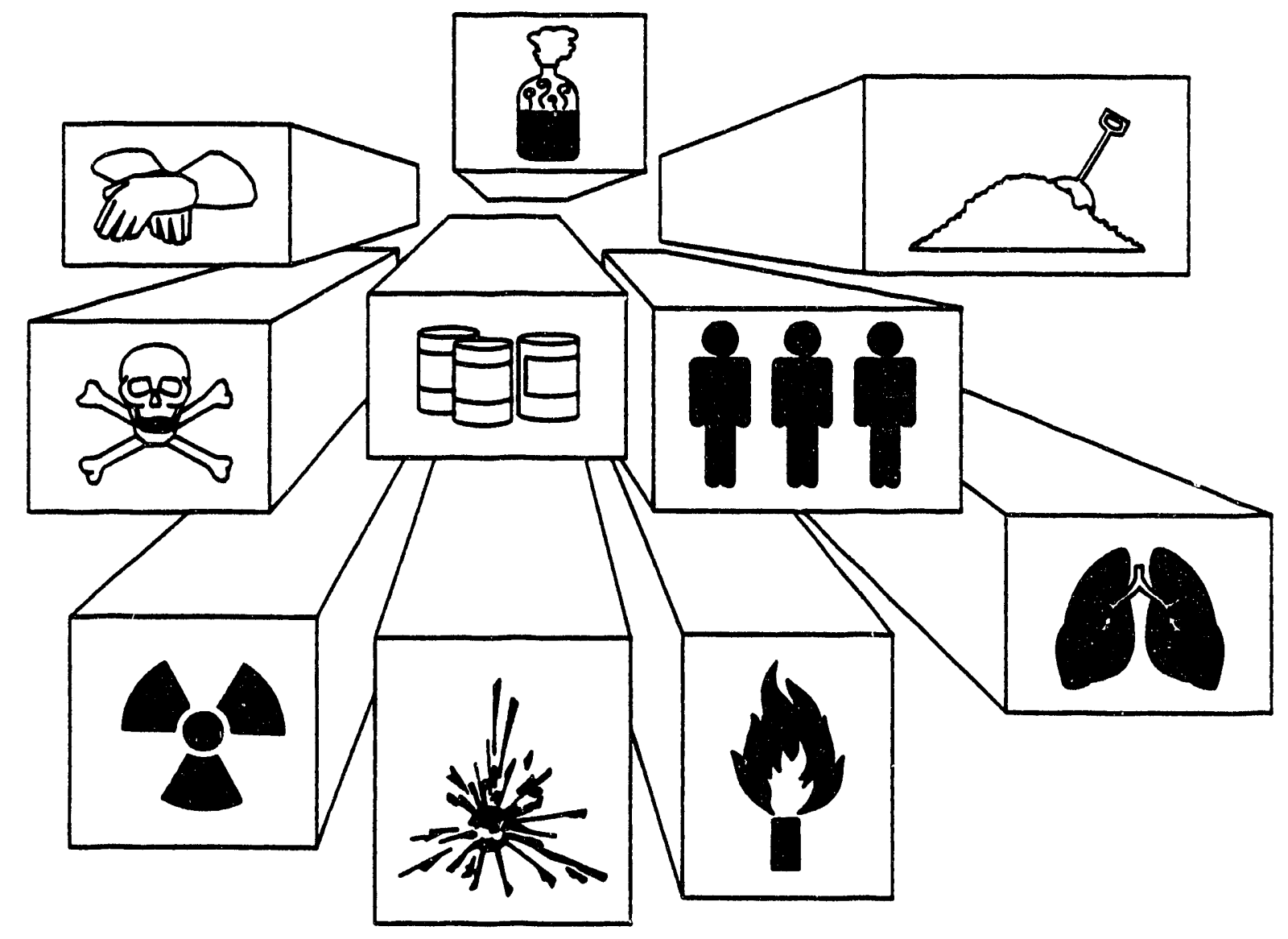




\section{INTRODUCTION}

This eight-hour training course has been developed for supervisors and managers of hazardous waste operations and waste cleanup activities at Oak Ridge National Laboratory. Course content was influenced by the listing of recommended topics for managers and supervisors given in the Occupational Safety and Health Guidance Manual for Hazardous Waste Site Activities as well as site-specific needs and interests. This training includes an overview of the influence of regulations and site characteristics on remedial action strategies at ORNL. Keeping the theme of worker health and safety, a significant portion of the training is concerned with the complex task of personal protective clothing selection and the physiological and human factors that must be considered with use of protective ensembles. Another module promotes awareness of the laboratory's hazardous chemical reporting requirements and interaction with the state and local community under SARA Title III. Because the legal aspect of worker supervision is of great interest to supervisors of hazardous waste operations, an attempt is made to address concerns and answer questions on this subject. Since hazardous waste operations and activities are currently receiving a high level of media attention, "Handling the Press" discusses strategies to be used in interview situations for more effective and confident communication. Because the final rule requires three days of training in the field under direct supervision of a trained and experienced supervisor, a workshop in on-the-job training is included, with discussions about documentation of this type of training. A group-oriented exercise in potential problem analysis and contingency planning applied to cleanup of a hazardous waste site completes the day of training.

Where possible, we have provided in this volume generic materials, proposed training strategies, and some sample materials for site-specific information. To date we have conducted this course four times, training 36 managers and supervisors.

Although this course was developed before the final rule for 29 CFR 1910.120 was published (March 6, 1989), it meets the criteria as spelled out in the final rule for the eight-hour manager training.

D. Allen White

Allison Von Gruenigen

Emily D. Copenhaver

Technical Resources and Training Section Environmental and Health Protection Division Oak Ridge National Laboratory 
REMEDIAL ACTION STRATEGIES

SCOPE

This module presents an overview of remedial action at the DOE contractor installation. The definition, goals, strategies, and components of remedial action program implementation are described, including identification of sites within the installation on which the individuals participating in the training courses may be expected to work.

(Suggested time - 1 hour)

\section{PARTICIPANT GOALS}

The participant will be able to:

1) Describe the goal of remedial action.

2) Define and describe three main factors that influence the installation's remedial action strategy. 


\section{INSTRUCTOR PREPARATION}

1. Review the remedial action plans and associated documentation for appropriate facilities or sites on the installation, including information on preliminary site characterization, corrective action, decommissioning and/or closure options, and regulatory interfaces.

2. Prepare a set of viewgraphs to supplement the generic ones included in this module. Some sample site-specific viewgraphs are included to aid in further development of the module.

3. Prepare site-specific information used in preliminary site characterization, including:

- On-site waste sources (MANAGER-04A SAMPLE)

- Off-site waste sources (MANAGER-04A1 SAMPLE)

- Waste handling and treatment systems (MANAGER-04B SAMPLE)

- Waste disposal methods (MANAGER-04C SAMPLE)

- Hydrogeologic characteristics (MANAGER-04D, -04D1 SAMPLE, MANAGER-04D2, -04D3 SAMPLE, -04D4 SAMPLE, -04D5 SAMPLE)

If waste area groupings are being employed on the installation, include a site-specific explanation (MANAGER-04E SAMPLE). Also use lists, maps, and/or photographs of remedial action sites.

4. Prepare site-specific information to supplement the generic information on regulatory interfaces (MANAGER-05,-05A,-05A1, 05B,-05C, -05D).

5. Prepare site-specific viewgraphs, if applicable, to review site decommissioning and closure options, decision factors, and option negatives (as outlined, MANAGER-06).

6. Prepare viewgraphs, if desired, giving information on the following phases of remedial action program implementation (MANAGER-07):

a. preliminary assessment and site investigation - preliminary surveys; Remedial Facilities Assessment Reports.

b. maintenance and surveillance - plans and implementation strategies for routine site maintenance and surveillance to ensure containment, surveillance documentation, and needed corrective actions;

c. remedial investigation/feasibility studies (RI/FS)

- development and implementation of characterization plans; alternative assessments for closure or decommissioning; and integration of the results through a comprehensive feasibility study. 


\section{d. technology demonstrations}

- demonstrations and evaluations of potential remedial action technologies; evaluations of past corrective actions;

e. corrective action

f. decommissioning and closure

- development of engineering designs and implementation of site decommissioning or closure actions for management of surplus facilities or for priority projects defined by the RI/FS process;

g. remedial action program support

- management and data base support for overall program; overall strategy to integrate information from results of Phases 1-6; analyses of institutional, regulatory, and technical issues; development of site closure criteria; and establishment of the EPA interface. Include a schedule if available. 


\section{INSTRUCTIONAL ACTIVITIES}

Note: The sample viewgraphs contain ORNL site-specific information.

1. Introduce the subject of this module. (MANAGER - 01)

2. Review the learning objectives. (OBJECTIVES)

3. Define the goal of remedial action. (MANAGER-02)

4. Discuss the remedial action strategy and those factors that influence it: preliminary site characterization; corrective action, decommissioning, and/or closure; and regulatory interfaces. (MANAGER -03)

5. Explain the topics that are covered in a preliminary site characterization. (MANAGER-04)

6. Describe the different types of on-site waste sources.

7. Discuss on-site sources related to your site. (MANAGER-04A SAMPLE)

8. Describe the different types of off-site waste sources.

9. Discuss your site-specific sources.

(MANAGER-04AI SAMPLE)

10. Describe waste handling and treatment systems in use at your site. (MANAGER-04B SAMPLE)

11. Describe examples of waste disposal methods such as solid waste storage areas, waste seepage pits, etc., employed at your site. (MANAGER-04C SAMPLE)

12. Describe hydrogeologic characteristics of the site: hydrology, geology, soil, anthropogenic features, and findings of transport and flow diversion studies.

(MANAGER-04D SAMPLE)

TRADE SARA/OSHA Training: March 1989

$I-4$ 
13. Explain the three components of hydrology--climate, groundwater, and surface water--and give examples.

(MANAGER-04D1 SAMPLE)

14. Explain the geology of the site with examples relevant to specific on-site locations.

(MANAGER-04D2 SAMPLE)

15. Explain the soil factors that affect remedial action. (IANAGER-04D3 SAMFLE)

16. Discuss the anthropogenic features of your site that have remedial action implications.

(MANAGER-04D4 SAMPLE)

17. Describe any studies of transport and flow diversion that have been conducted on your site.

(MANAGER-4D5 SAMPLE)

18. Describe Waste Area Groupings (WAGs), if applicable. (MANAGER-04E SAMPLE)

19. Review the regulatory influences on remedial action, and explain their impact on site characterization and cleanup. Note that facilities must meet either federal or state requirements, whichever are more stringent. (MANAGER-05)

20. Explain RCRA's requirements for solid waste management units and regulated units.

(MANAGER-05A)

21. Explain RCRA's requirements for underground storage tanks. (MANAGER-05A1)

22. Explain how the Clean Water Act affects remedial action. (MANAGER-05B)

23. Explain how the Safe Drinking Water Act affects remedial action. (MANAGER-05C)

24. Describe how CERCLA/SARA influences your facility. Discuss the consequences of a site being placed on the National Priorities List. (MANAGER-05D)

TRADE SARA/OSHA Training: March 1989 
25. Discuss options and decision factors for site decommissioning and closure. Include site-specific information.

(MANAGER-06)

26. Describe the implementation of a remedial action program, including the formal action plan, at your site. (MANAGER-07) 


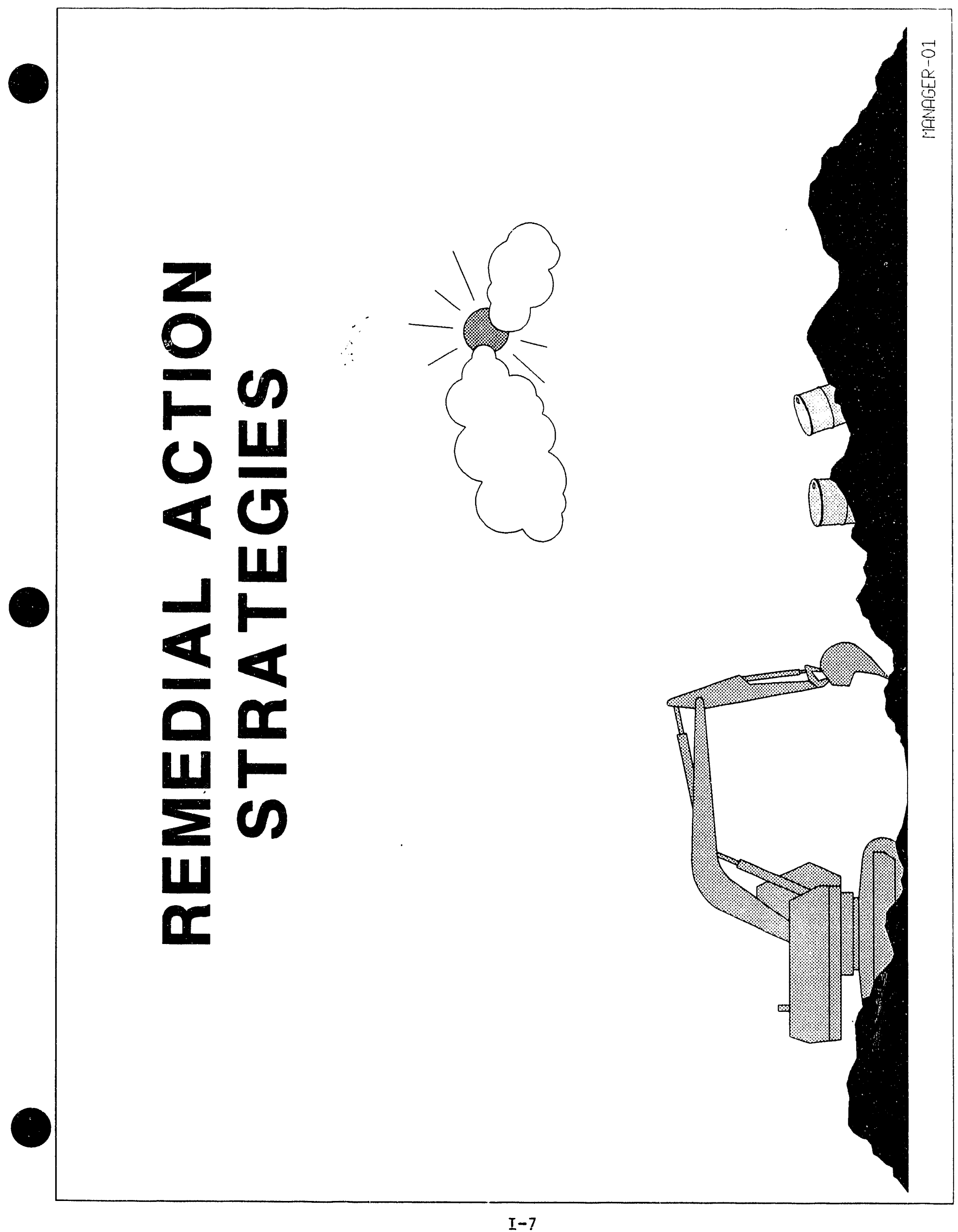




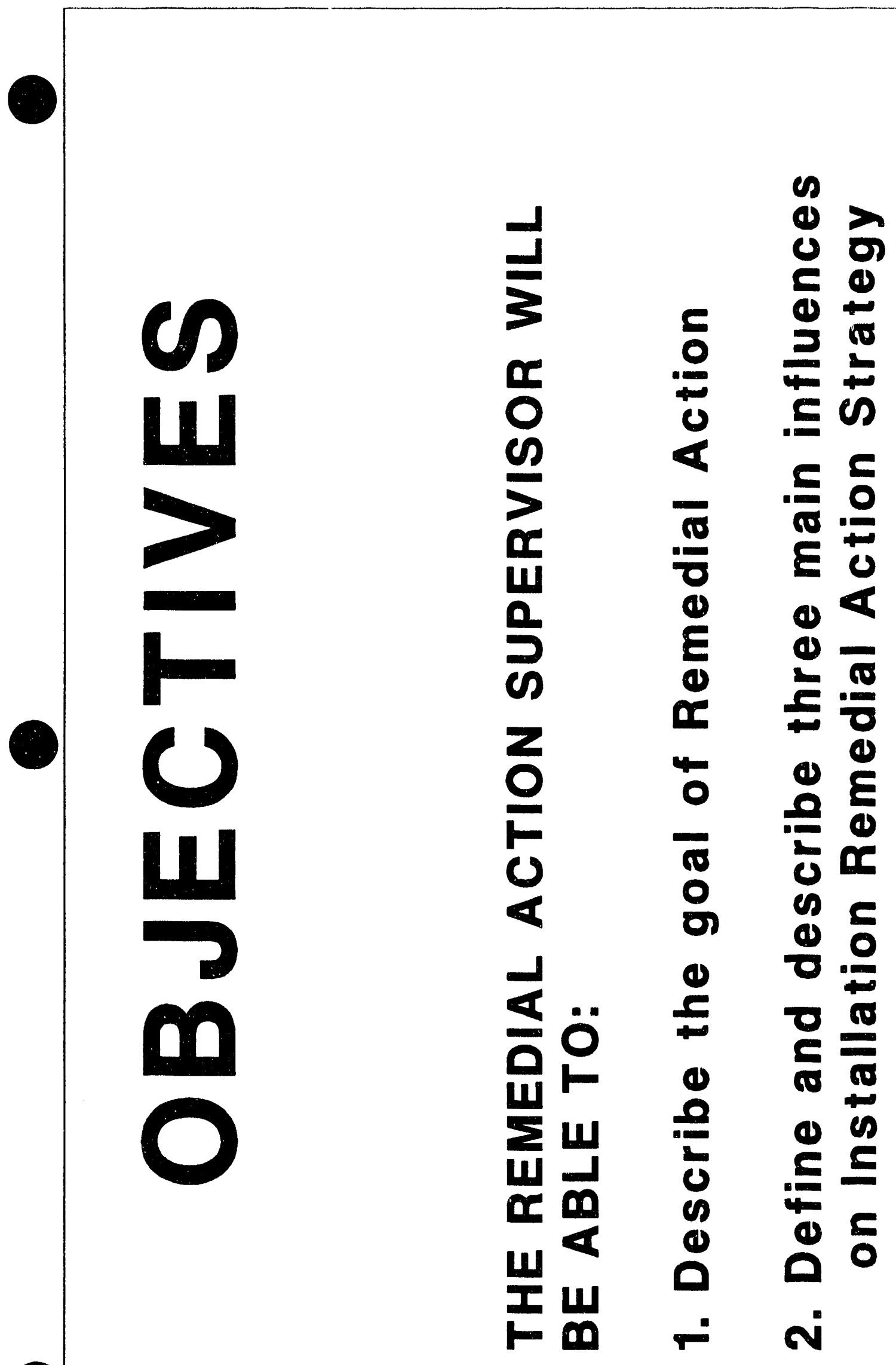




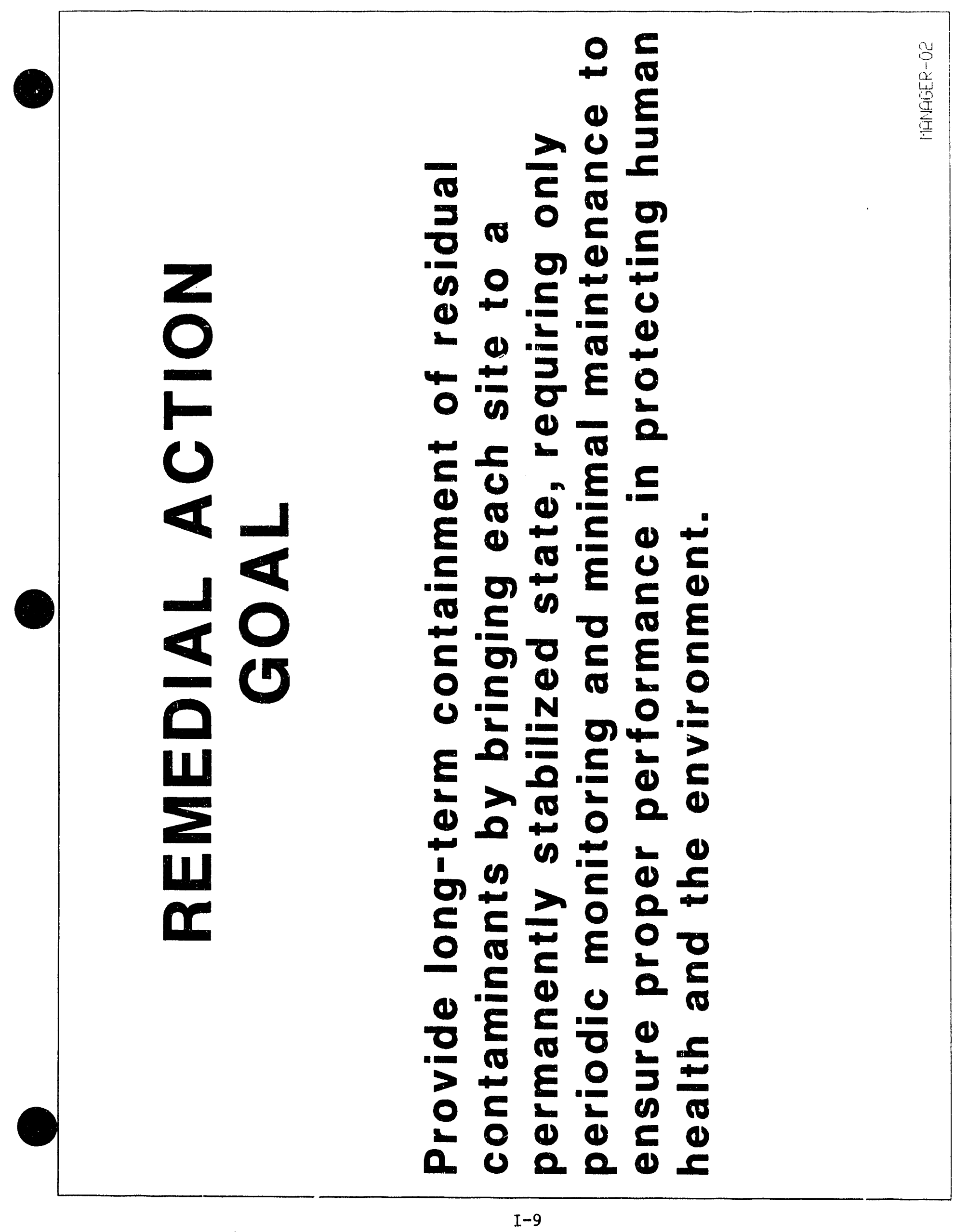




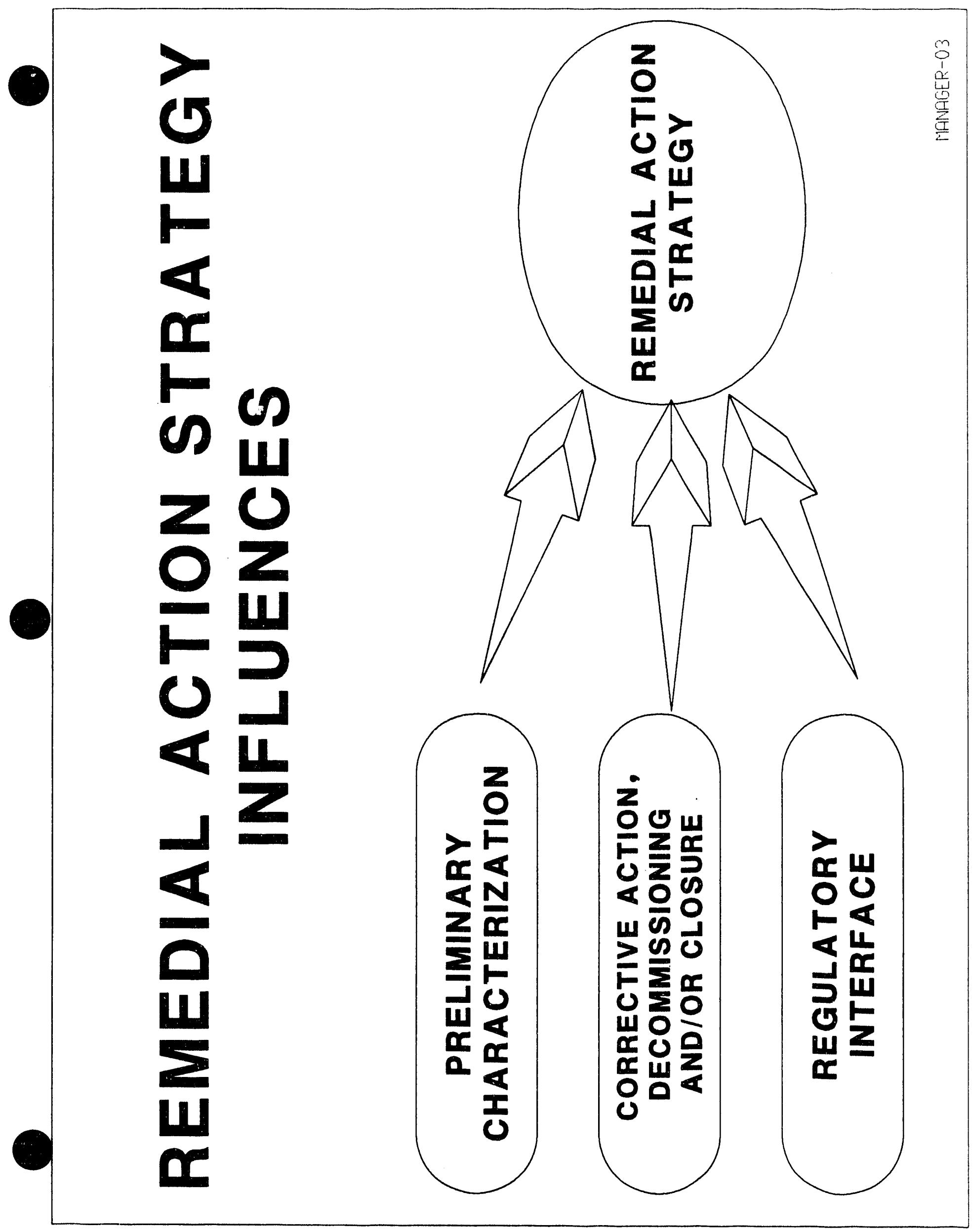

$I-10$

TRADE SARA/OSHA Training: March 1989 


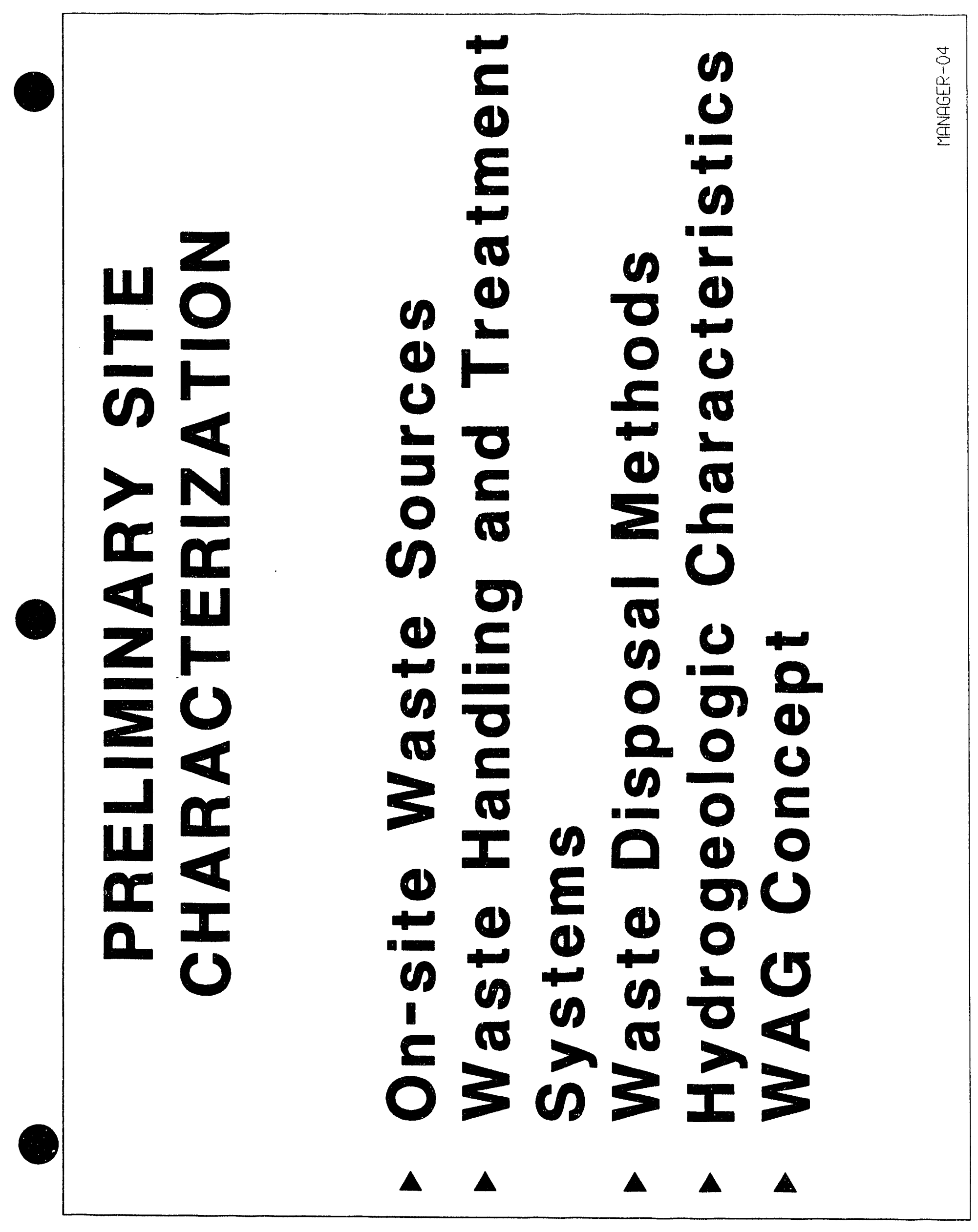




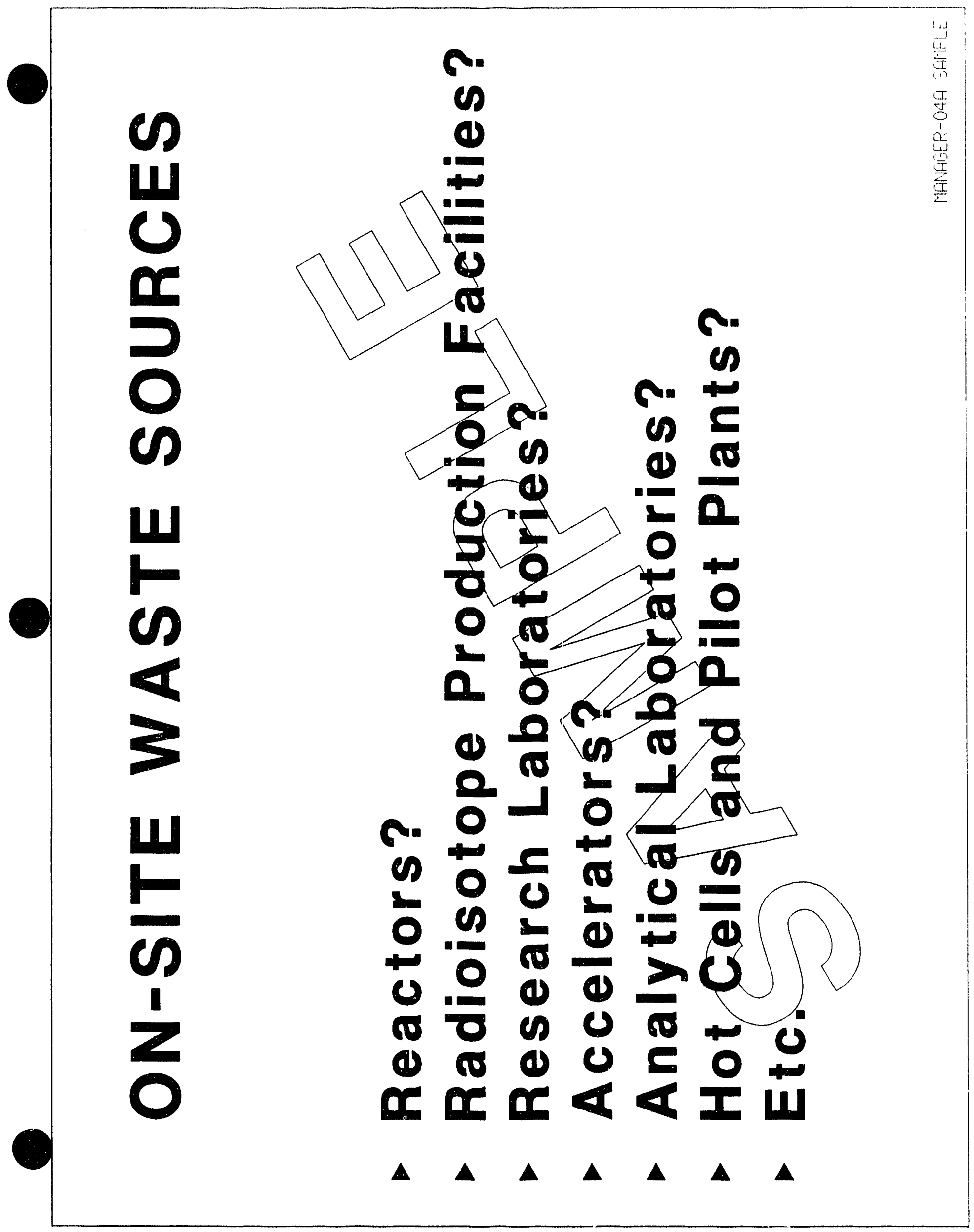




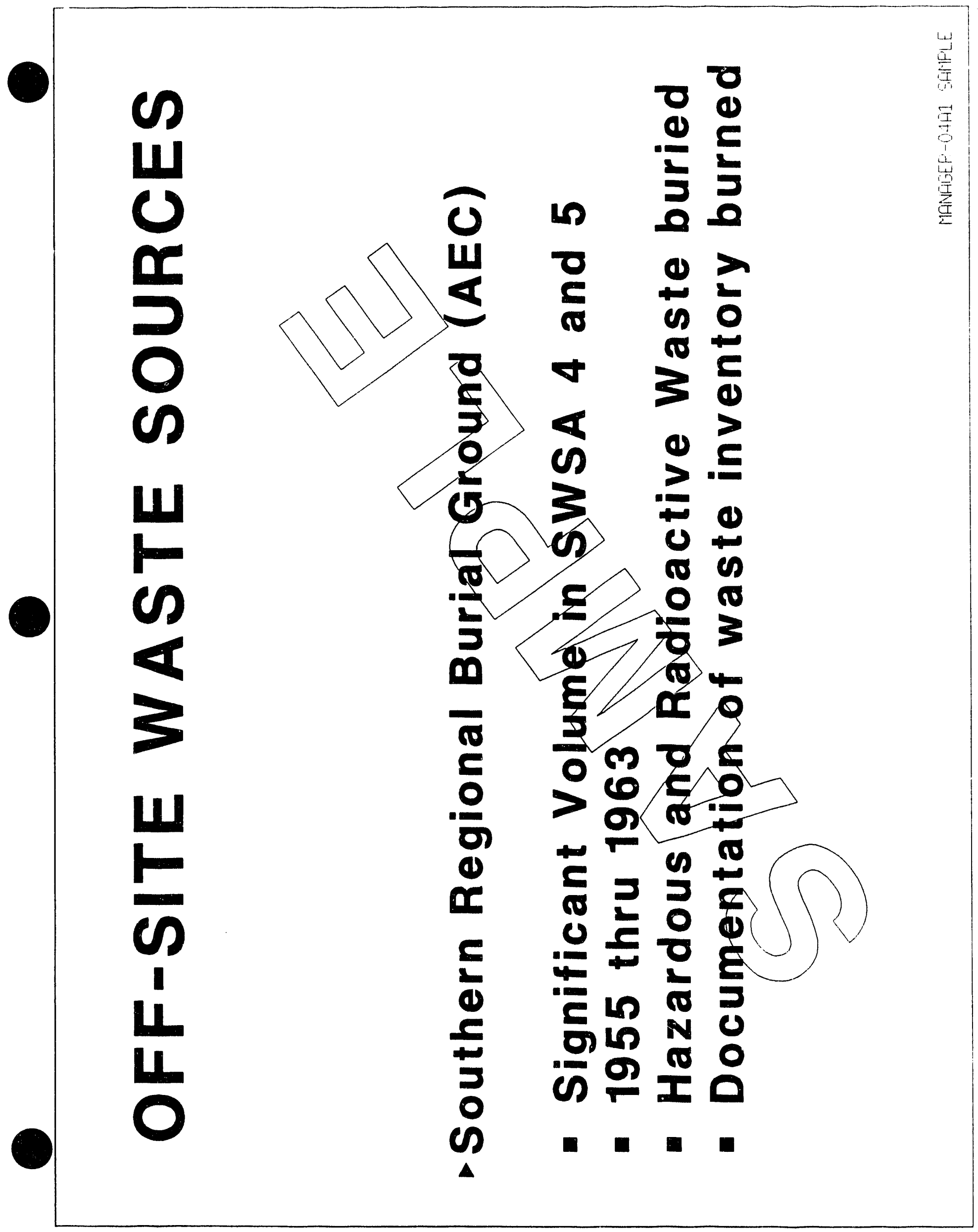




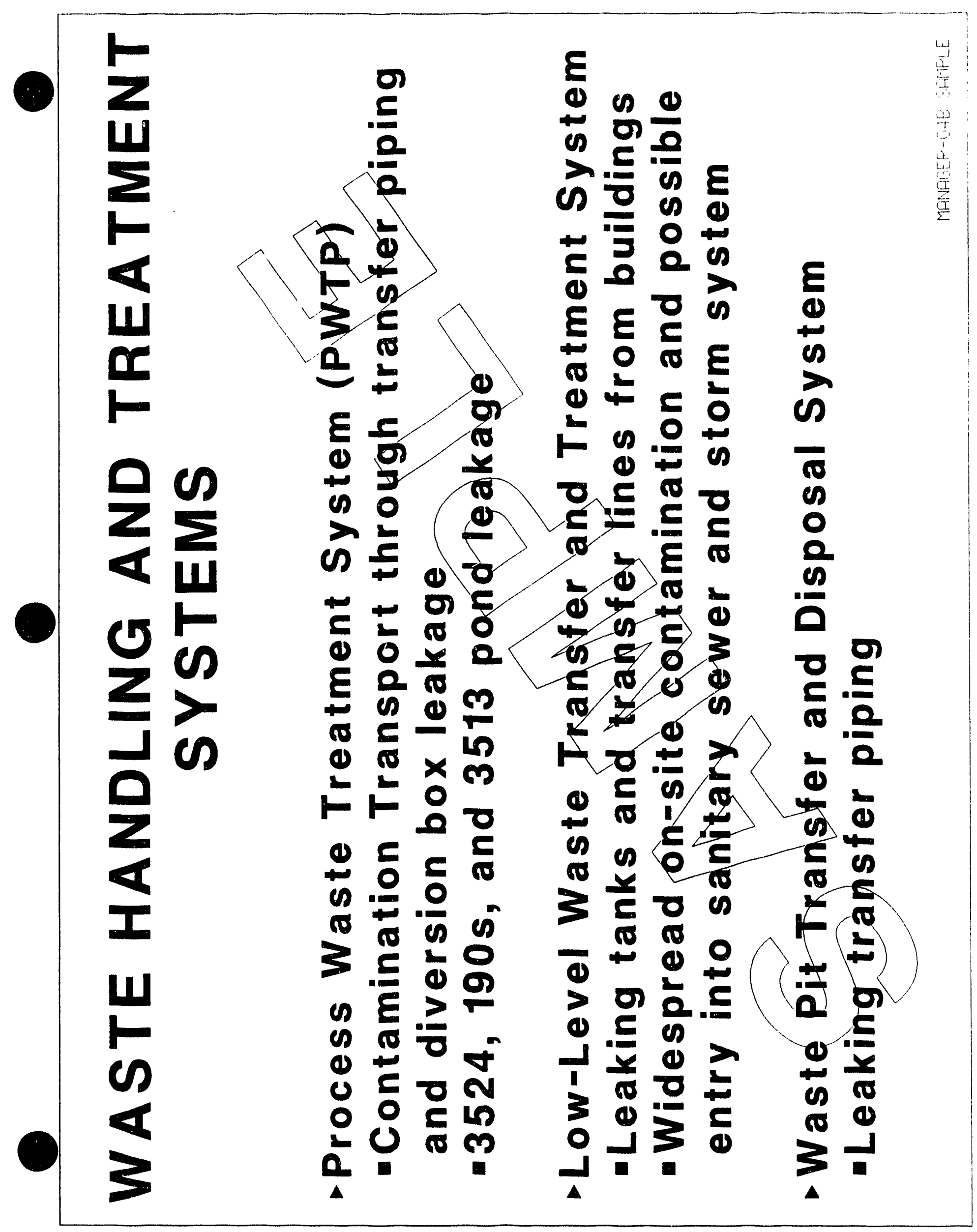




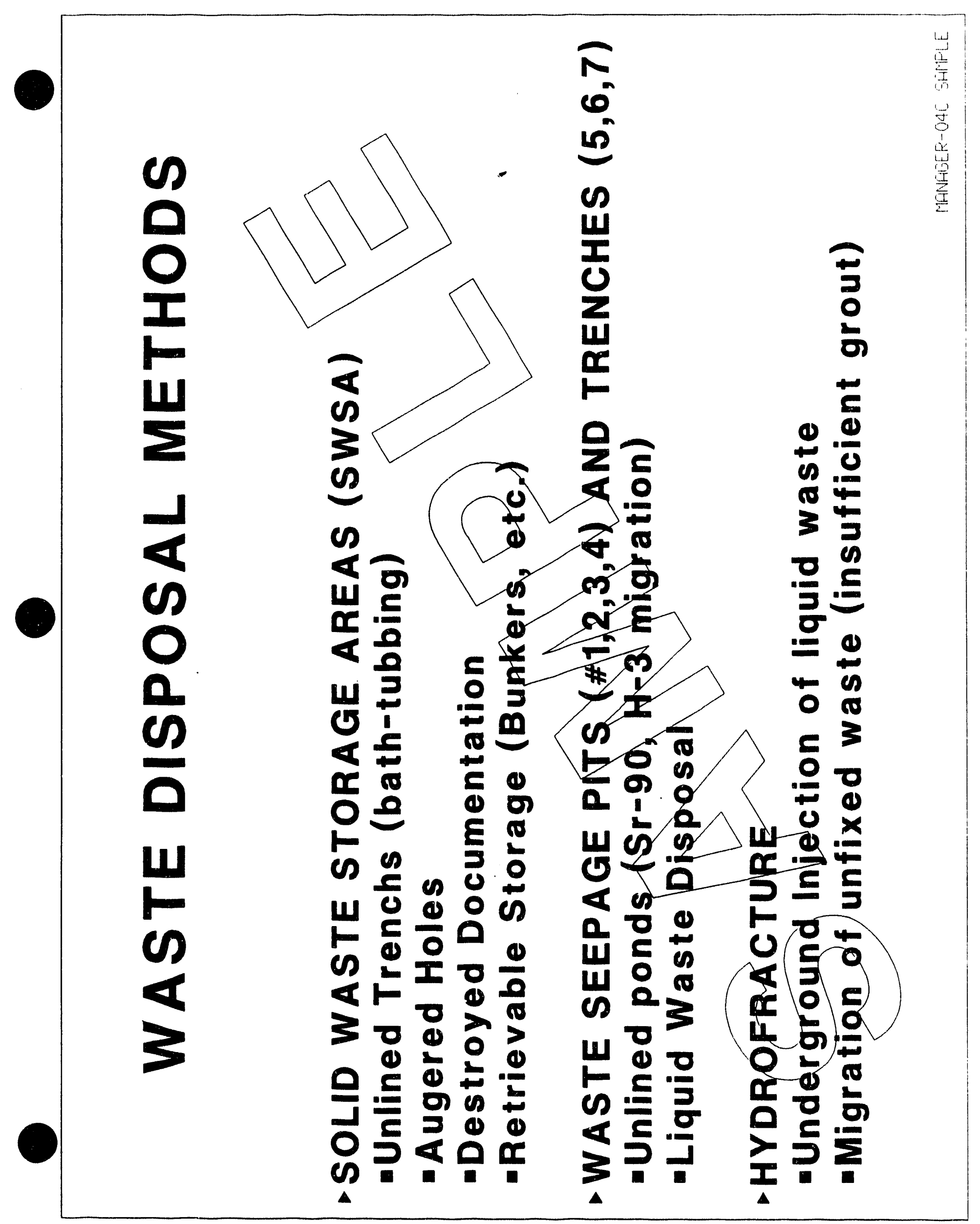

I-15 


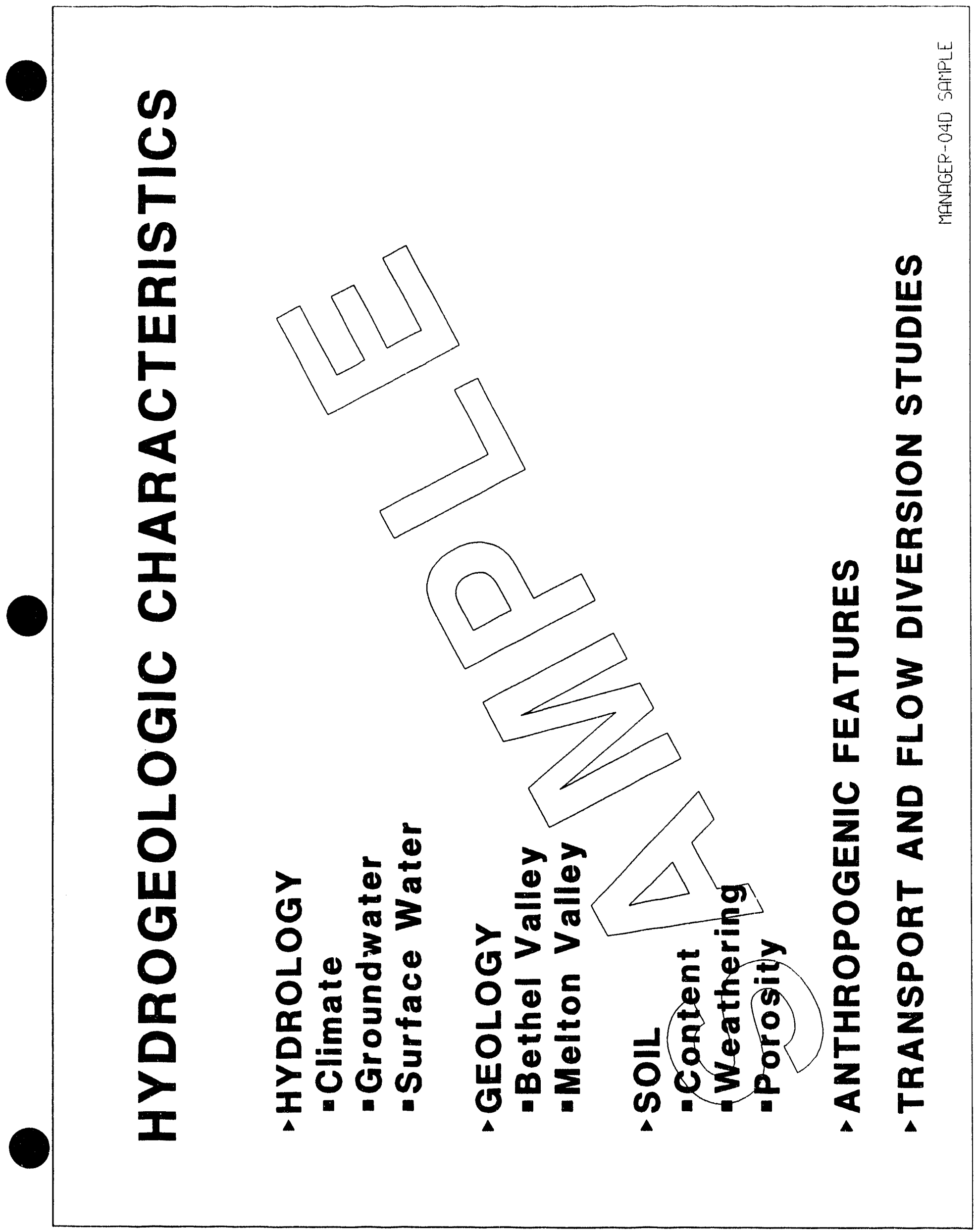




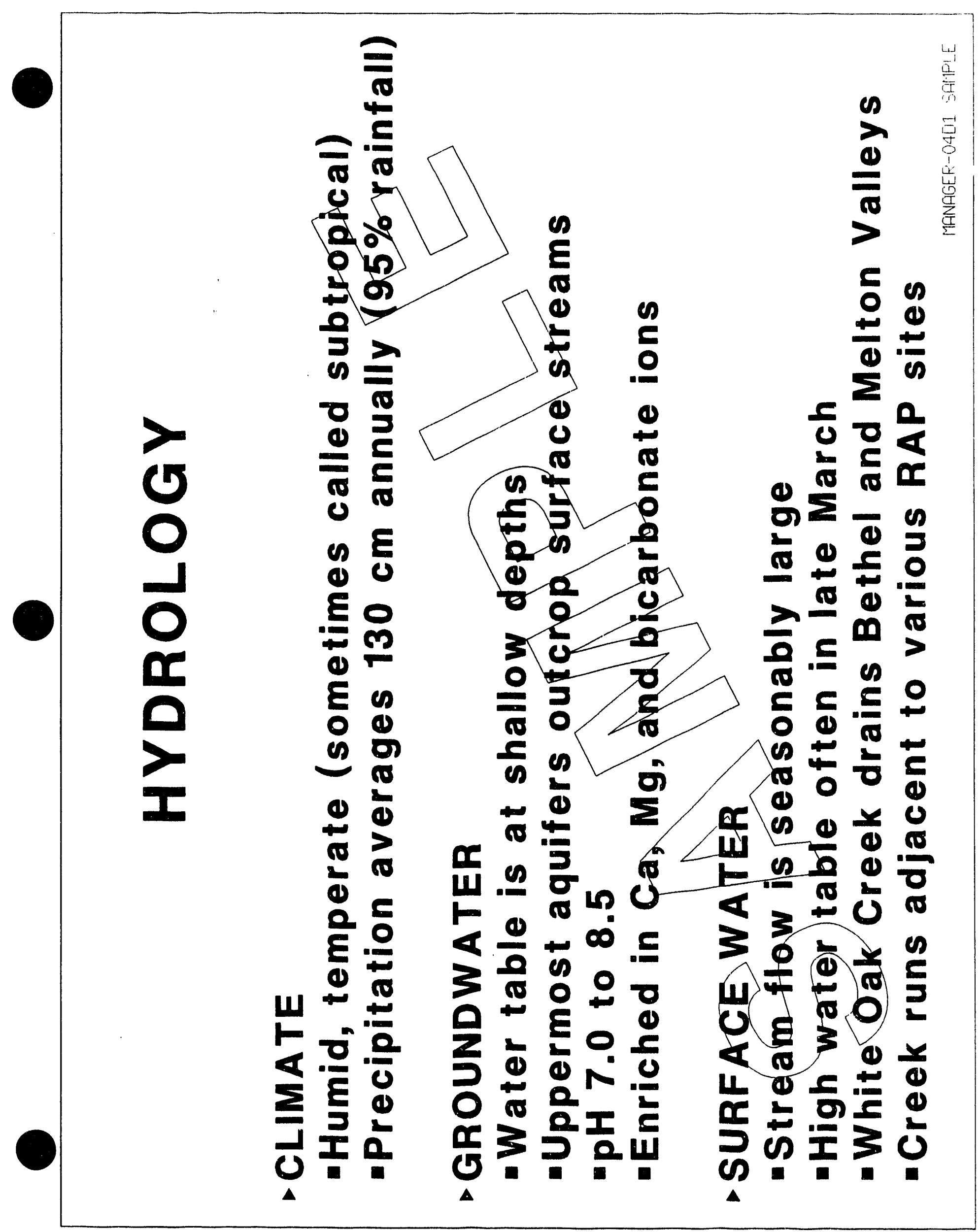




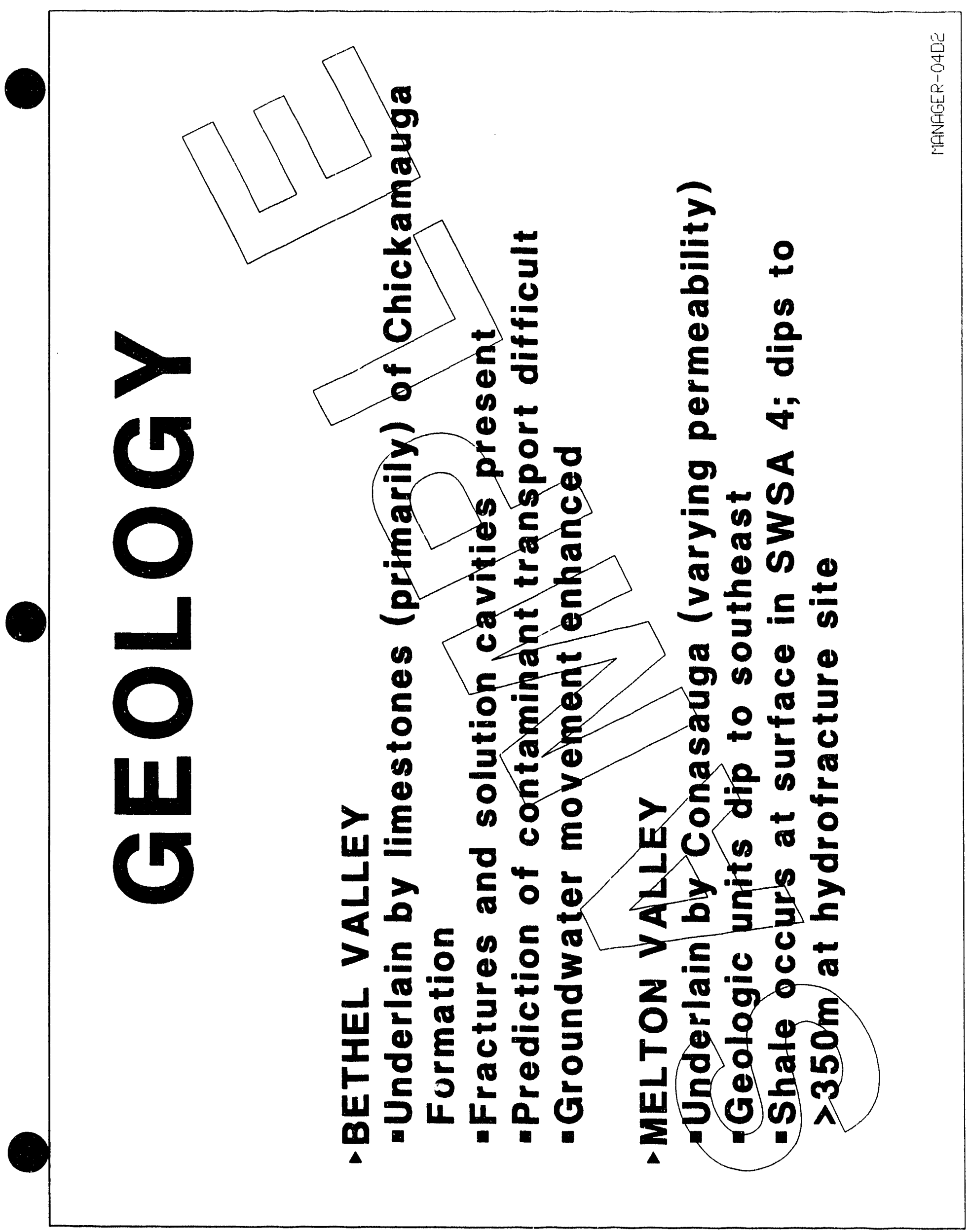

$I-18$ 


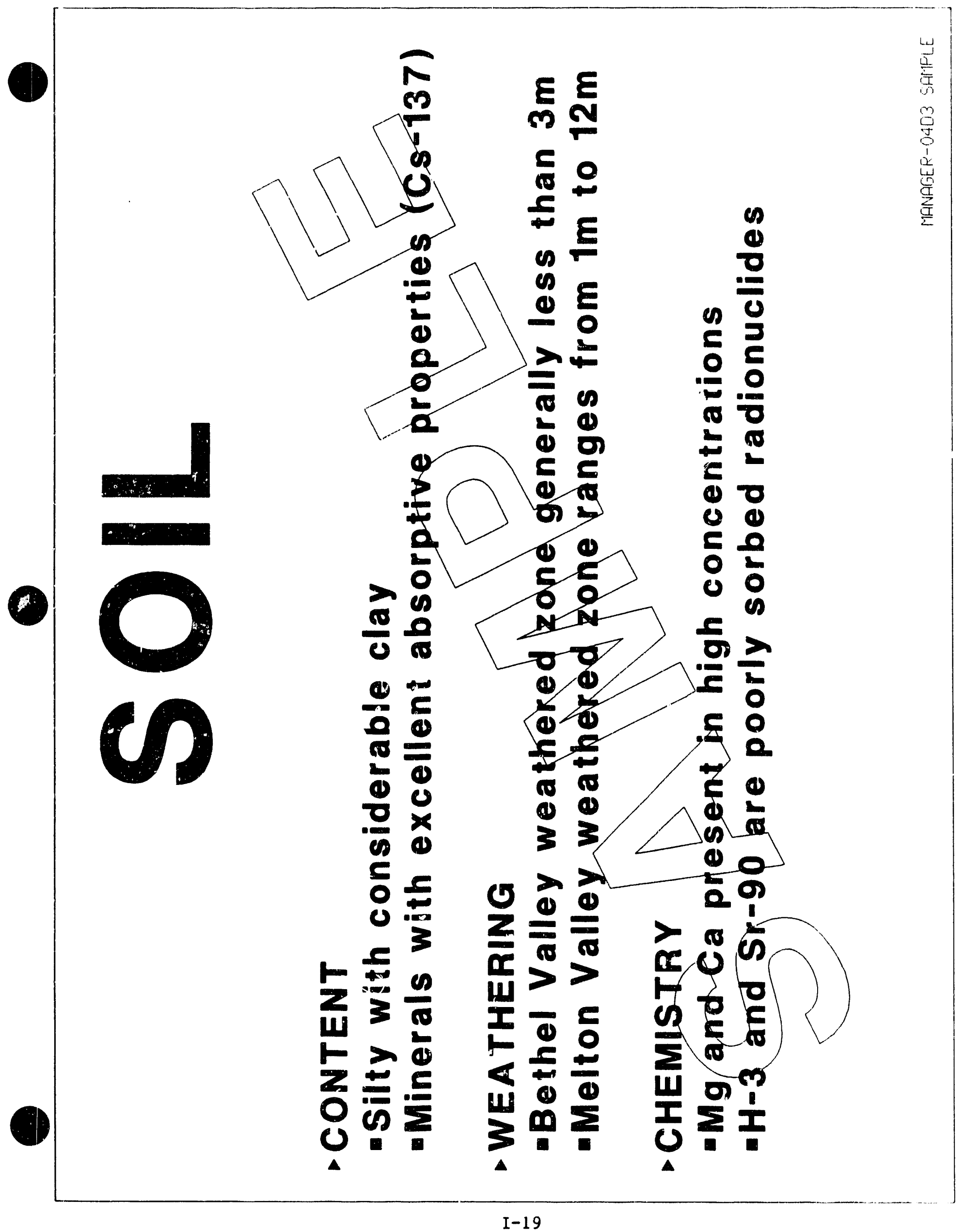

TRADE SARA/OSHA Training: March 1989 


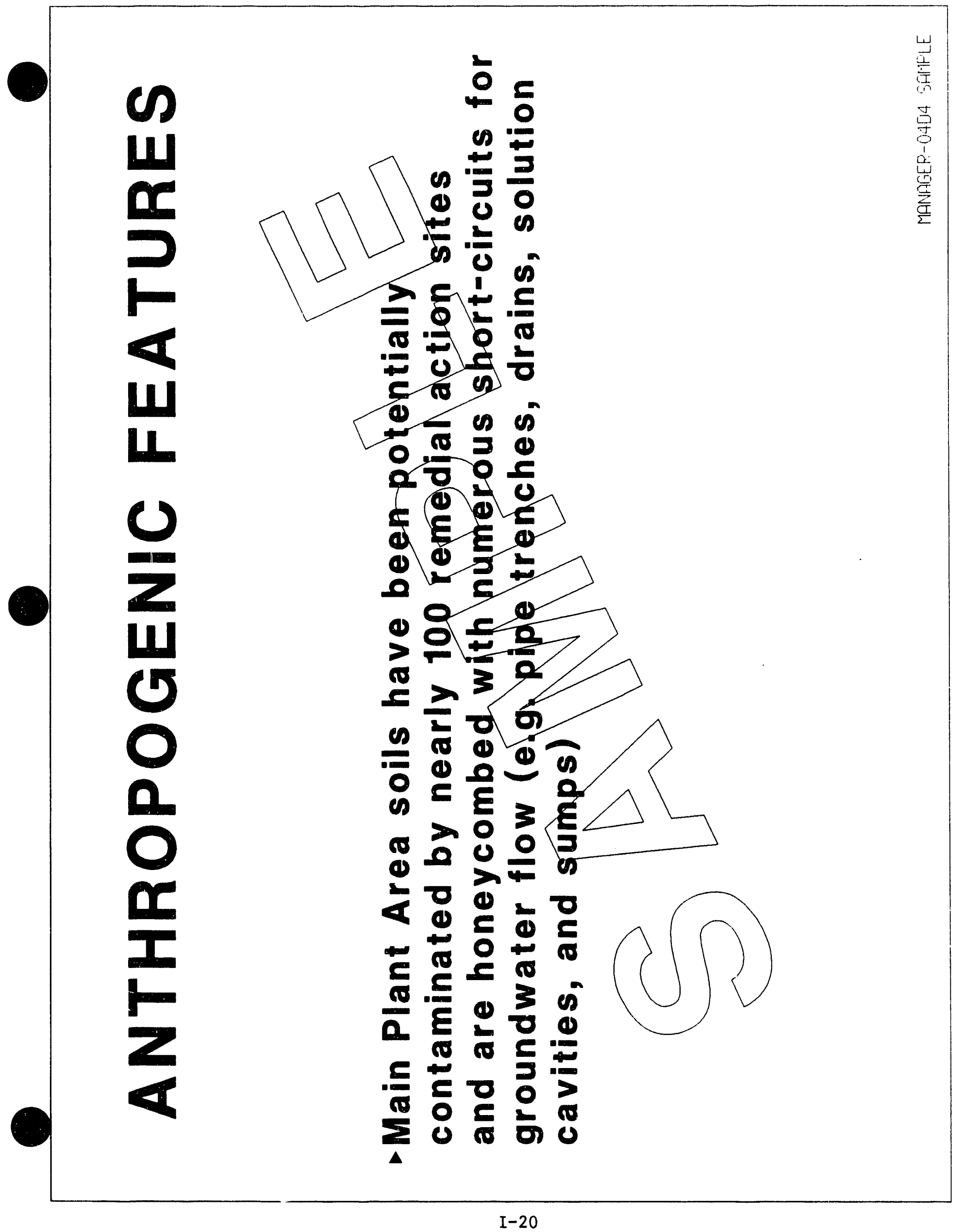

TRADE SARA/OSHA Training: March 1989 


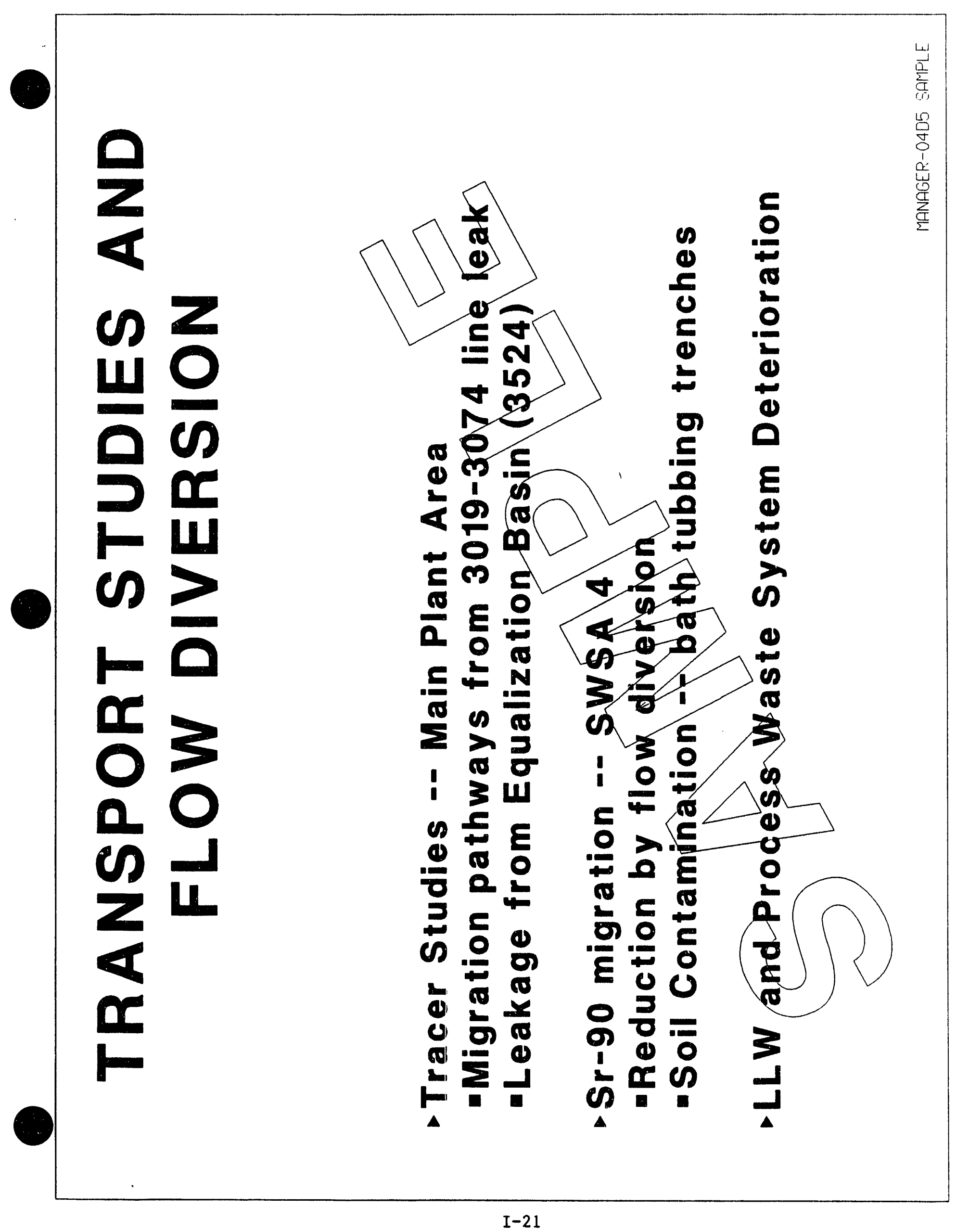




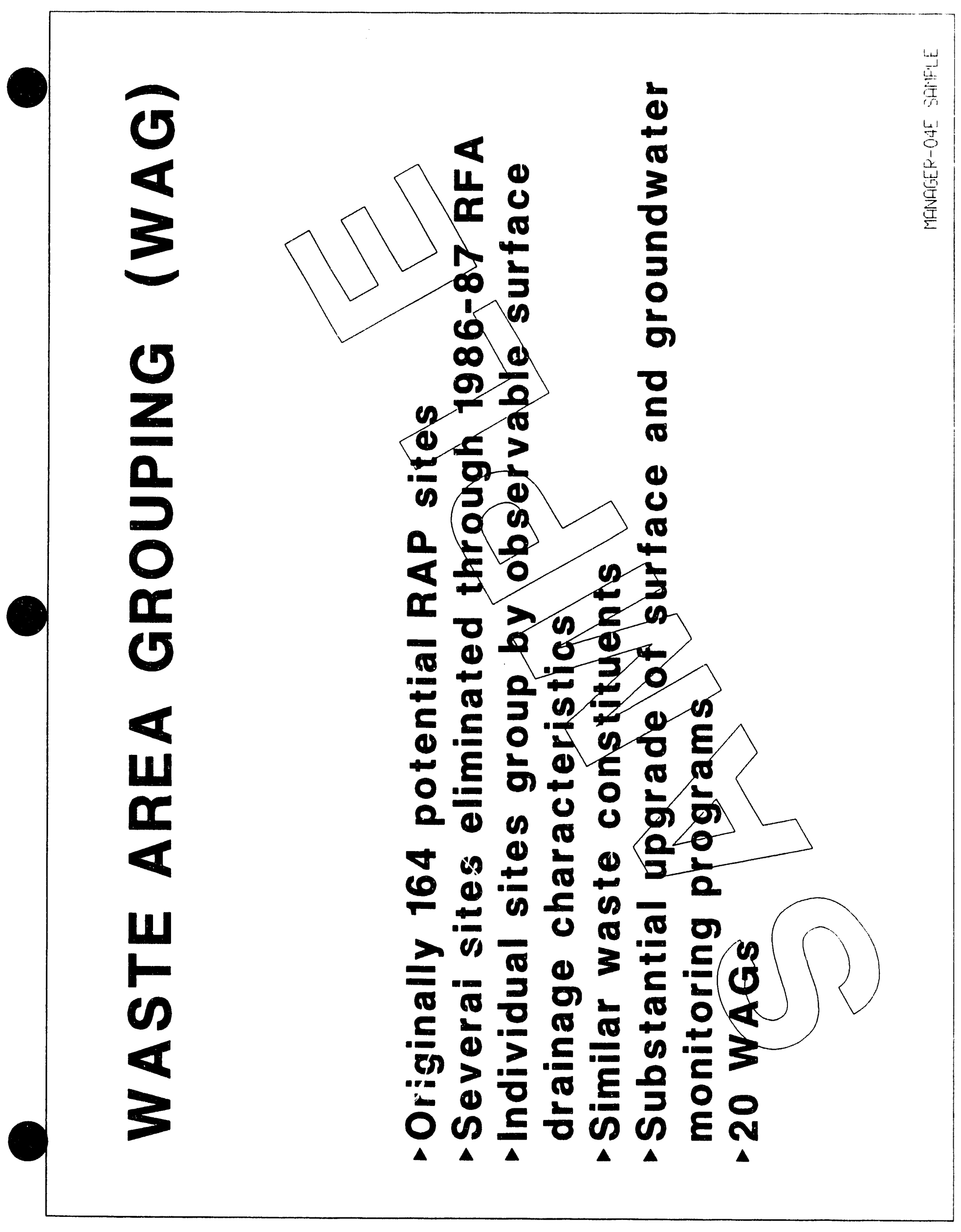

$\mathrm{I}-22$

TRADE SARA/OSHA Tralning: March 1989 
$\boldsymbol{\omega}$

«

U

$\boldsymbol{\alpha}$

0

1

UI

E.

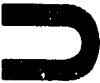

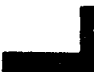

11

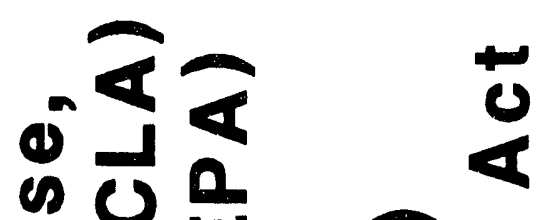

a

일 《

핀 00

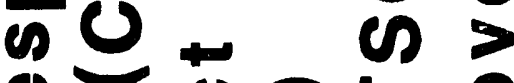

C 0210

I $\div<<-0$

$-0>3+0$

$\square$

8

4

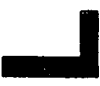

$\infty$

(a)

II

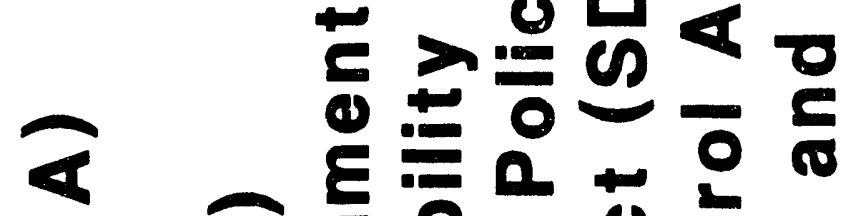

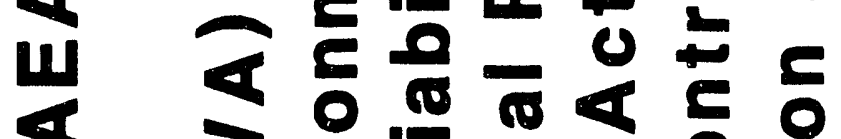

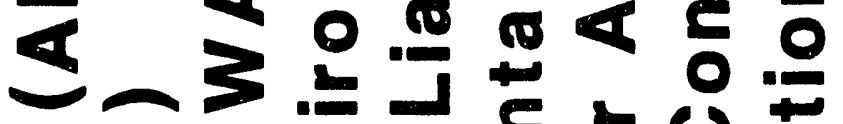

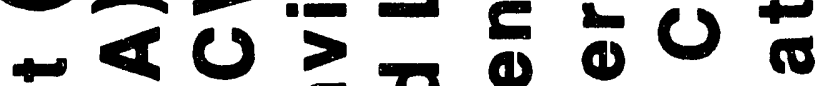

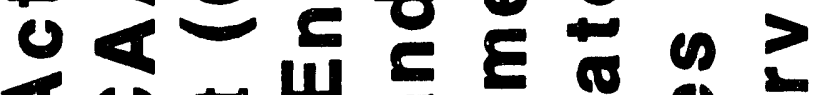

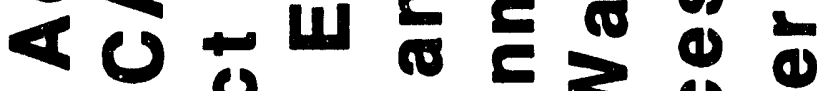

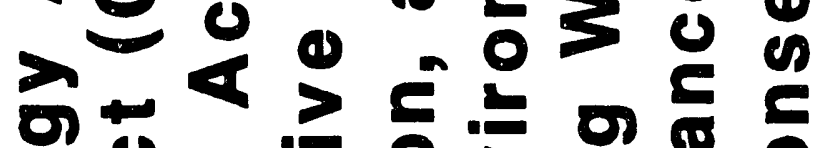

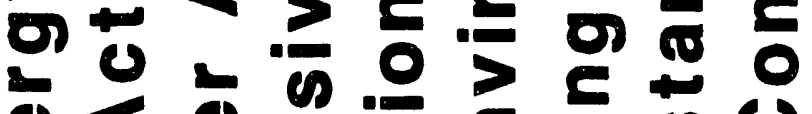

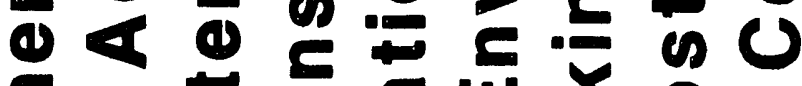

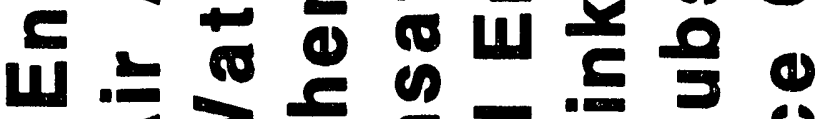

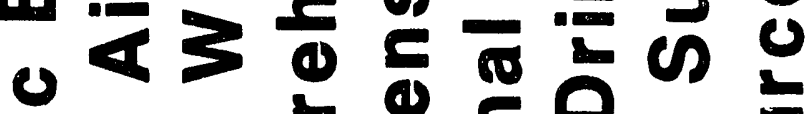

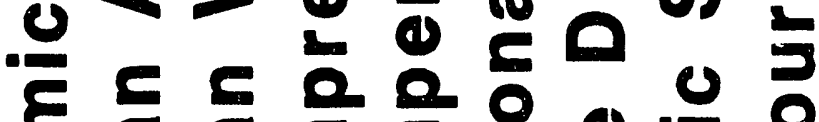

Q⿻

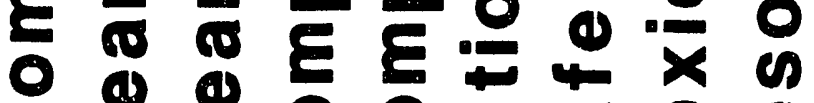

+2000 is 00 1

- 000020 on

$$
\Delta \Delta \Delta \Delta \Delta \Delta \Delta
$$




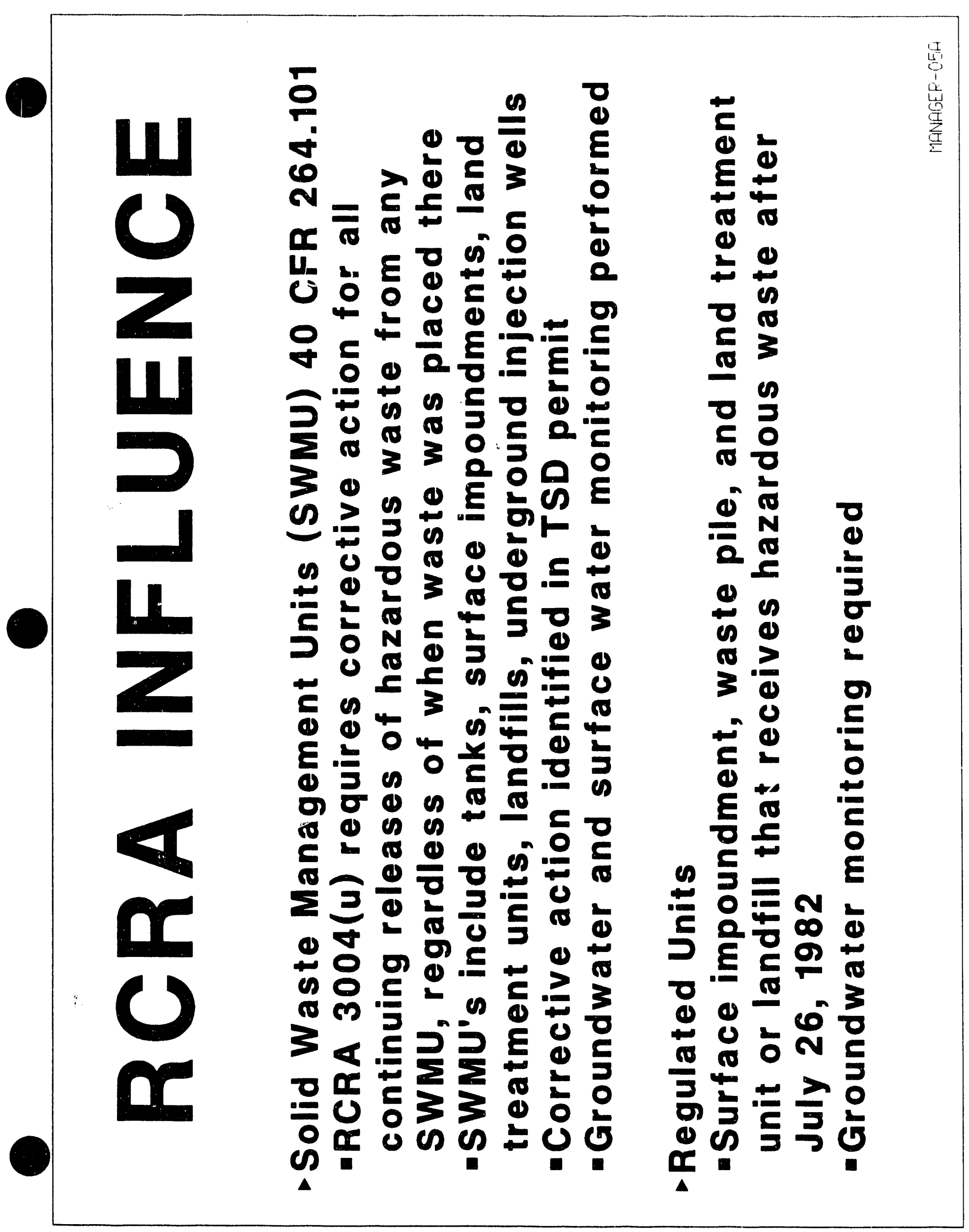




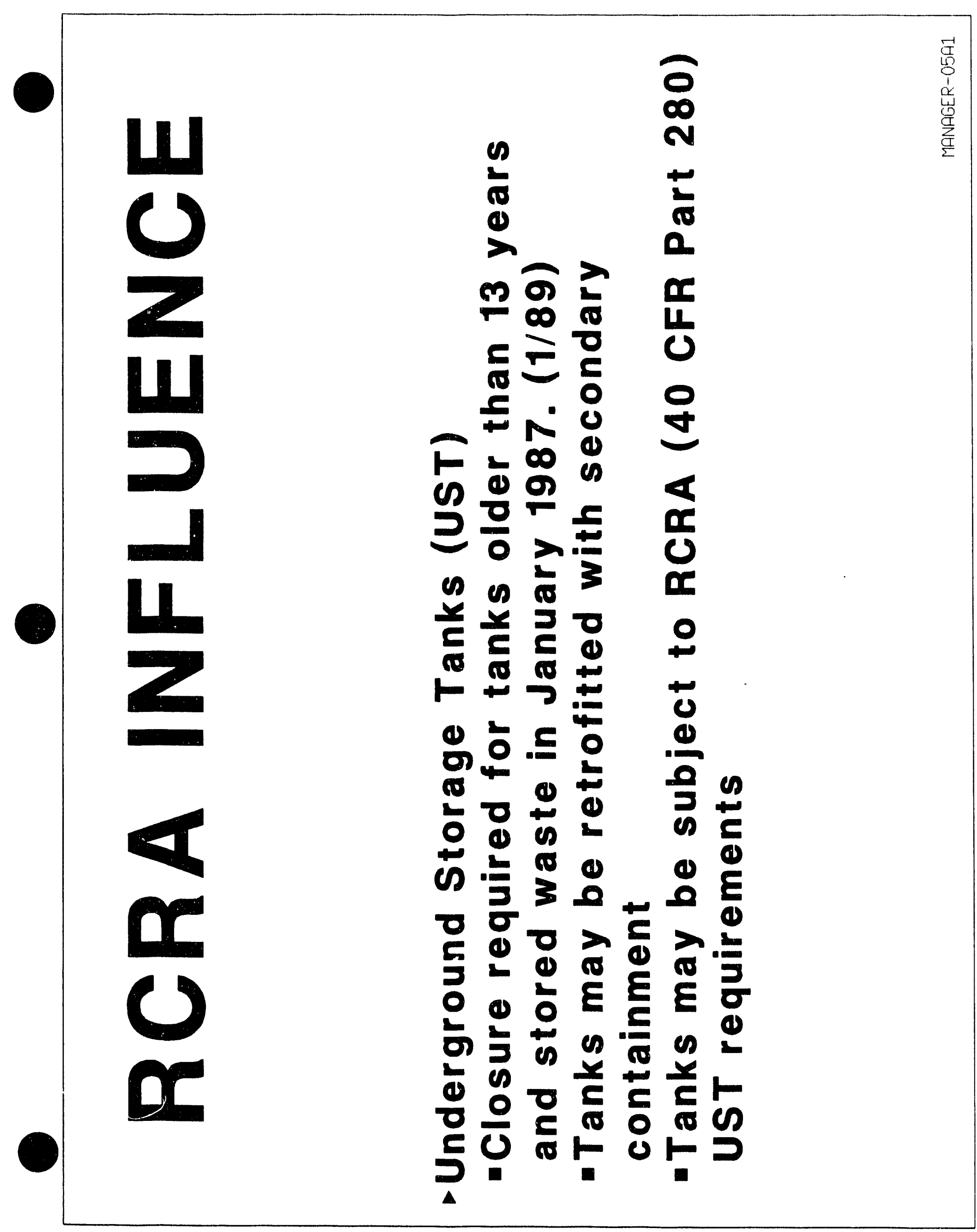

$$
\text { I }-25
$$

TRADE SARA/OSHA Training: March 1989 


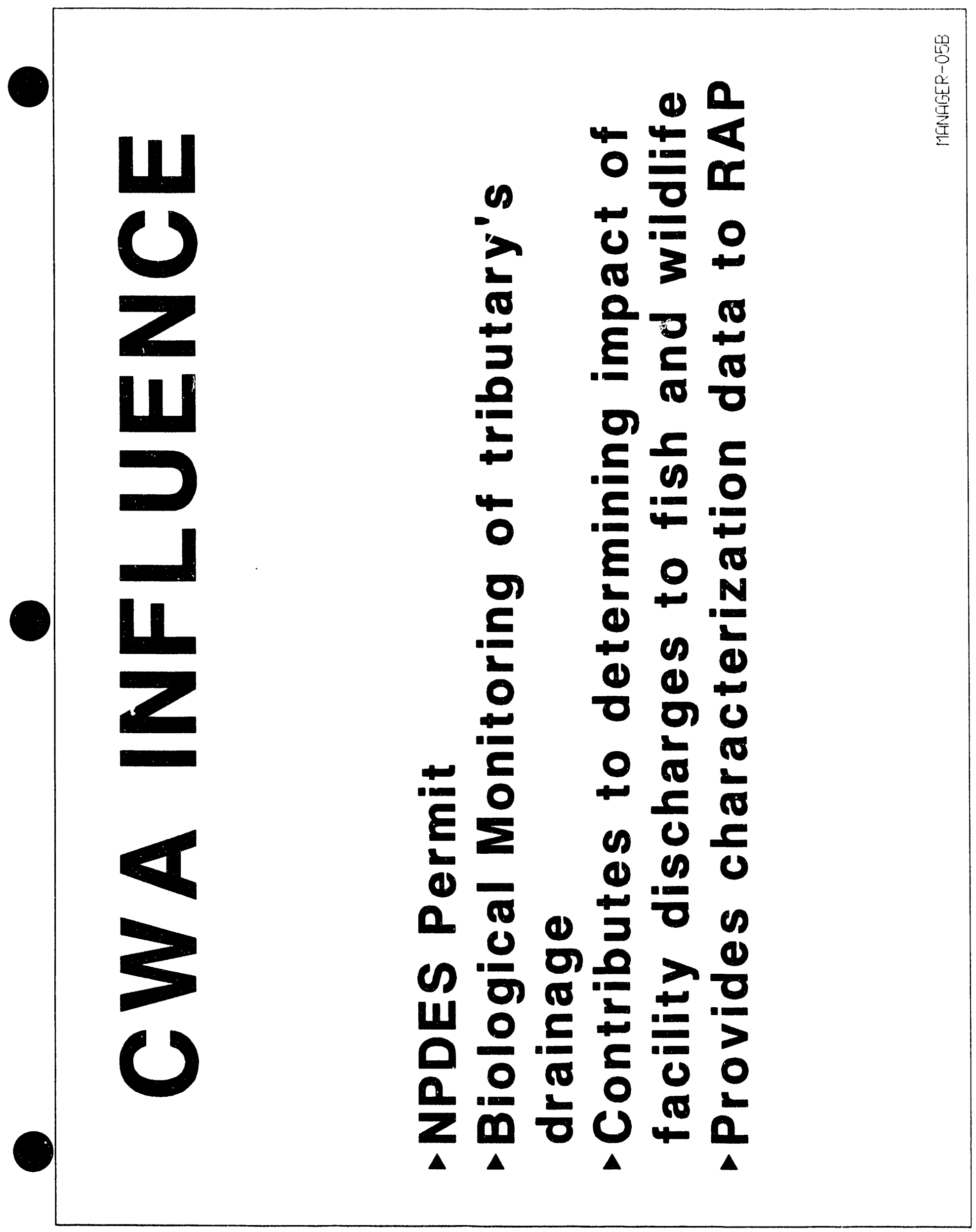




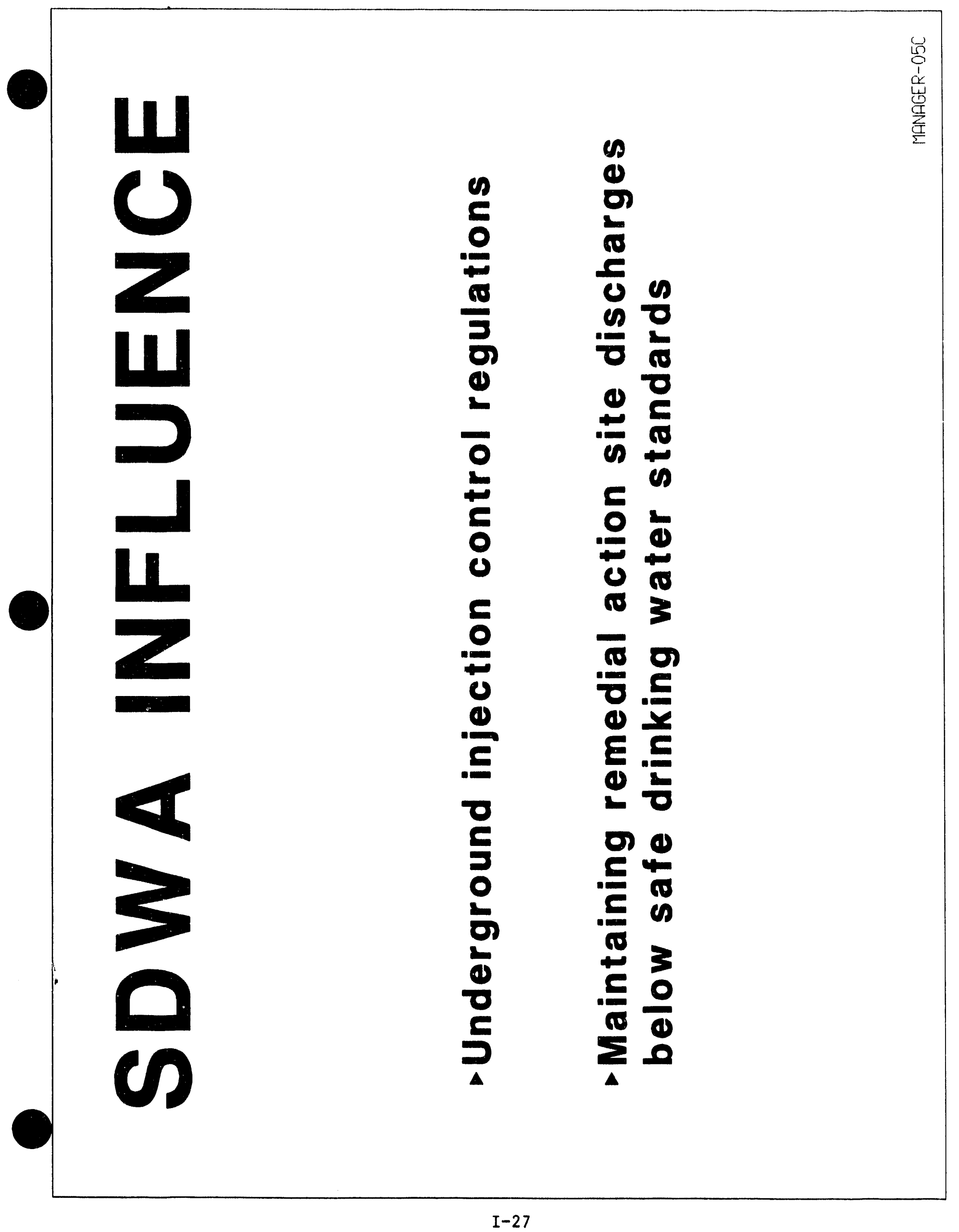

TRADE SARA/OSHA Training: March 1989 


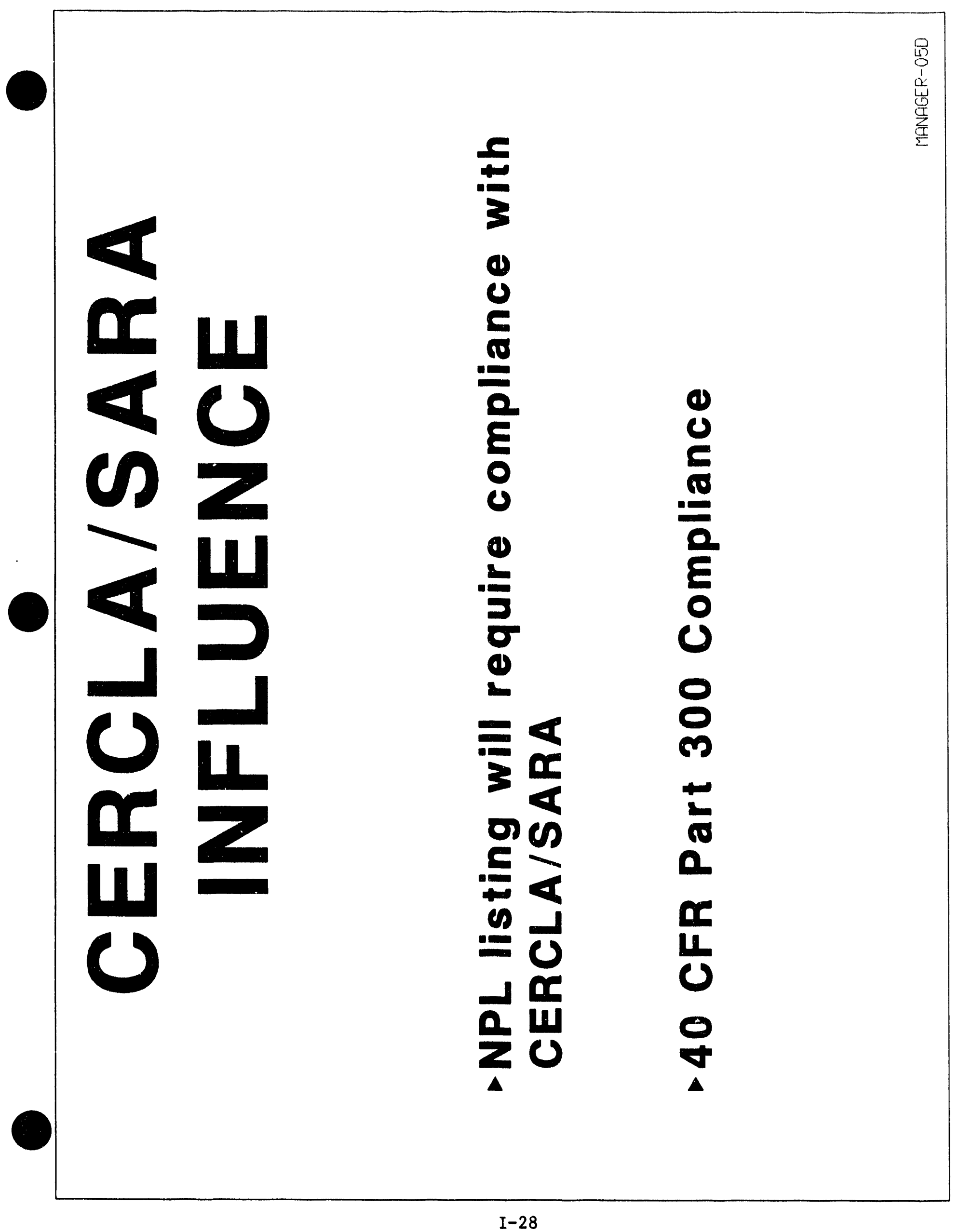

TRADE SARA/OSHA Training: March 1989 


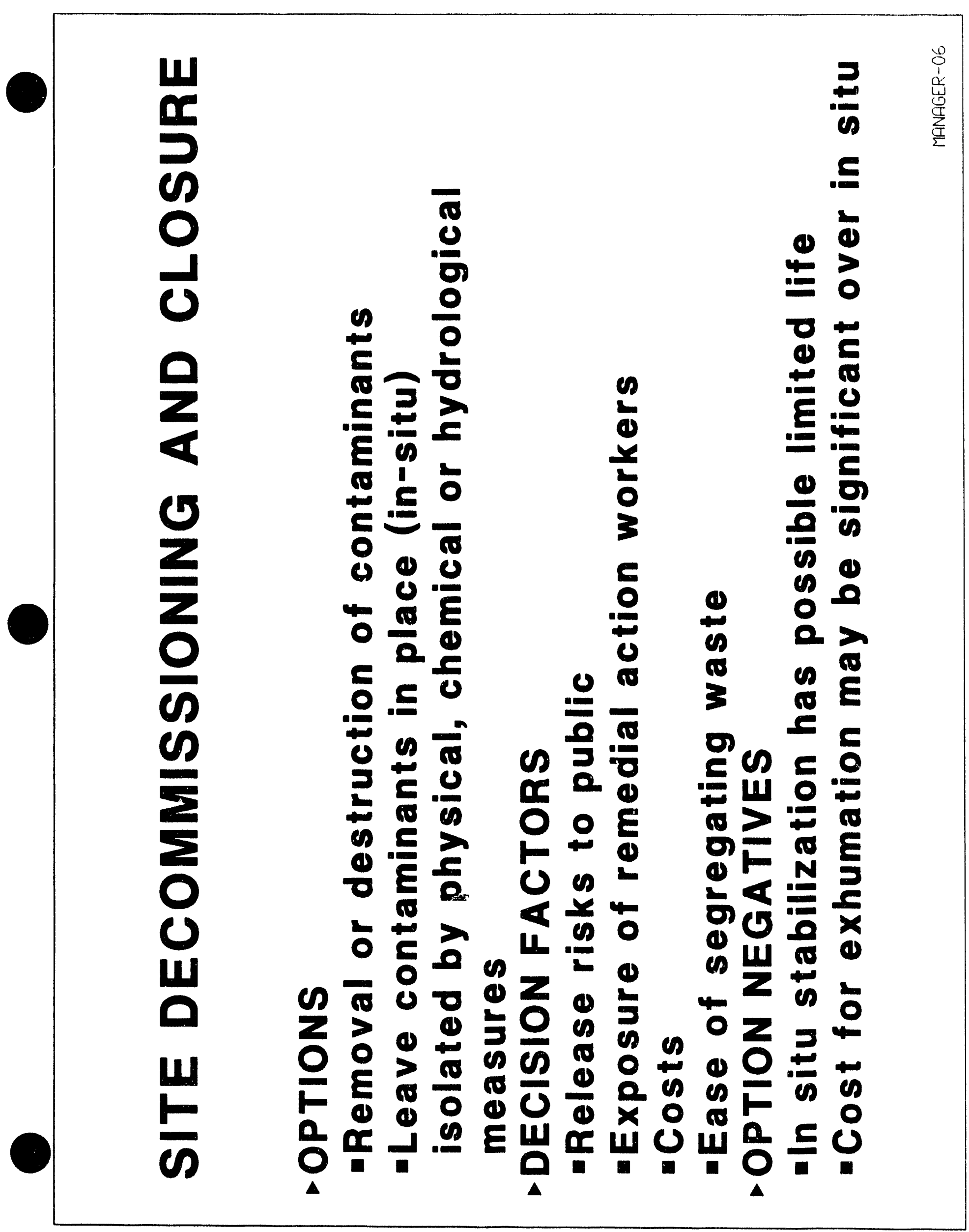

I-29

TRADE SARA/OSHA Training: March 1989 


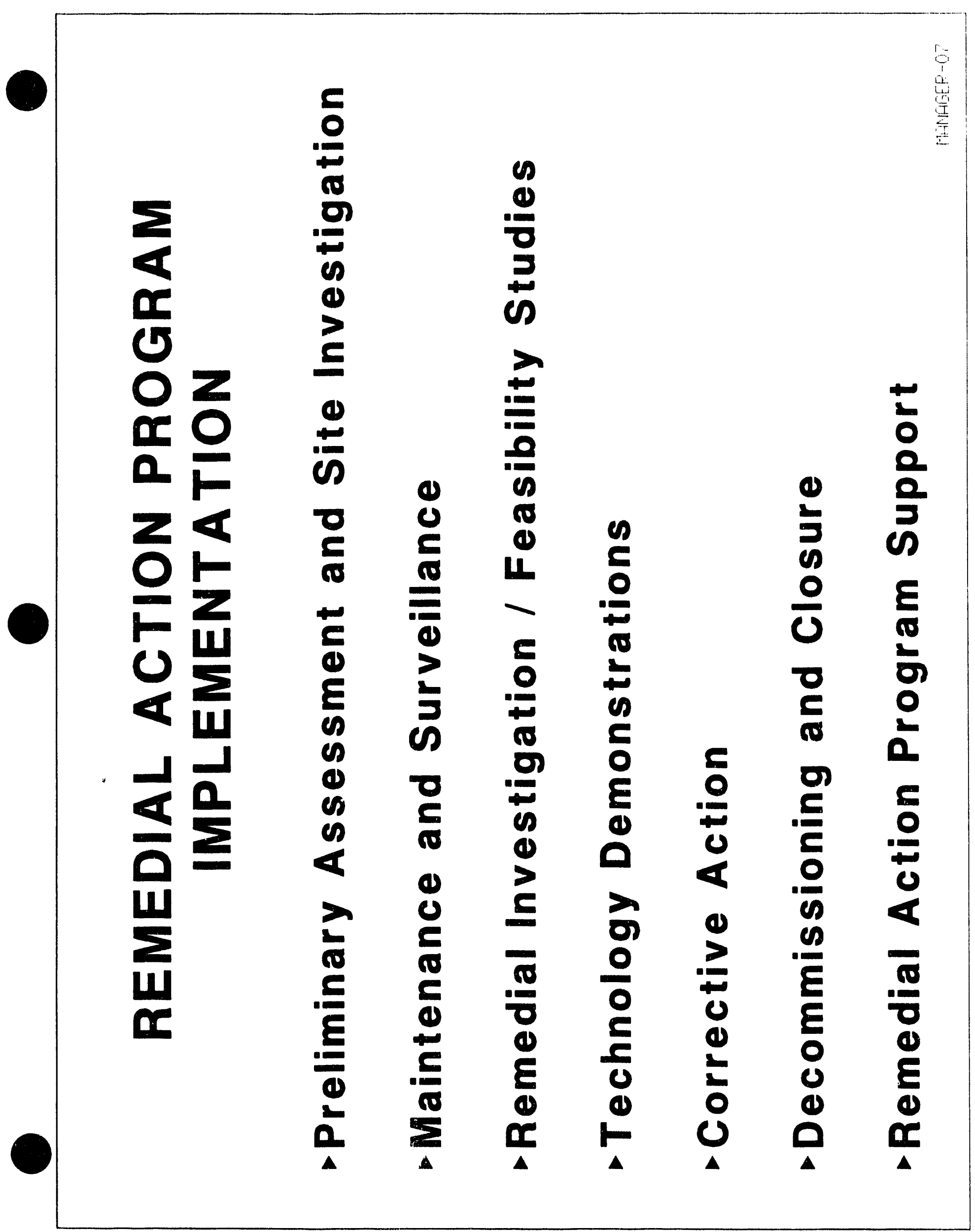

I-30

TRADE SARA/OSHA Train1ng: March 1989 
SCOPE

HANDLING THE PRESS

This module presents guidelines for those managers and supervisors who, by the nature of their involvement in hazardous waste site activities, may find themselves in an interview situation with the press and other communications media. (Suggested time - 45 minutes)

\section{PARTICIPANT GOALS}

1) Identify your facility's public information or media policy and staff.

2) Discuss the media's interest in hazardous waste site operations and activities and the need to be prepared for interview situations.

3) Identify techniques for setting up, participating in, and following up on media interviews.

4) Identify the ideal spokesperson characteristics that are conducive to effective communication.

5) List the five most frequent causes of interview fallures. 


\section{INSTRUCTOR PREPARATION}

1. If possible, recruit a member of the installation public information or public affairs staff to lead or assist with the module.

2. Obtain any guidelines or policies for contact with the media from your facility's public information office.

3. Prepare a list of names, departments, and telephone numbers of contacts at your facility for information about interaction with the media.

4. Collect current news articles about specific installations or DOE facilities and hazardous waste operations or related activities.

5. Prepare handout.

6. Prepare lecture notes. 


\section{INSTROCTIONAL ACTIVIEIES}

1. Explain why the media are likely to be interested in hazardous waste site operations and activities at the installation. Use current news articles about specific installations or DOE facilities in general to introduce the need to be able to communicate with the press and other media.

(PRESS 01)

2. Review the learning objectives.

3. Discuss your facility's public information policy.

4. Discuss whom to contact at your facility for information about interaction with the media.

5. Review guidelines for what spokespersons should do before agreeing to an interview.

6. Ask the participants how they would prepare for an interview or news conference. Discuss the steps outlined in the handout for obtaining and developing the information to be used: accuracy, candor, appropriatencss, 1ikely questions, key points/messages, practice, and evaluation. Ask for good and bad examples from participants.

7. Review guidelines for dealing with the media before an interview.

8. Discuss the techniques used to communicate effectively during the interview and how they relate to the overall message being conveyed.

9. Identify steps for concluding the interview and following up after the interview.

10. :iummarize ty asking participants to name the characteristics of ideal spokespersot,s: common sense, stamina, composure and tact, seniority in organization, knowledge and credibility, and ability to translate technical information effectively into layman's terms.

11. Close with the five most frequent interview failures:

* Failure to take charge

*Failure to anticipate questions

*Failure to develop key messages

*Failure to stick to the facts

*Failure to stay calm 
SARA/OSHA Training for Managers and Supervisors

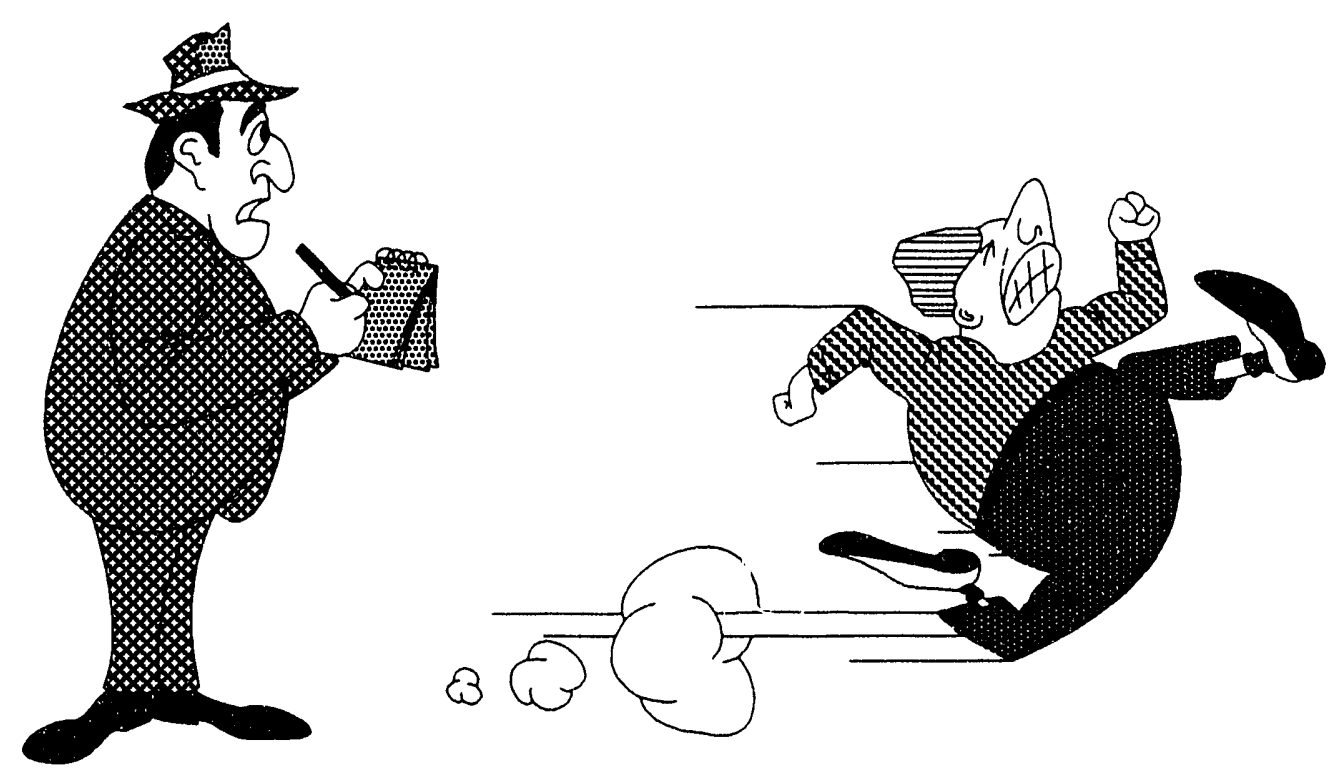

Handling

the

Press and the Media

\author{
Guidelines \\ for \\ Spokespersons
}


Handling the Press and the Media

Guidelines for Spokespersons

\section{OBJECTIVES}

- To discuss the media's interest in hazardous waste site operations and activities, and the need to be prepared for interview situations.

- To identify techniques for setting up, participating in, and following up on media interviews.

- To identify those characteristics of an ideal spokesperson that are conducive to effective communication.

- To list five most frequent causes of interview failures. 


\section{Handling the Press and the Media}

\section{Guidelines for Spokespersons}

\section{BEFORE YOU AGREE TO AN INTERVIEW:}

1. Ask who will be asking the questions.

Indicate no preference for a particular reporter.

2. Ask what topics the reporter will want to cover.

Do not ask for specific questions in advance.

3. Caution the news organization that you are not the right person to interview if there are topics you cannot discuss.

Do not insist that the reporter not ask about certain subjects.

4. Ask how long the interview will be and what the format will be.

5. Ask who else will be interviewed.

Do not insist that the reporter not interview an adversary. 


\section{Handling the Press and the Media}

\section{Guidelines for Spokespersons}

\section{PRIOR TO INTERVIEW/NEWS CONFERENCE:}

1. Obtain accurate information and be completely honest.

2. Decide what information is appropriate.

3. Review subjects you do not want to address.

4. Prepare for likely questions.

5. Organize information into key points and key messages.

6. PRACTICE using non-technical people as your audience.

7. Critique practice sessions and revise your approach as needed.

\section{DO NOT:}

- Try to fool the reporters and the public.

- Believe you know it all.

- Figure you can wing it.

- Expect to evade all tough questions. 


\section{Handling the Press and the Media}

\section{Guidelines for Spokespersons}

\section{AFTER PRESS ARRIVES, BEFORE THE INTERVIEW:}

1. Assume that everything is on the record.

2. Review with reporters topics you cannot comment on (if appropriate and specified in advance).

3. Offer to obtain additional information for the reporters so that you can gauge their interests.

4. Stress your interest in getting accurate information for reporters.

5. Be cordial and professional. 


\section{Handling the Press and the Media}

\section{Guldelines for Spokespersons}

\section{DURING THE INTERVIEW:}

1. Be honest and accurate.

2. Stick to your key points.

3. Take charge and lead the interview.

4. Do not dwell on negative allegations; raise your key messages.

5. Do not be afraid to say you don't know the answer.

6. Offer to find out information you don't have and provide it later if a question is raised about it.

7. Explain the subject, keeping explanations simple, factual, non-technical.

8. Give a reason if you can't talk about a subject: do not dismiss a question with "No comment".

9. Correct big mistakes by stating that you didn't give an adequate answer and you would like a chance to clear up the confusion.

10.State conclusions first; then back them up with facts.

11.Be open and cordial. 


\section{Handling the Press and the Media}

\section{Guidelines for Spokespersons}

\section{AFTER THE INTERVIEW:}

1. Remember what you say is still on the record.

2. Be careful around microphones and tape recorders.

3. Correct any mistakes you made in the interview.

4. Volunteer to get additional information reporters need.

5. Tell reporters to telephone if they have any questions about something you said.

6. Volunteer to be available if a reporter wants to go over it with you.

7. Call reporters if stories appear that are inaccurate, and politely point out what is wrong. 


\section{Handling the Press and the Media}

\section{Guldelines for Spokespersons}

\section{CHARACTERISTICS OF IDEAL SPOKESPERSONS INCLUDE:}

- Common sense

- Stamina

- Composure and Tact

- Seniority in Organization

- Knowledge and Credlbility

- Ability to translate technical information effectively into layman's terms 


\section{Handling the Press and the Media}

\section{Guldellnes for Spokespersons}

\section{FIVE MOST FREQUENT INTERVIEW FAILURES:}

1. Failure to take charge: The spokesperson must be a leader. His/her role is not just there to answer questions, but to disseminate information.

2. Failure to anticipate questions: Don't just concentrate on assembling the factual details. Prepare for obvious questions.

3. Failure to develop key messages: This is your opportunity to communicate with the public. Make sure you can take advantage of it by having your organization's message prepared and ready for use.

4. Failure to stick to the facts: Speculating or answering hypothetical questions can get you in trouble. Avoid "what if" questions by confining your answers to what is known.

5. Failure to keep calm: By not letting questions get under your skin, you will show a willingness to cooperate with courteous journalists and convey an impression of candor. Keep cool. 


\section{SELECTING AND USING PERSONAL PROTECTIVE EQUIPMENT}

This two-part module discusses selection of chemical protective clothing and practical factors that may limit usage of personal protective equipment (PPE) in field situations.

(Suggested time - 1 hour, 20 minutes) 
SELECTING AND USING PERSONAL PROTECTIVE EQUIPMENT

\section{PART I}

SCOPE

Chemical protective clothing is avallable in a variety of materials that offer a range of protection against different chemicals. This section is intended to provide guidance in the complex task of chemical protective clothing selection. It contains a discussion of permeation, degradation, and penetration, which, ideally, a chosen material will resist. Basic concepts of permeation theory and chemical resistance are presented, followed by guidance for permeation data interpretation. The process of selection is discussed, including sources of information on chemical protective clothing to aid in this selection process. Factors such as durability, flexibility, and ease of decontamination, which also must be considered during clothing selection, are summarized.

\section{PARTICIPANT GOALS}

1) Define permeation, degradation, and penetration.

2) Explain the concepts of breakthrough time and permeation rate.

3) List five factors that affect permeation rates and breakthrough times.

4) Explain how clothing thickness, temperature effects, and chemical mixtures present problems in applying permeation data.

5) Learn how to select an appropriate chemical protective clothing material through assessment of the exposure situation, consideration of the toxicity of the chemical, and consultation of permeation literature.

6) Name four sources of information on personal protective clothing.

7) Explain the limitations of vendor literature in personal protective clothing selection.

8) Identify four factors to be considered in protective clothing selection that affect the ability of the worker to perform the required task. 
SELECTING AND USING PERSONAL PROTECTIVE EQUIPMENT

\section{PART II}

SCOPE

Topics related to the use of personal protective equipment (PPE) from a management standpoint are considered in this portion of the module. Before workers actually begin work in their PPE, the anticipated duration of the work mission should be established. Several factors that limit mission length are discussed. Also, because wearing PPE puts a hazardous waste worker at considerable risk of developing heat stress, factors contributing to heat stress are reviewed along with appropriate management steps toward prevention. Finally, the individual human characteristics that play a factor in decreased worker performance with PPE use are discussed. Some of the precautionary and training measures that need to be taken to avoid infury indured by PPE are identified.

\section{PARTICIPANT GOALS}

1) Identify four factors that may limit the duration of a work mission.

2) List five factors that may predispose someone to heat stress.

3) Explain three ways to monitor a worker for heat stress.

4) Identify four of the six actions that management can take to avoid heat stress.

5) Name six human factors affecting worker ability to function using personal protective equipment.

6) Explain three physical characteristics a fit person will have relative to an unfit person in performing a given level of work.

7) Explain the concept of acclimatization in terms of three physiological responses to work activity.

8) Discuss fluid intake to prevent dehydration.

TRADE SARA/OSHA Training: March 1989 


\section{INSTROCTOR PREPARATION}

1. Assemble viewgraphs.

2. Prepare lecture notes.

3. Prepare a handout of information on personal protective clothing. The handout used by ORNL is included as pages III-8 through III-10. 


\section{INSTRUCTIONAL ACTIVITIES}

1. Introduce the subject and explain that this module is divided into two parts; personal protective equipment and physiological factors with impacts on PPE use. (PPESEL 32A)

A. SELECTING PERSONAL PROTECTIVE EQUIPMENT

1. Discuss the objectives of Part I. (PPESEL 33)

2. Discuss how no single material protects against all chemicals or exposure situations. (PPESEL 15)

3. Explain that the material chosen for PPE should resist permeation, degradation, and penetration. (PPESEL 13)

4. Describe the three-step process of permeation. (PPESEL 27)

5. Describe how to plot permeation test results as concentration over time.

(PPESEL 18: Note: this was on a flipchart for ORNL's presentation)

6. Discuss the problems that can arise in interpreting permeation data. (PPESEL 28)

7. Describe the factors that cause permeation rates and breakthrough times to vary.

(PPESEL 16)

8. Discuss the factors affecting the comparison of permeation results. (PPESEL 29)

9. Describe problerus that may occur when applying permeation data. (PPESEL 30)

10. Discuss the PPE selection process, including assessment of exposure situations, toxicity of the chemicals, and how to use permeation literature.

(PPESEL 31) 
11. Discuss the different types of information sources for personal protective equipment, using the participant handout "Sources of Information on Chemical Protective Clothing."

(PPESEL 14)

12. Explain that caution should be taken in reviewing vendor literature because of limitations on ine data provided.

(PPESEL 17)

13. Describe other considerations in selecting PPE such as durability, flexibility, temperature effects, ease of decontamination, compatibility with other equipment, and duration of use.

(PPESEL 19)

14. Describe some special conditions that may affect PPE choice or performance.

(PPESEL 20)

B. USING PERSONAL PROTECTIVE EQUIPMENT

1. Review Part II objectives.

(PPESEL 34)

2. Describe such work mission duration factors as air supply consumption, PPE permeation, penetration rate, ambient temperature, and coolant supply.

(PPESEL 01)

3. Describe the variables to be considered in air supply consumption. (PPESEL 02)

4. Discuss the causes of suit/ensemble permeation and penetration. (PPESEL 03)

5. Describe how ambient temperatures affect personal protective equipment. (PPESEL 04)

6. Explain the factors that affect coolant supply effectiveness. (PPESEL 05)

7. Introduce heat stress and other physiological factors.

(PPESEL 21)

TRADE SARA/OSHA Training: March 1989 
8. Describe the factors that predispose an individual to heat stress. (PPESEL 22)

9. Discuss how to establish safe work/rest periods. (PPESEL 23)

10. Discuss the ways in which workers should be monitored for heat stress while they are wearing permeable, semipermeable, or impermeable clothing.

(PPESEL 24)

11. Describe how to monitor a worker for heat stress by measuring heart rate, oral temperature, and body water loss. (PPESEL 25)

12. Discuss the s,teps management should take to avoid heat stress. (PPESEL 26)

13. Describe the human factors that affect the worker's ability to function while using PPE. (PPESEL 06)

14. Describe the physical condition factors distinguishing a fit person from an unfit one. (PPESEL 07)

15. Describe the physical advantages of acclimatization. (PPESEL 08)

16. Define dehydration; explain its side effects and ways to prevent it. (PPESEL 10)

17. Describe the effects of age on the tolerance of heat. (PPESEL 09)

18. Explain the effect of gender on work capacity. (PPESEL 11)

19. Explain the relationship of weight to heat production and the special needs of overweight individuals in heat stress situations. (PPESEL 12)

20. Review the objectives of Parts I and II. (PPESEL 33 and 34) 


\section{SOURCES OF INFORMATION ON CHEMICAL}

PROTECTIVE CLOTHING (CPC)

\section{A. INDUSTRY}

By far the best source for information on CPC is the CPC vendors. The large, full-1ine vendors and the specialty products manufacturers generally have tested their products against a wide range of chemicals. Furthermore, they have years of experience with their products and typically have a very good understanding of the products' capabilities and limitations.

A second source of information is the chemical manufacturers. These organizations provide clothing for their workers and often conduct their own analysis of protective clothing performance for their chemical products.

\section{B. GOVERNMENT}

Principal sources of CPC information within federal government agencies are:

EPA, Office of Occupational Health and Safety, Room 3503, Waterside Mal1, 401 M Street, S.W., Washington, DC 20460. Telephone 202-382-3647 (David Weitzman).

Federal Emergency Management Agency (FEMA) United States Fire Administration, Office of Firefighter Health and Safety, 16825 South Seton Avenue, Emmitsburg, MD 21727. Telephone 301-447-1182 (Robert McCarthy).

NIOSH, Division of Safety Research, Testing and Criteria Branch, ASI Section, 944 Chestnut Ridge Road, Morgantown, WV 26505. Telephone 304-291-4339 (Stephen Berardine11i).

OSHA, Technical Assistance, Room N3657, 200 Constitution Avenue, NW Washington, DC 20210. Telephone 202-523-7505 (Ching Bien).

U.S. Coast Guard - Headquarters, Office of Research and Development, Commandant, G-DMT-3, 2100 Second Street, S.W., Washington, DC 20593. Telephone 202-267-0853 (Lt. Jeffrey Stu1l).

These agencies are involved in the study, development, and utilization of protective clothing. 


\section{PROFESSIONAL ORGANIZATIONS}

In the United States, three professional organizations have committees directly focused on protective clothing. The American Society for Testing and Materials (ASTM) formed Committee F-23 in 1977 for the purpose of developing standard test methods for protective clothing. Subcommittees of F-23 are addressing the chemical resistance of clothing, the physical properties of clothing, clothing classification methods, and the performance of full-body protective ensembles. The committee is composed of industry, government, and general interest members. It meets twice a year and is a forum for discussing protective clothing test methods. In addition, in 1984 and in 1987 Committee F-23 sponsored international symposia on all aspects of protective clothing. Proceedings of the symposia are published by ASTM as Standard Technical Publications. For further information, telephone ASTM headquarters (215-299-5579).

The American Industrial Hygiene Association (AIHA) addresses CPC through its technical committee on Personal Protective Devices (other than respirators). The committee meets once a year in coincidence with the American Industrial Hygiene conference. This week-long conference typically includes one or two sessions devoted to protective clothing. At these sessions, technical papers are presented describing research, evaluation, or use of protective clothing. Information on this and other AIHA activities may be obtained from AIHA headquarters (216-762-7924).

The National Fire Protection Association (NFPA) formed a subcommittee on hazardous chemical protective clothing in 1986. This subcommittee was established under the NFPA Technical Committee on Protective Equipment for Firefighters. The subcommittee is engaged in writing performance-oriented (manufacturing) standards on chemical protective suits for emergency response personnel. Its membership is composed of representatives from users, manufacturers, testing laboratories, and government. [Note added to ACGIH text: Proposed NFPA standards on chemical protective suits are in development. For information, contact Bruce Teele of the NFPA (617-770-3000 ext. 487).]

\section{TECHNICAL LITERATURE}

In recent years, the principal sources of published technical papers and reports on personal protective clothing have been the:

1. American Industrial Hygiene Association Journal, a monthly publication. AIHA, 475 Wolf Ledges Park, Akron, OH 44311-1087. Telephone 216-762-7924.

2. National Technical Information Service (NTIS). Essentially all federal government sponsored studies may be obtained through NTIS. NTIS, U.S. Department of Commerce, 5285 Port Royal Road, Springfield, VA 22161. Telephone 703-487-4650. 
A new journal, Applied Industrial Hygiene, has been started by the American Conference of Governmental Industrial Hygienists (ACGIH), 6500 Glenway Avenue, Bldg. D-7, Cincinnati, $O H$ 45211-4438. Telephone 513-661-7881. Also articles on protective clothing are usually included in the proceedings of the Hazardous Materials Management Conference (Tower Conference Management Company, Wheaton, IL 60187) and the Hazardous Material Spills Conference (Government Industries, Inc., Rockville, MD 20850).

SOURCE: A. D. Schwope, P. P. Costas, J. D. Jackson, and D. J. Weitzman. Guidelines for the Selection of Chemical Protective Clothing, 3rd ed. Cincinnat, $\mathrm{OH}$ : American Conference of Governmental Industrial Hygienists, Inc., 1987. 


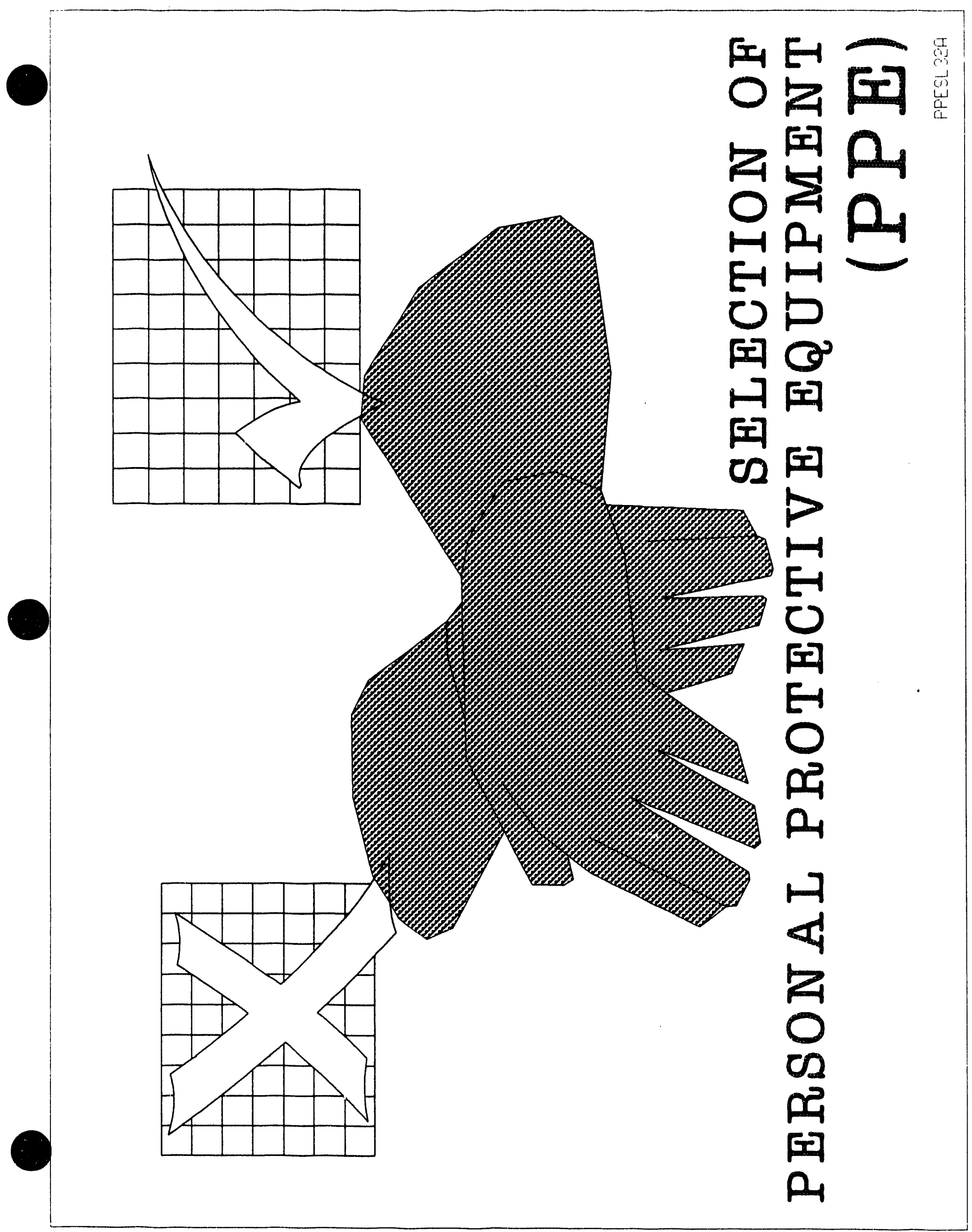




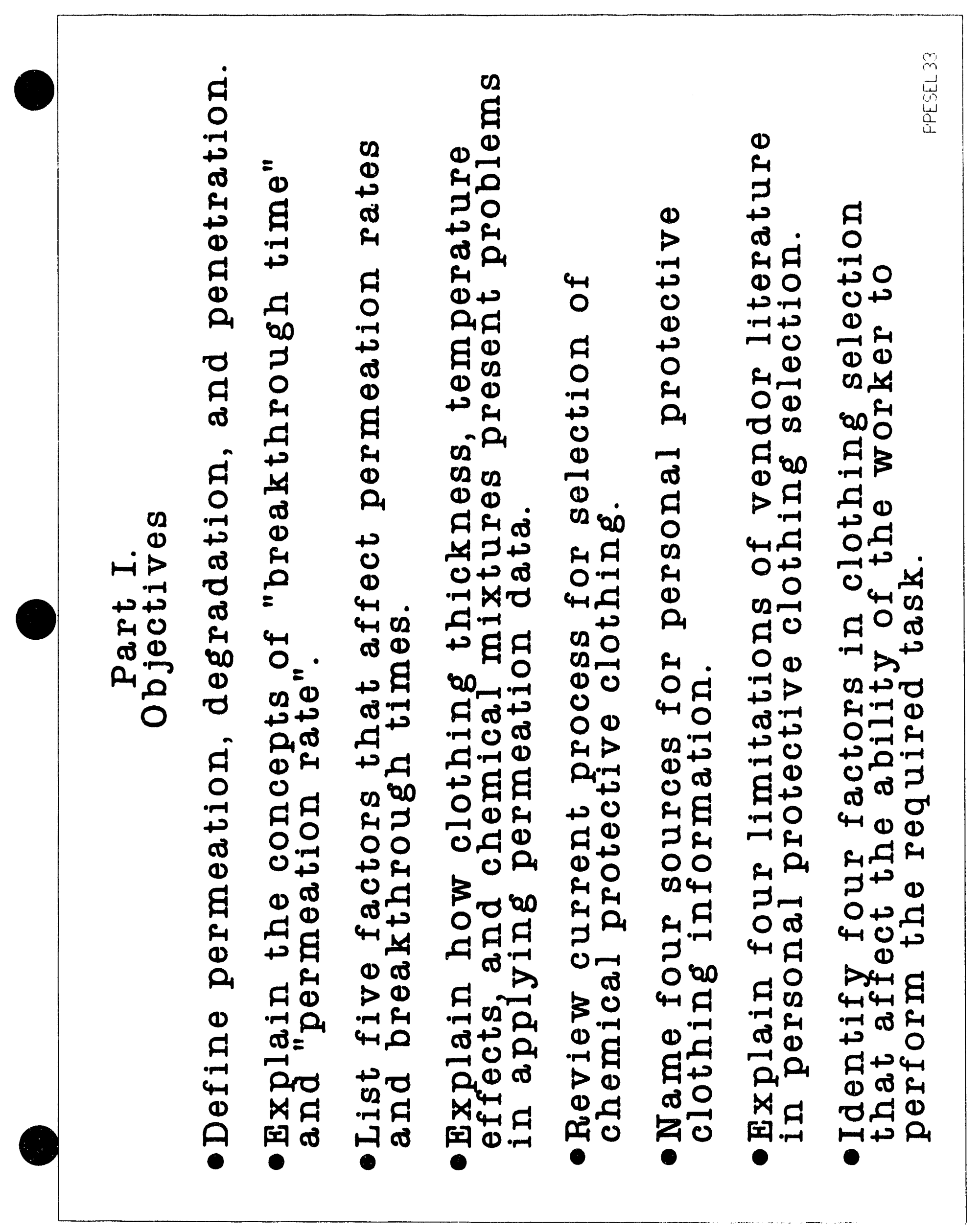




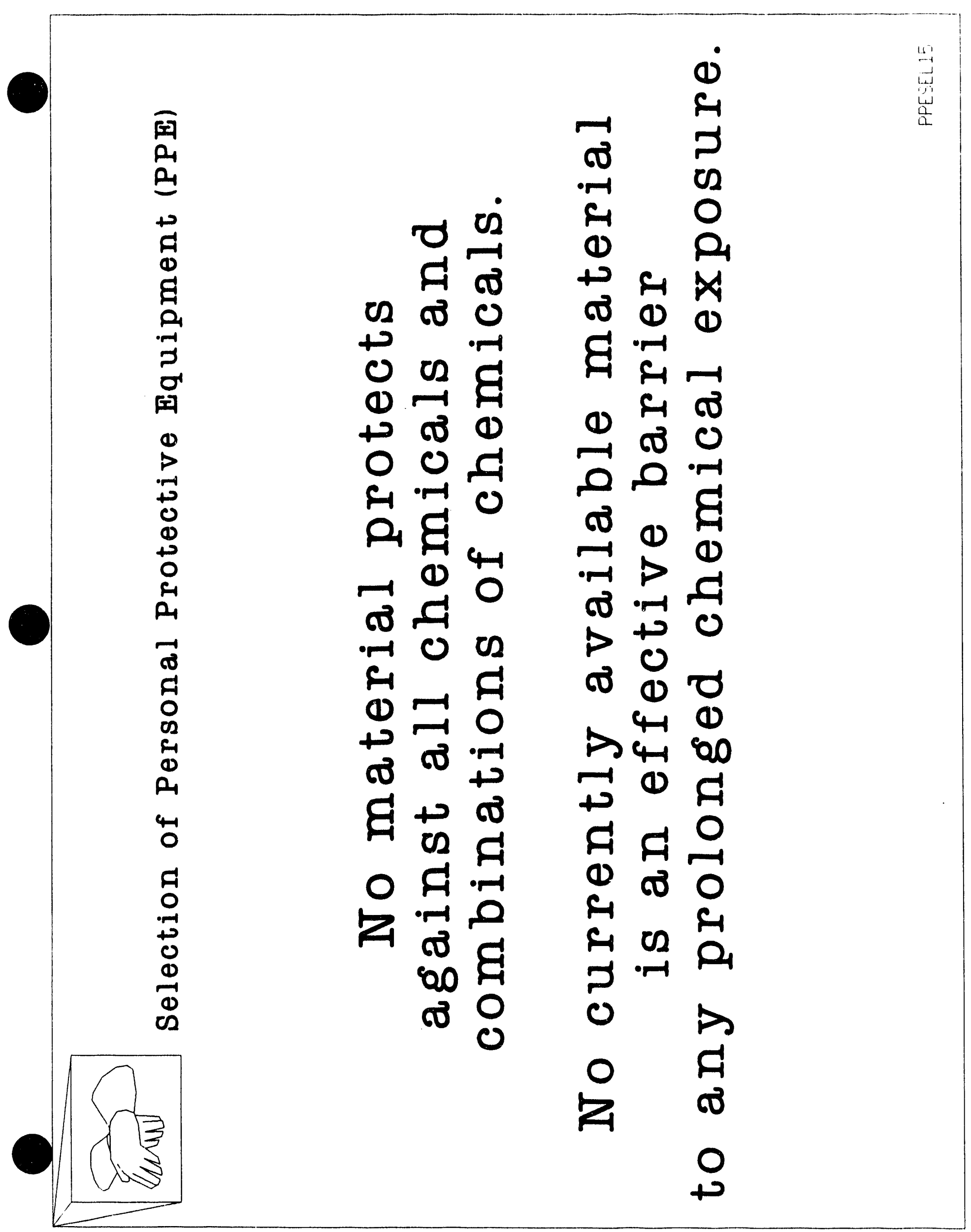




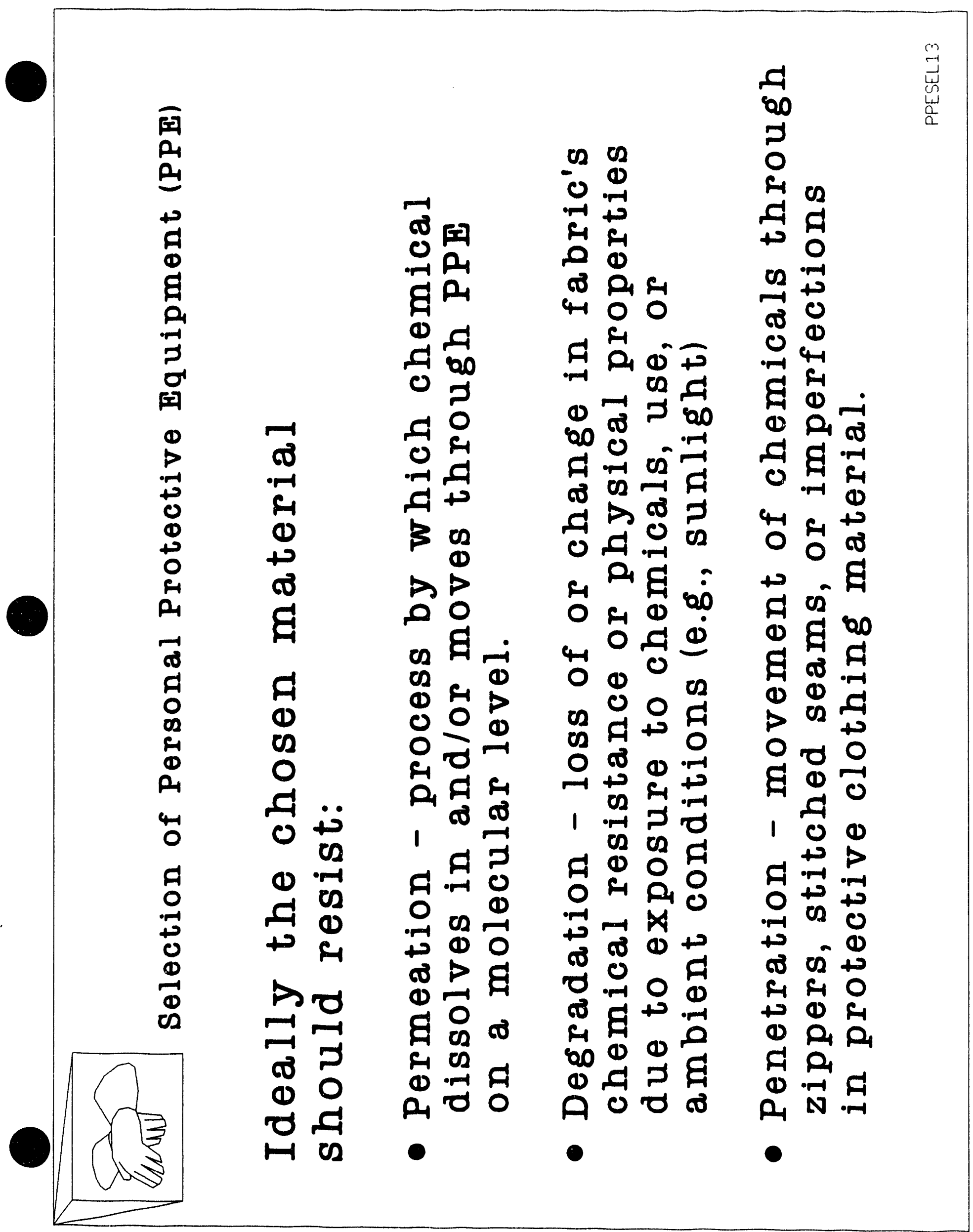




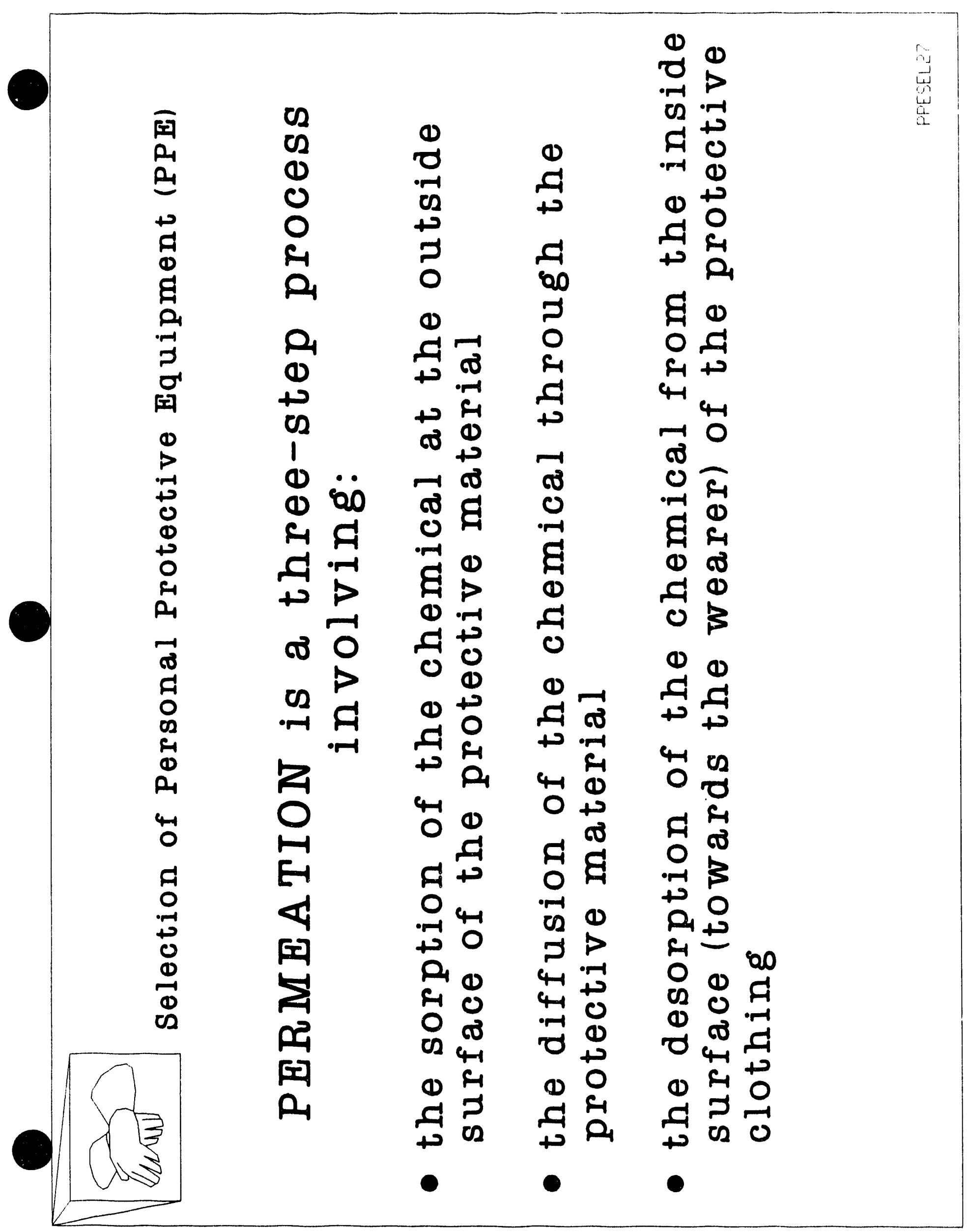




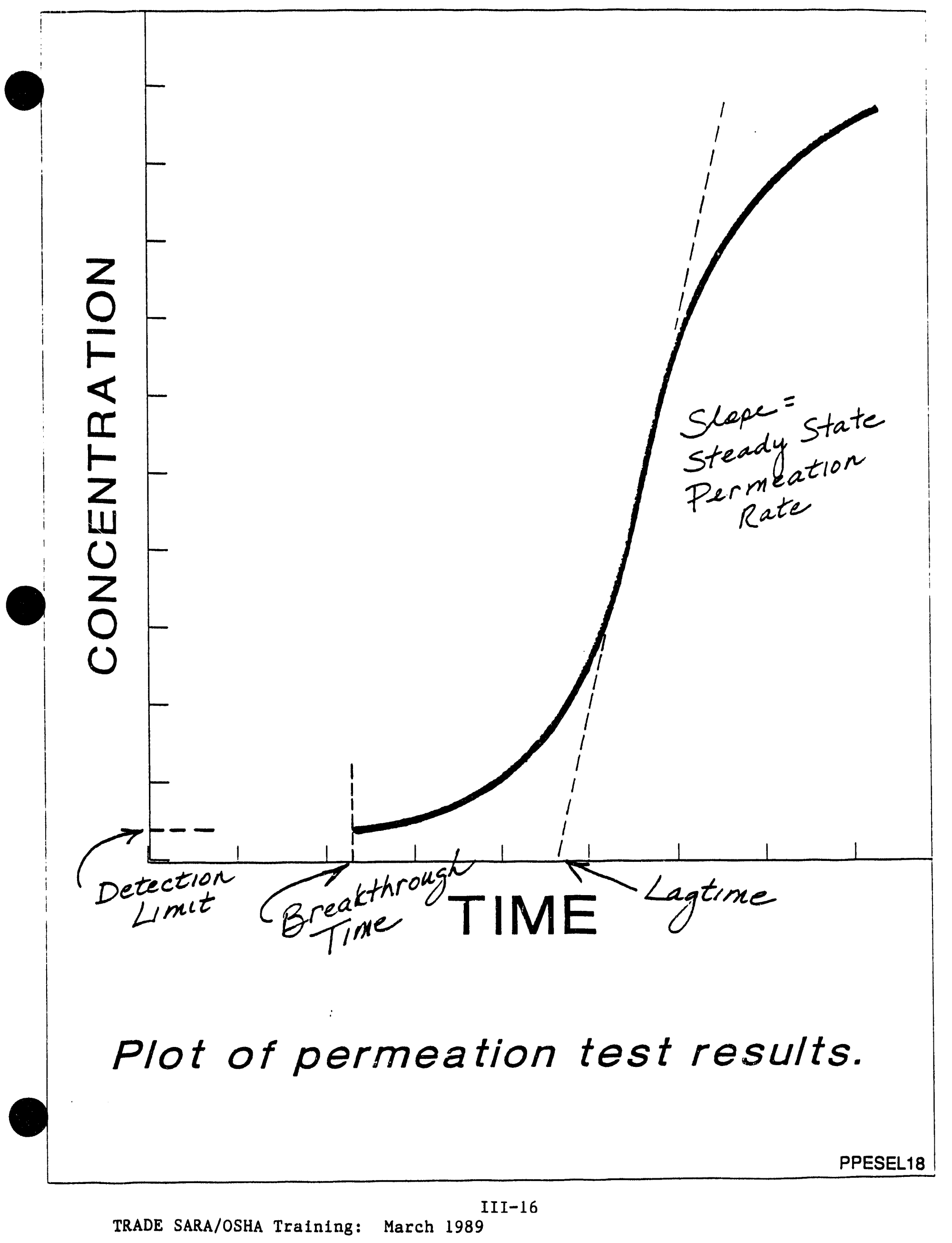




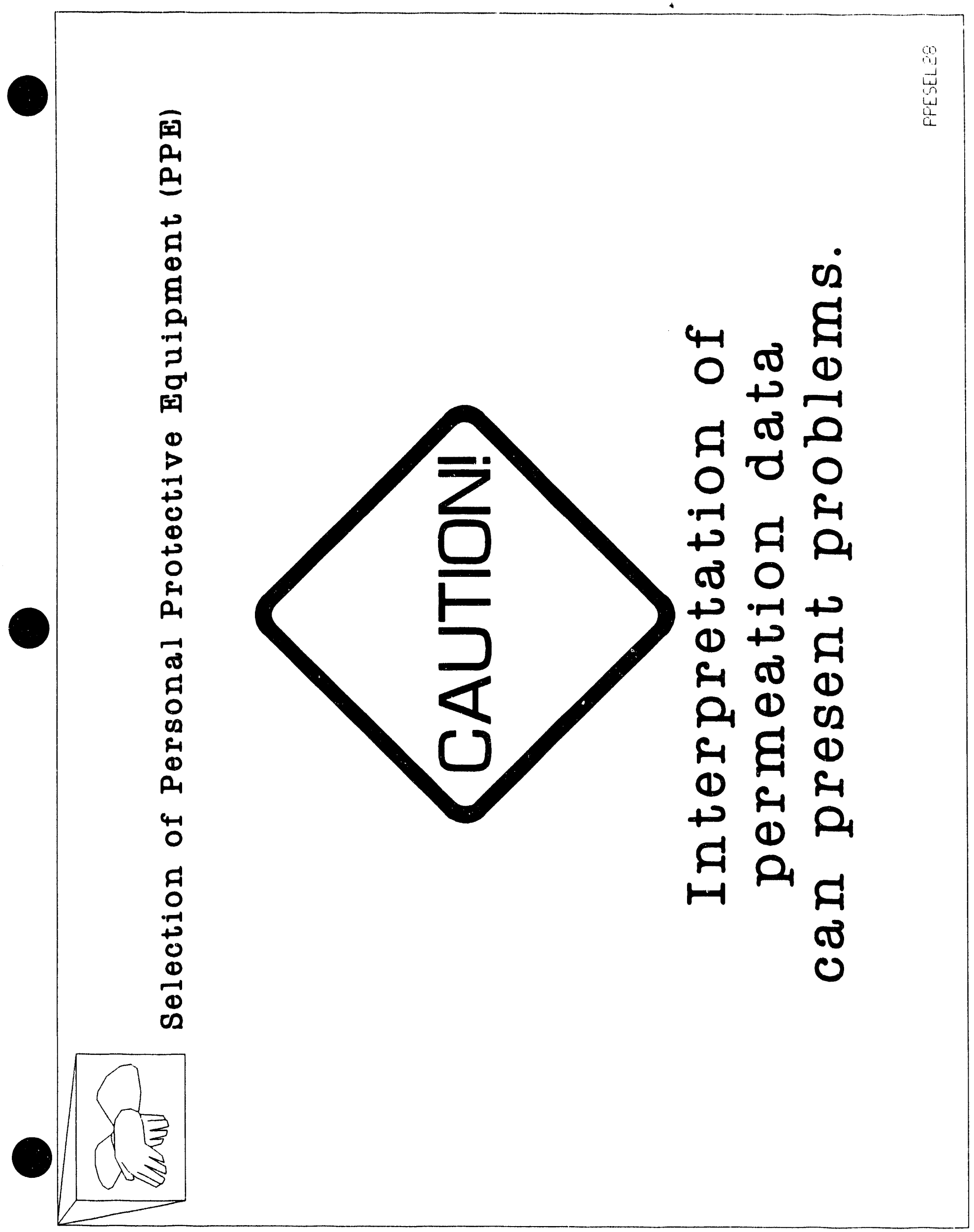




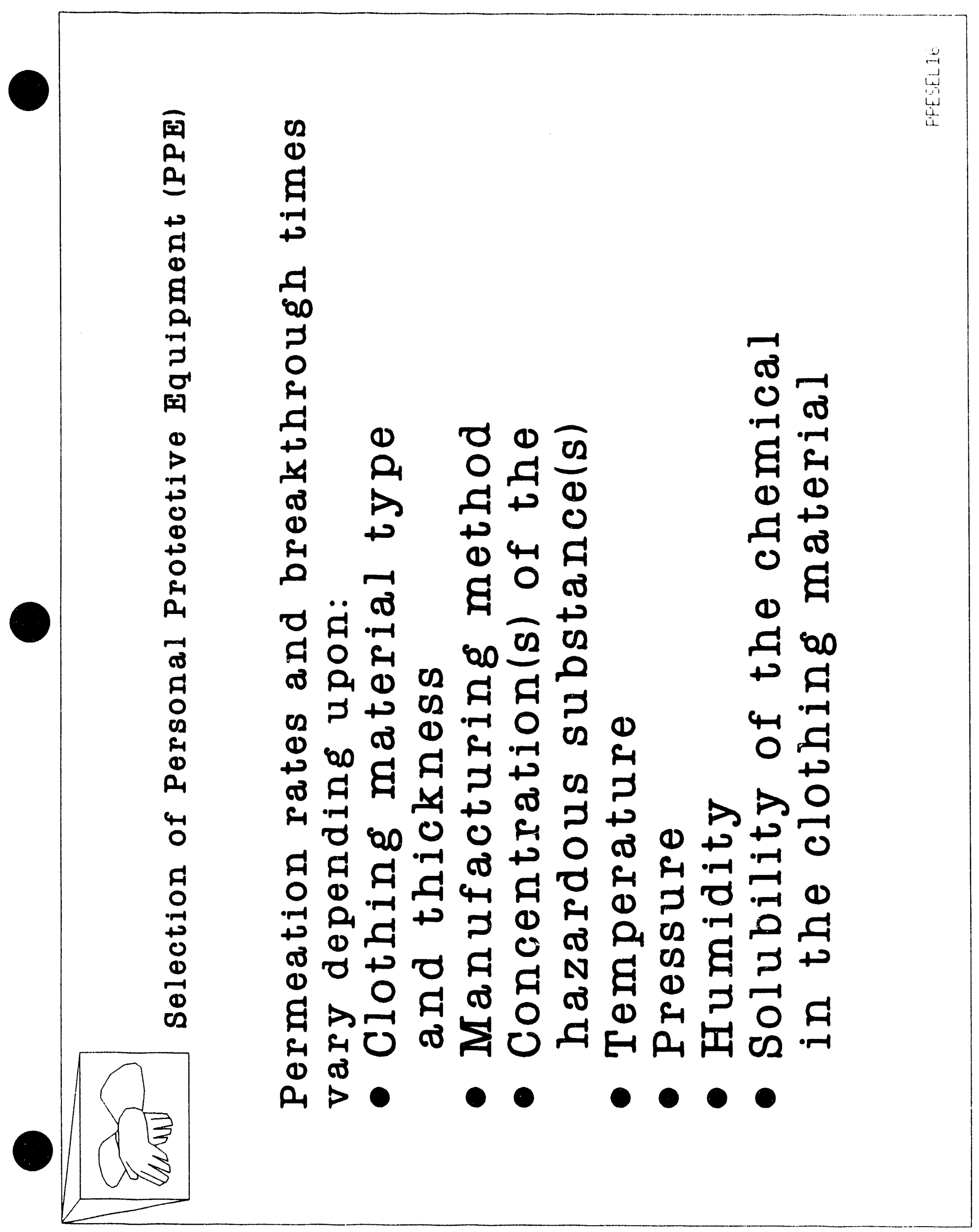




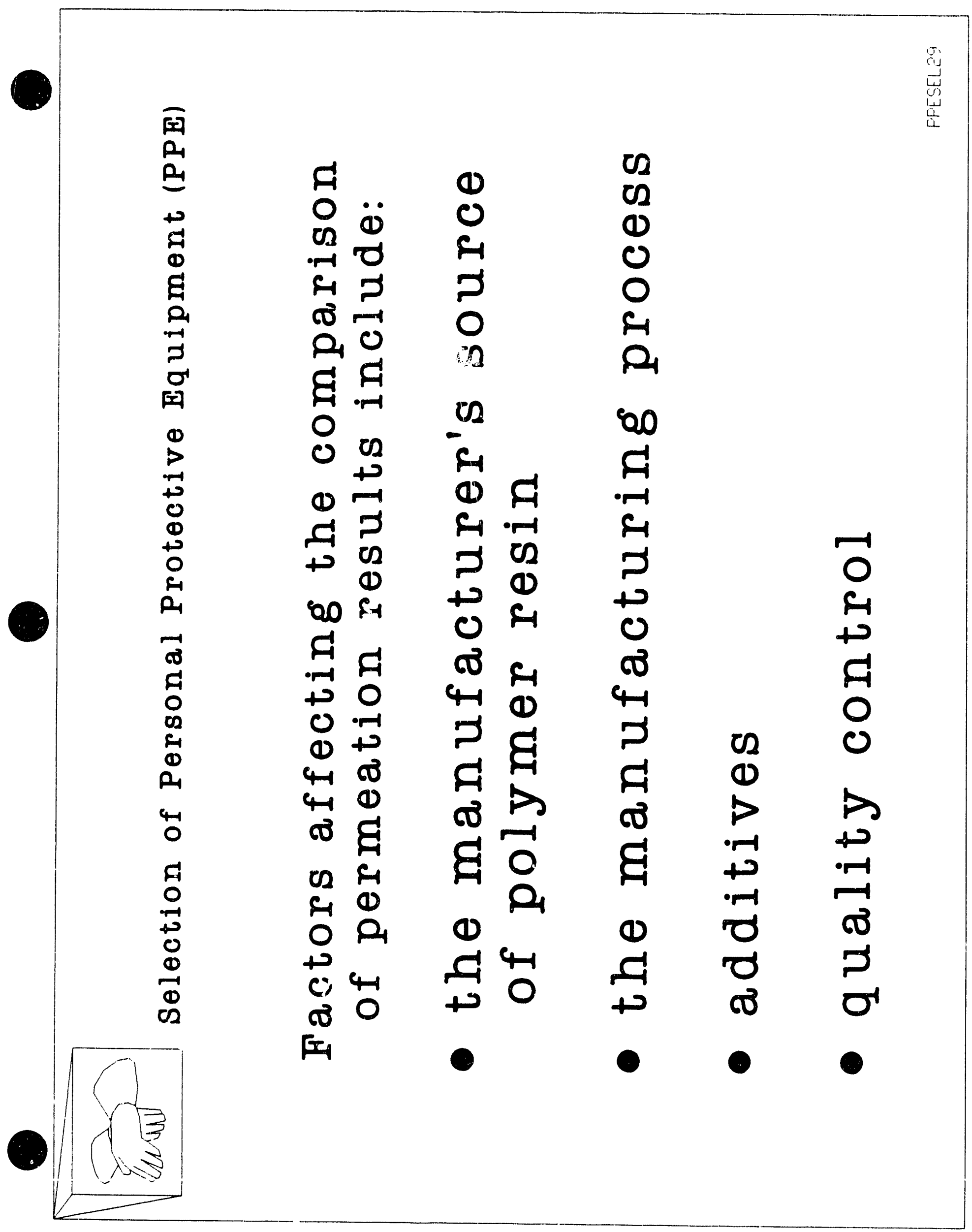




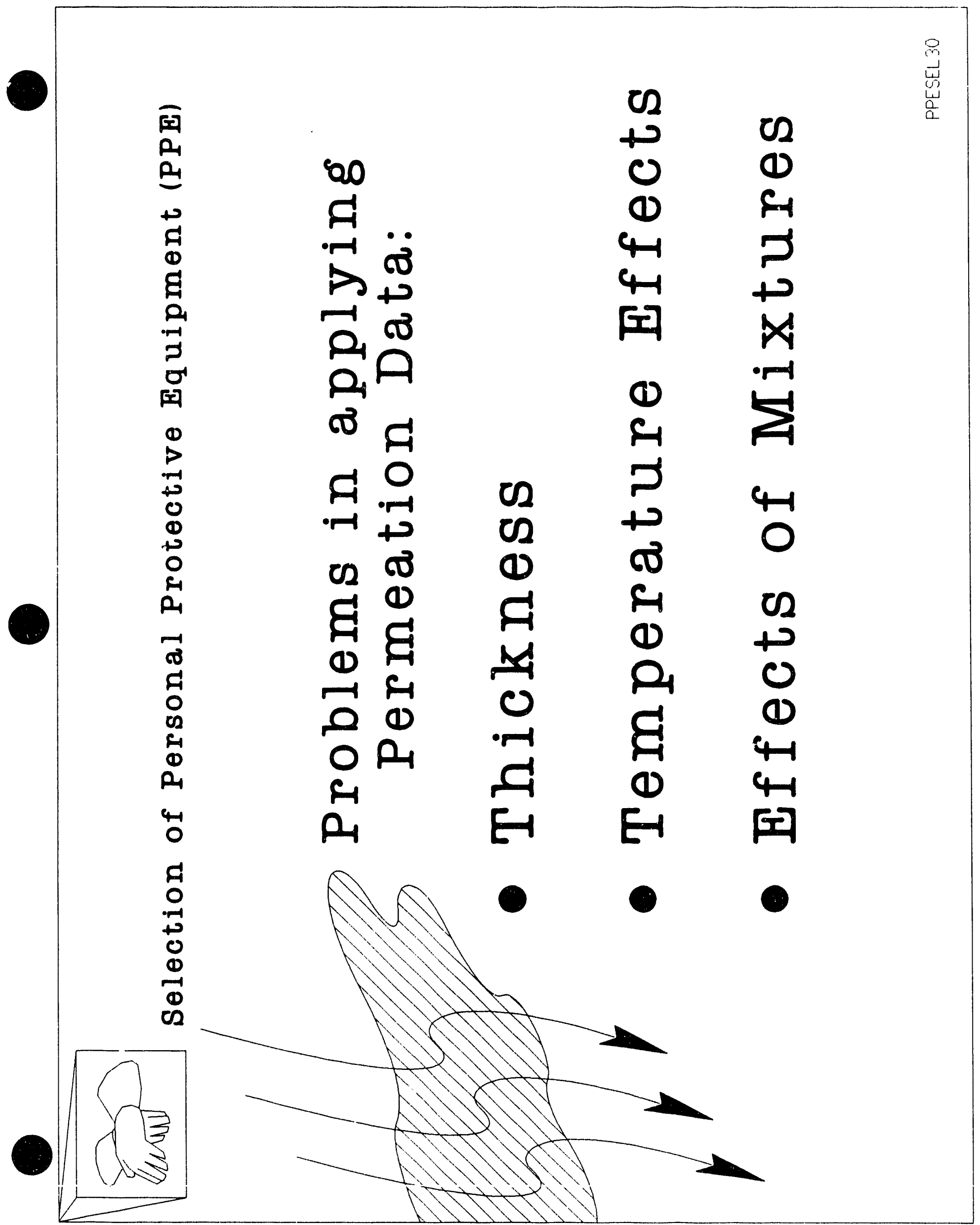




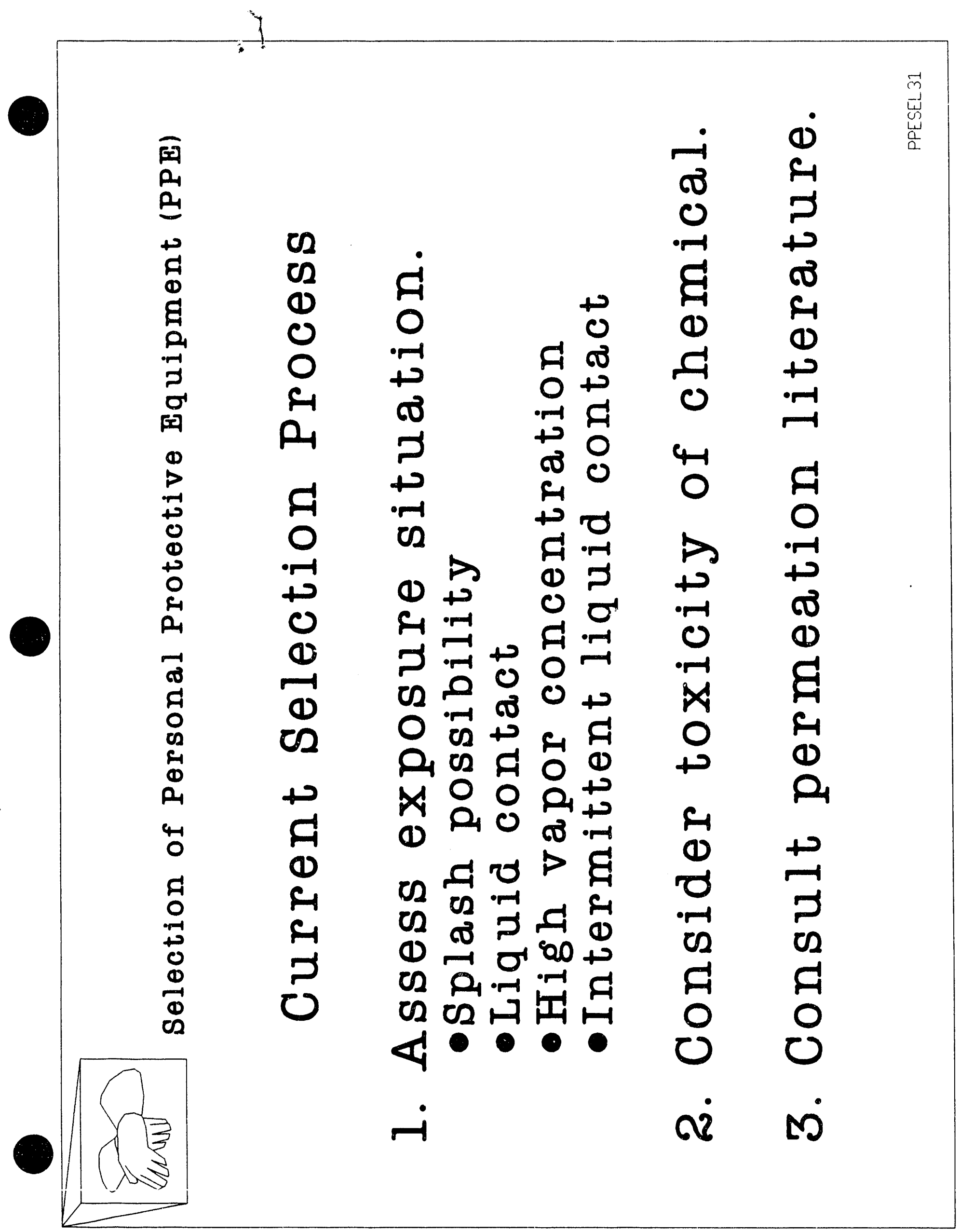




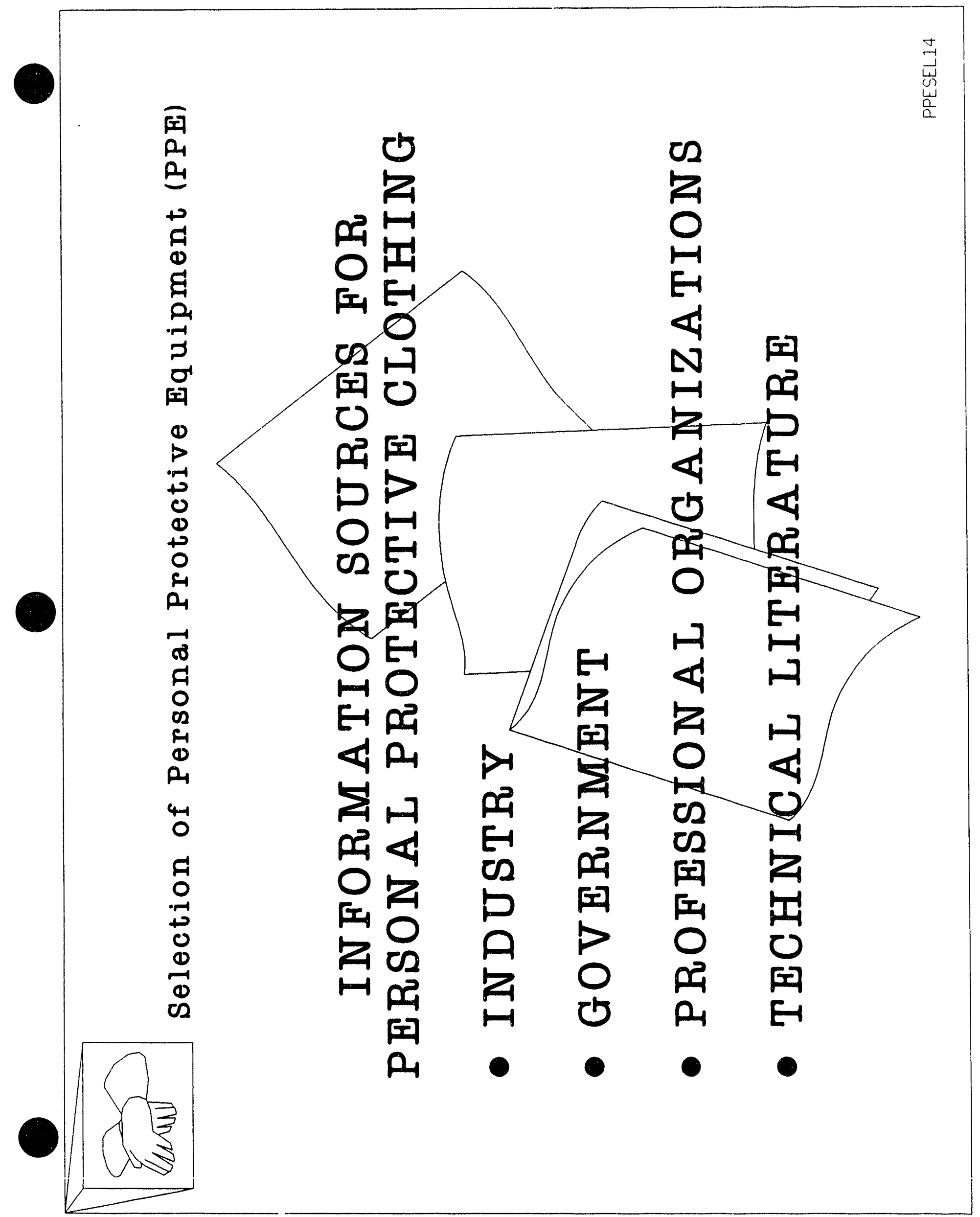




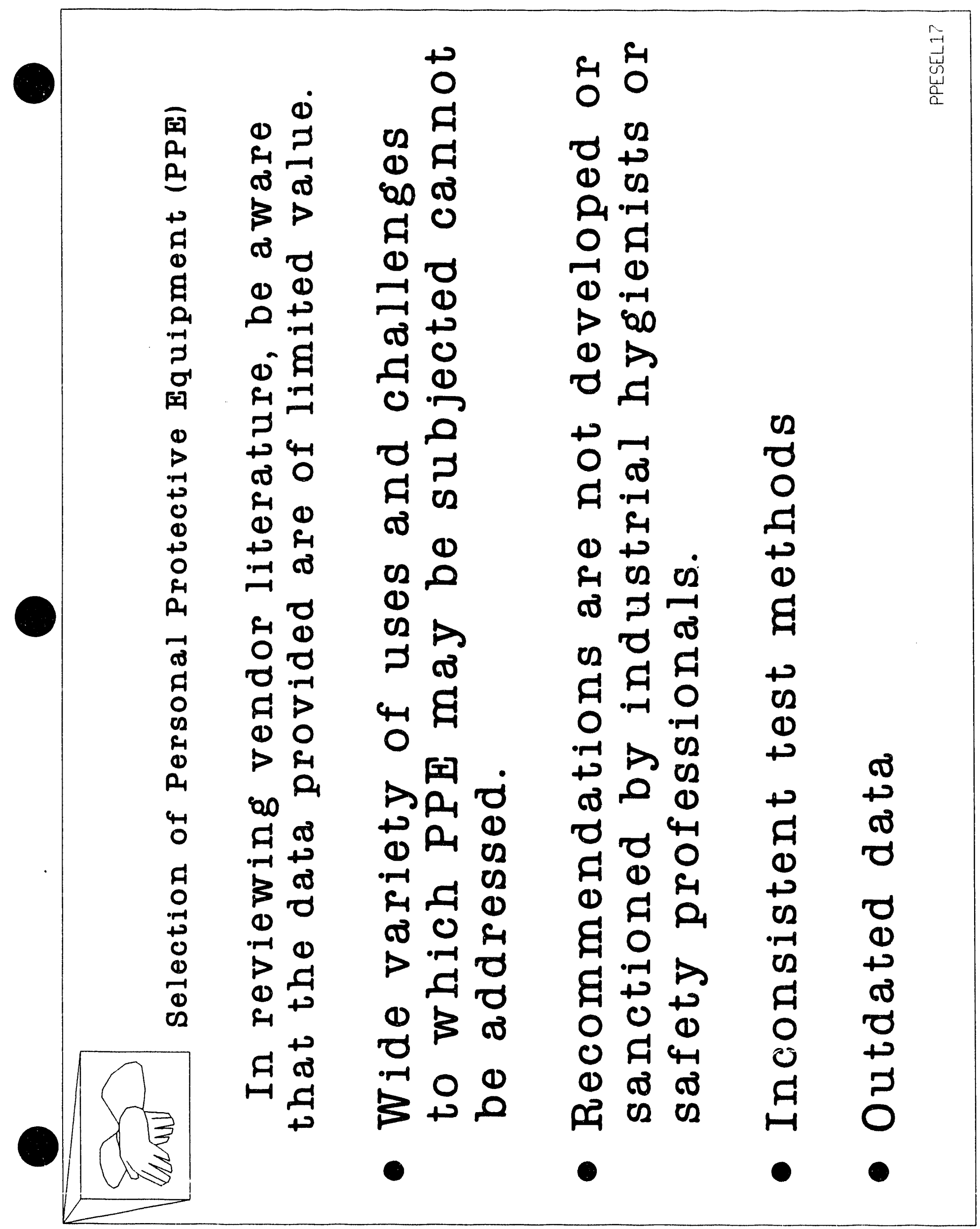




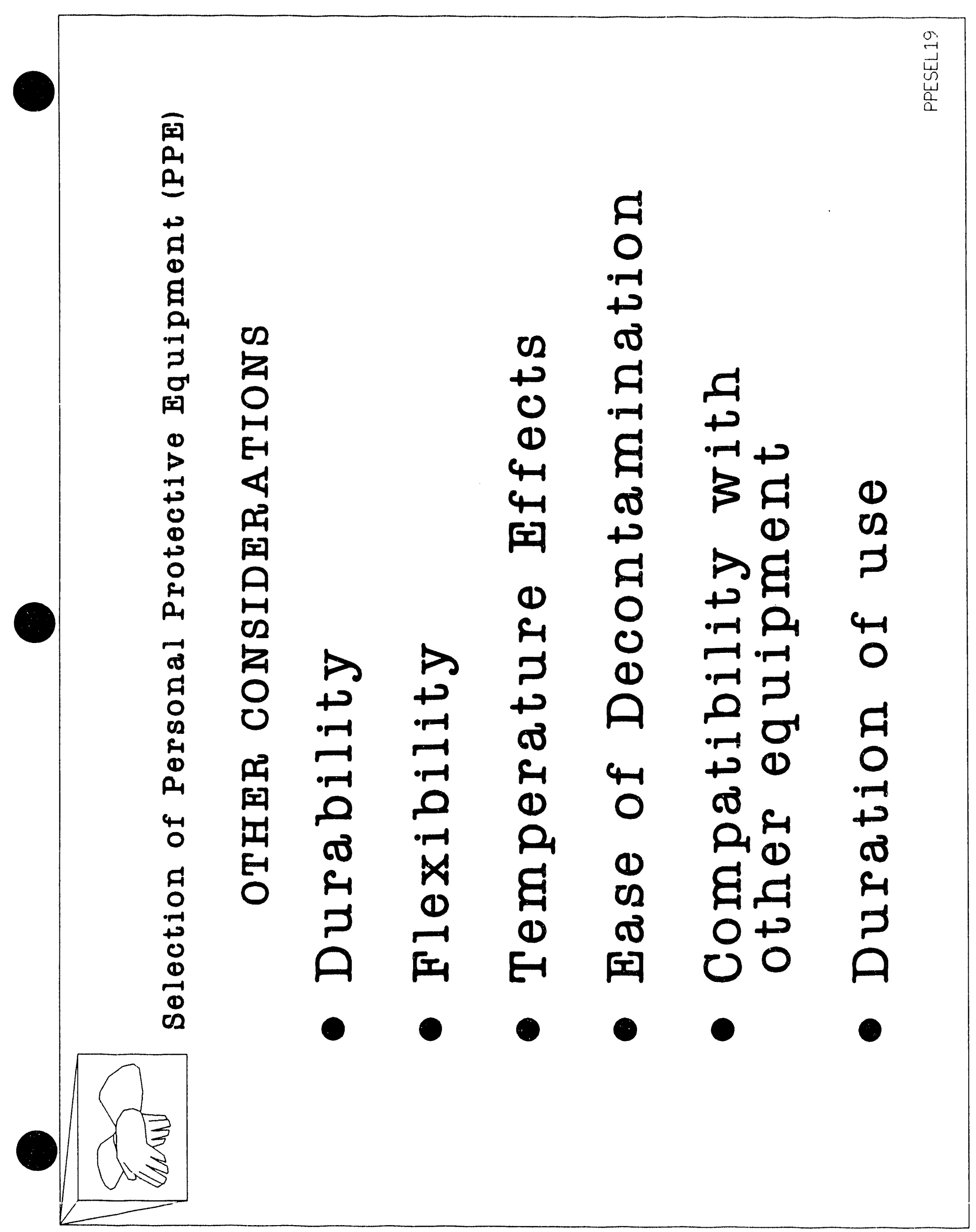




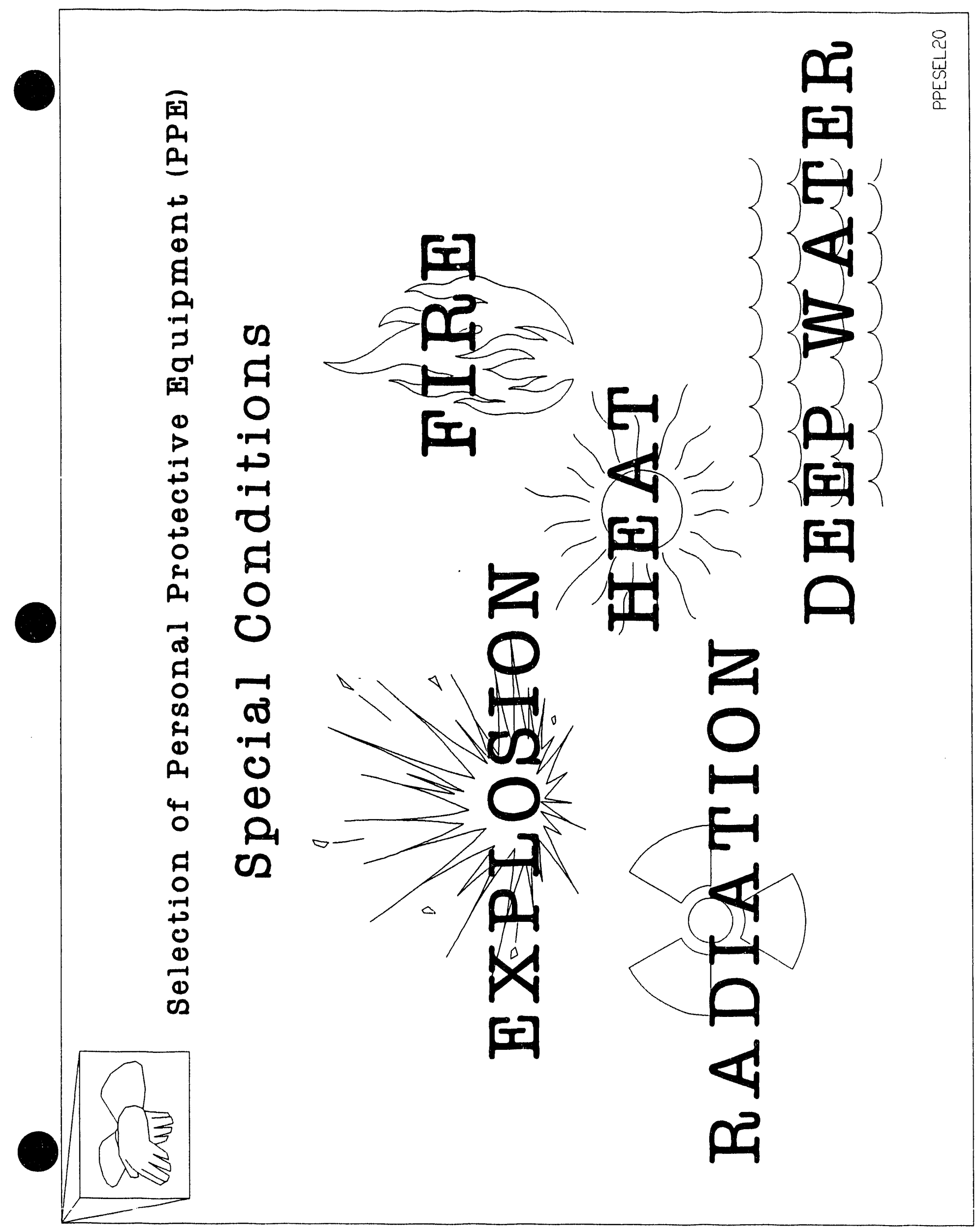




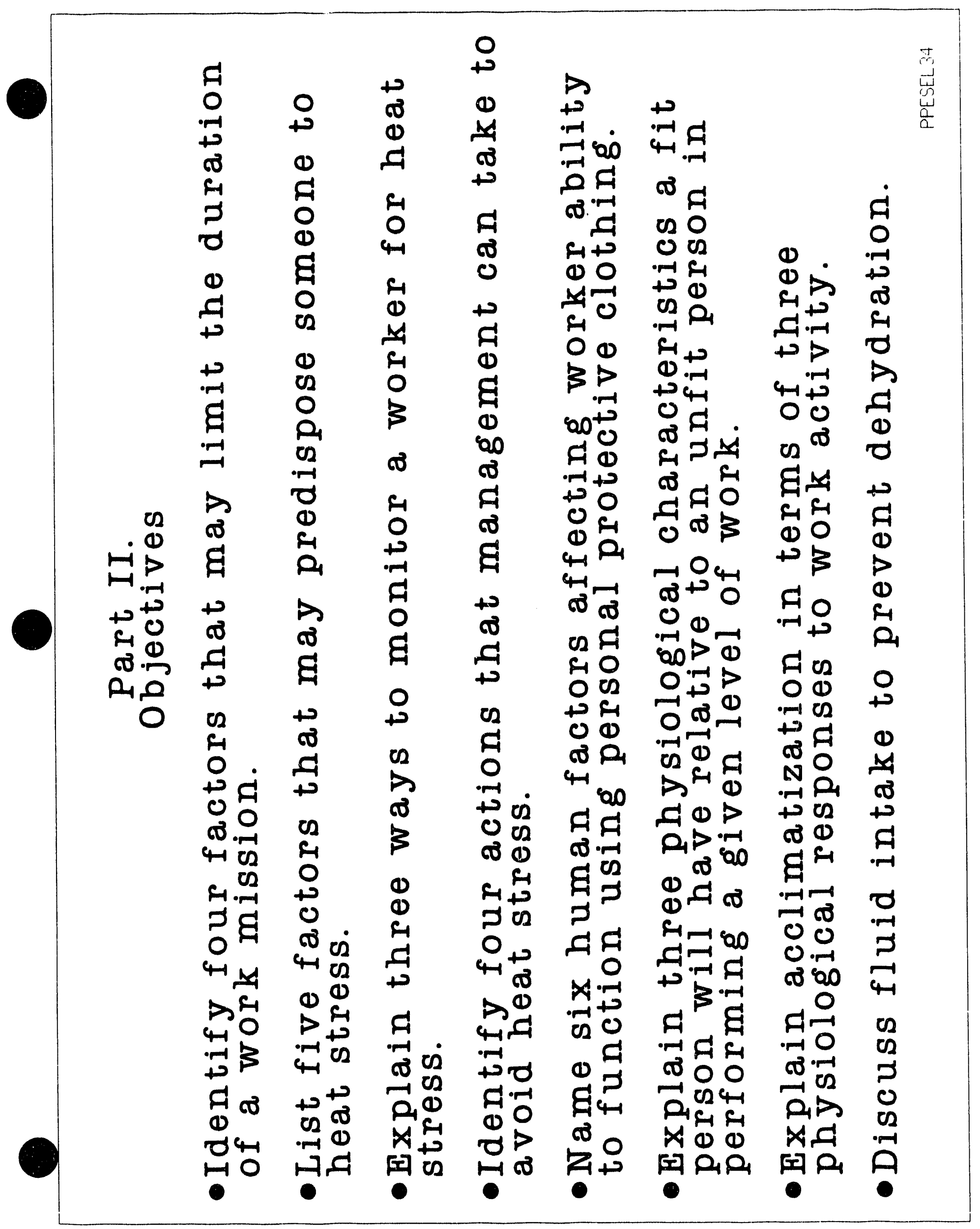




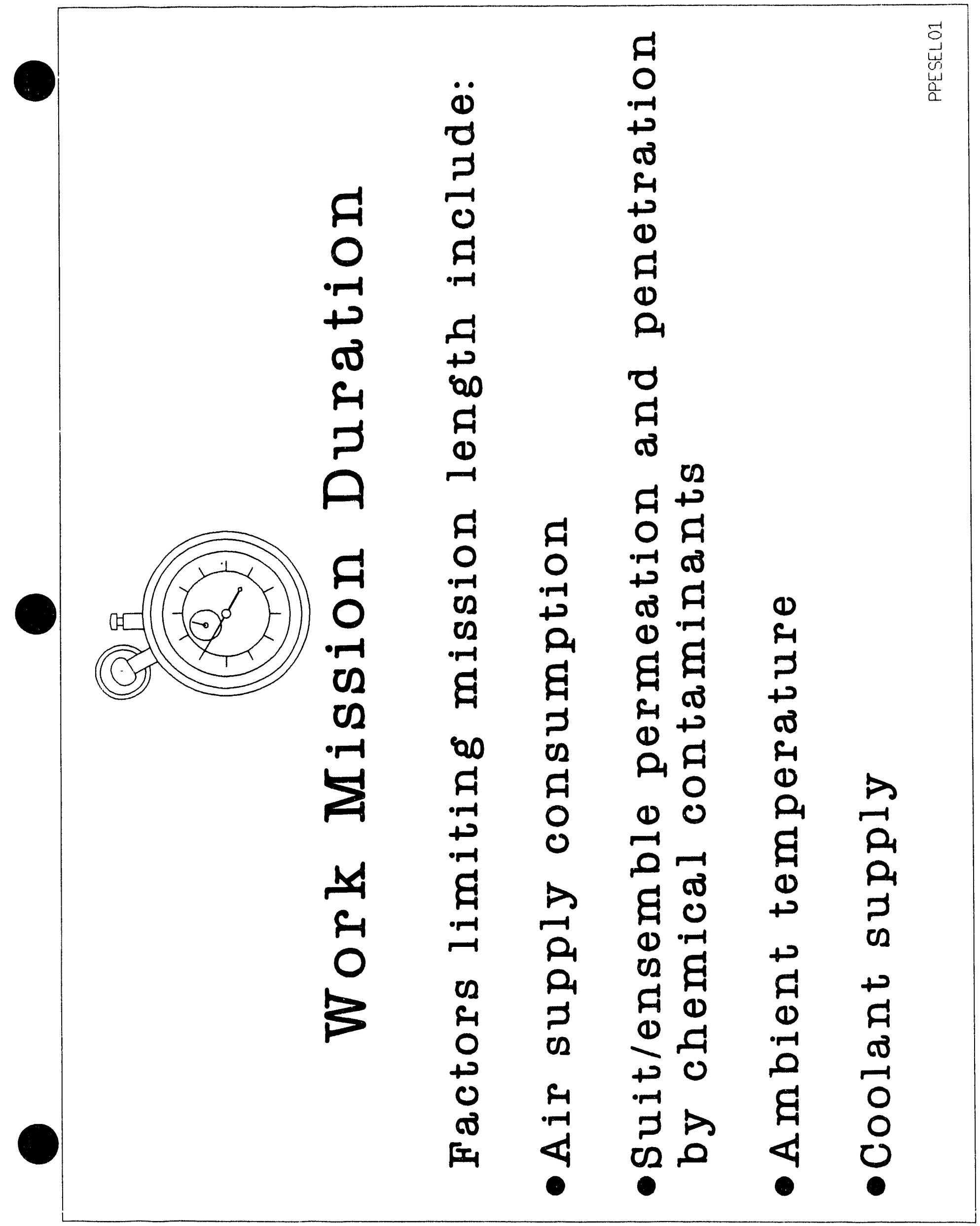




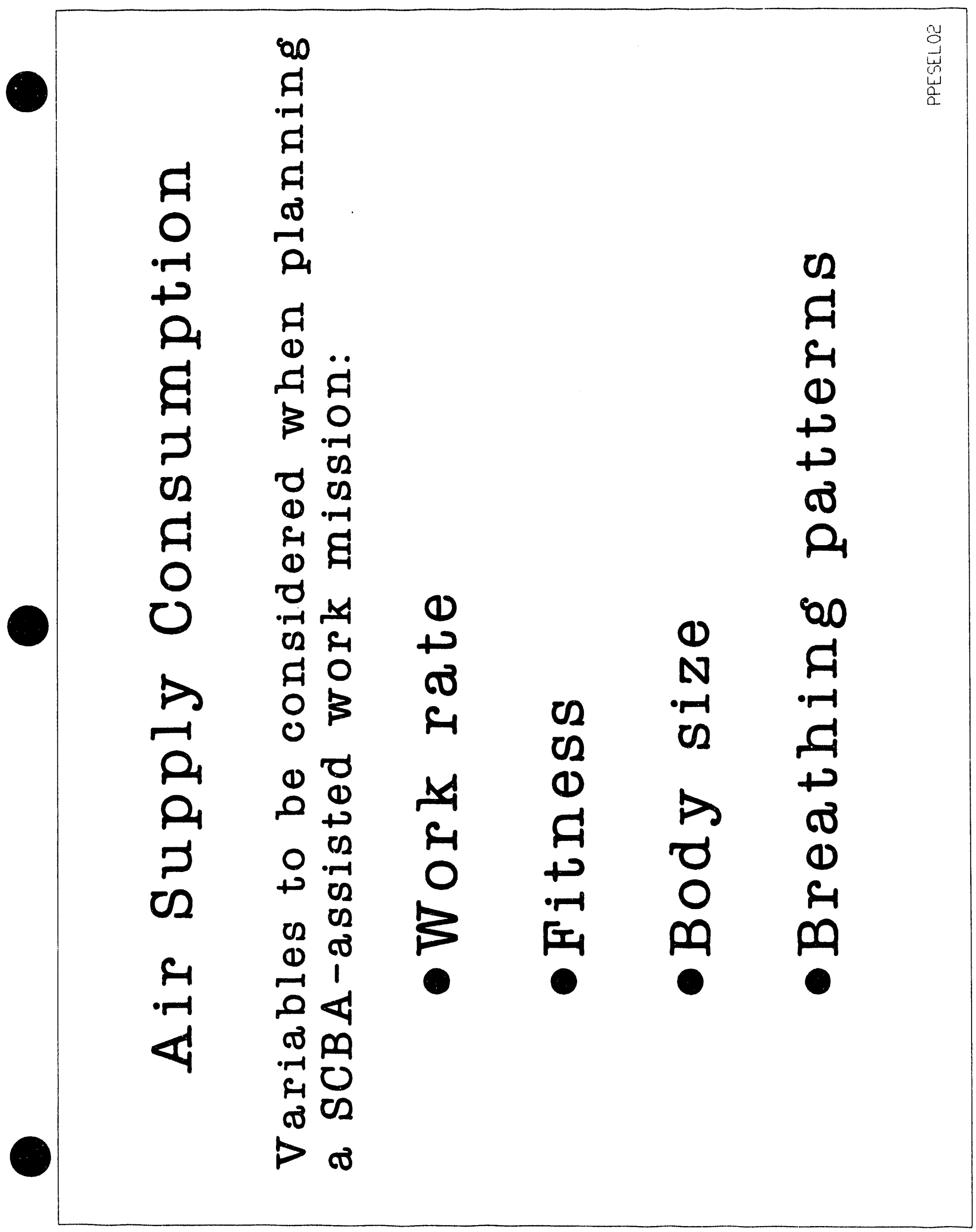




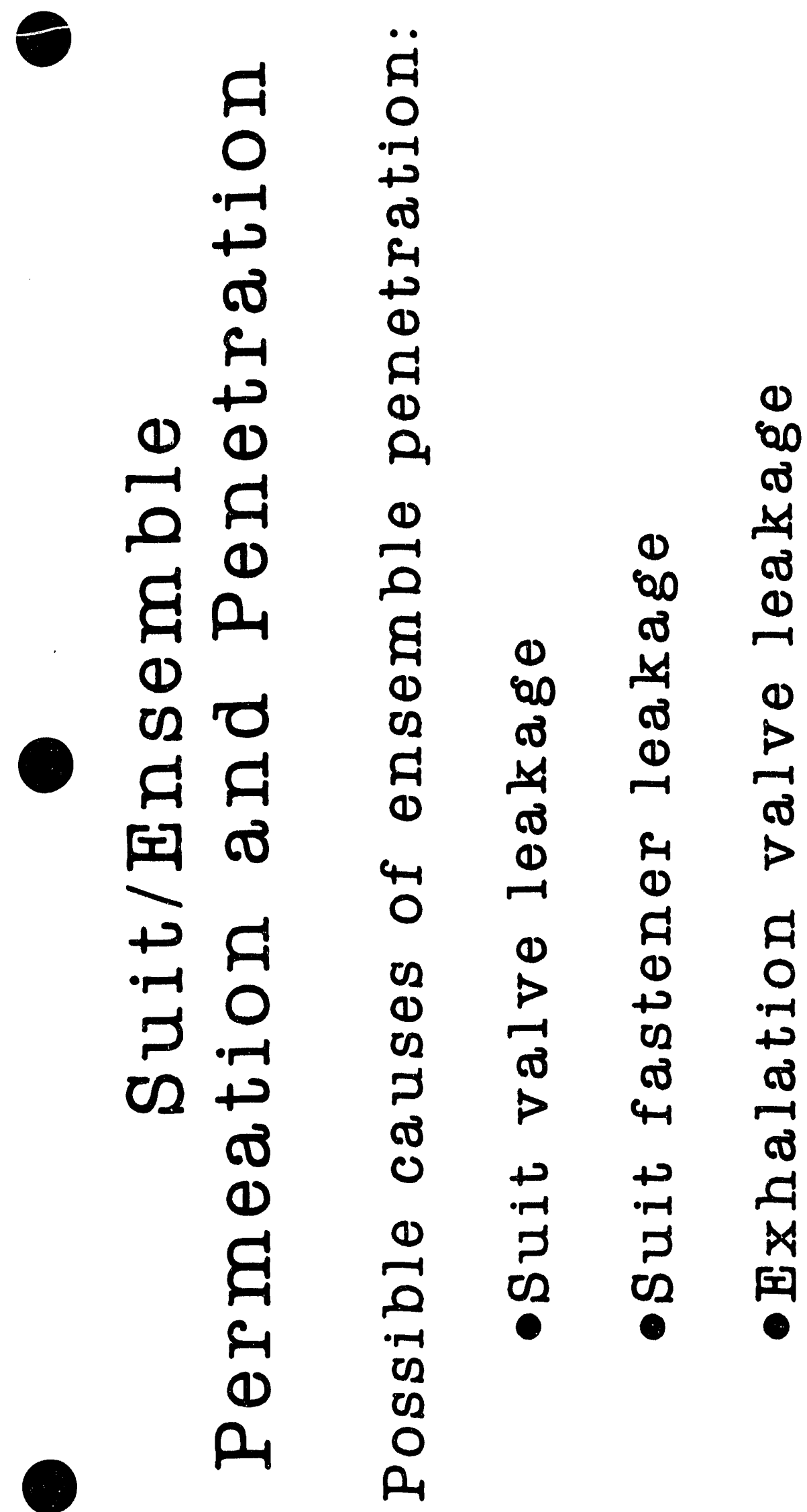

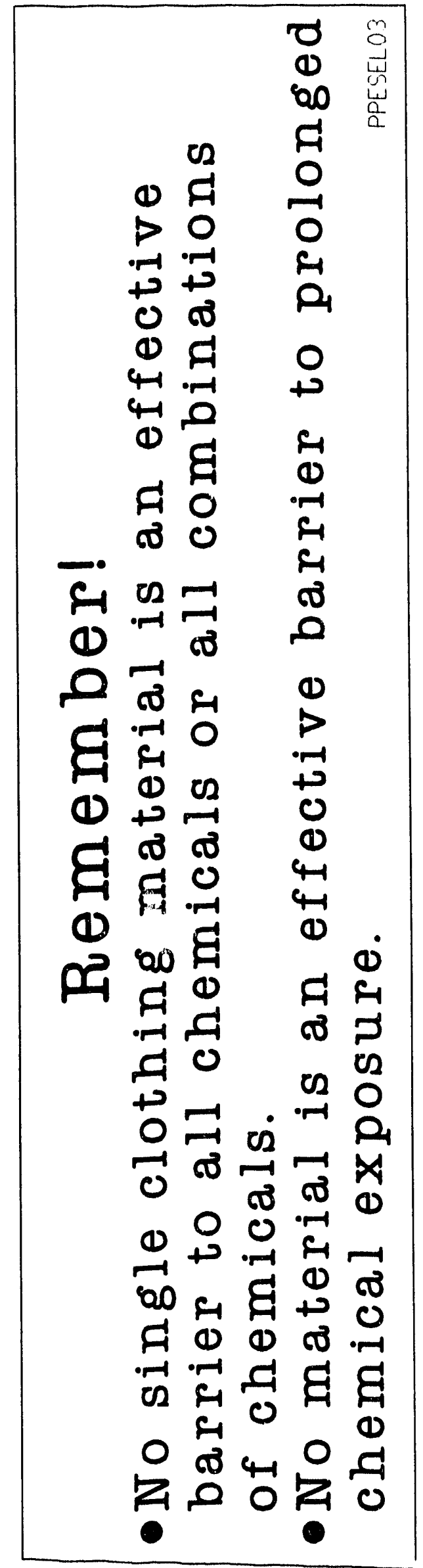




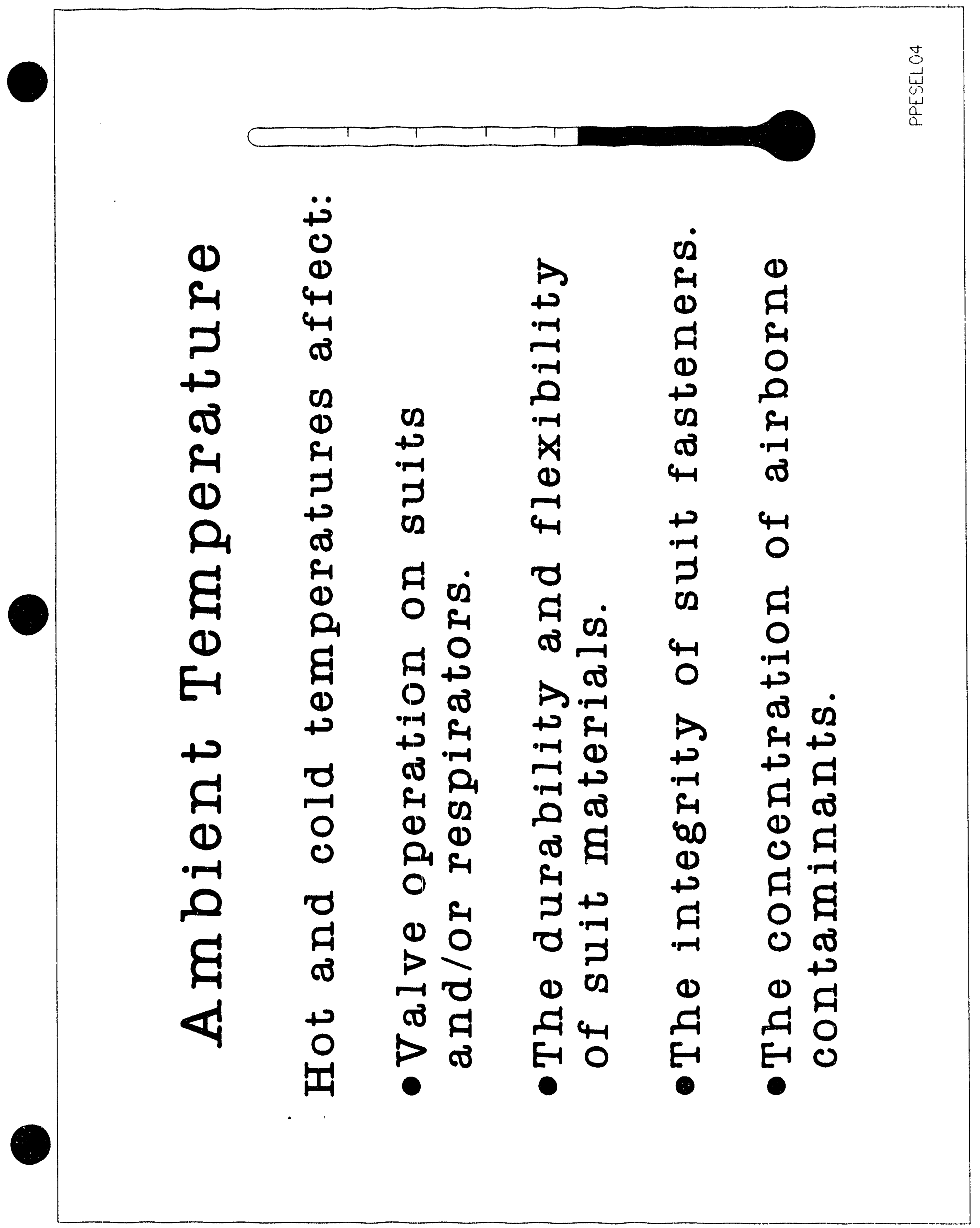




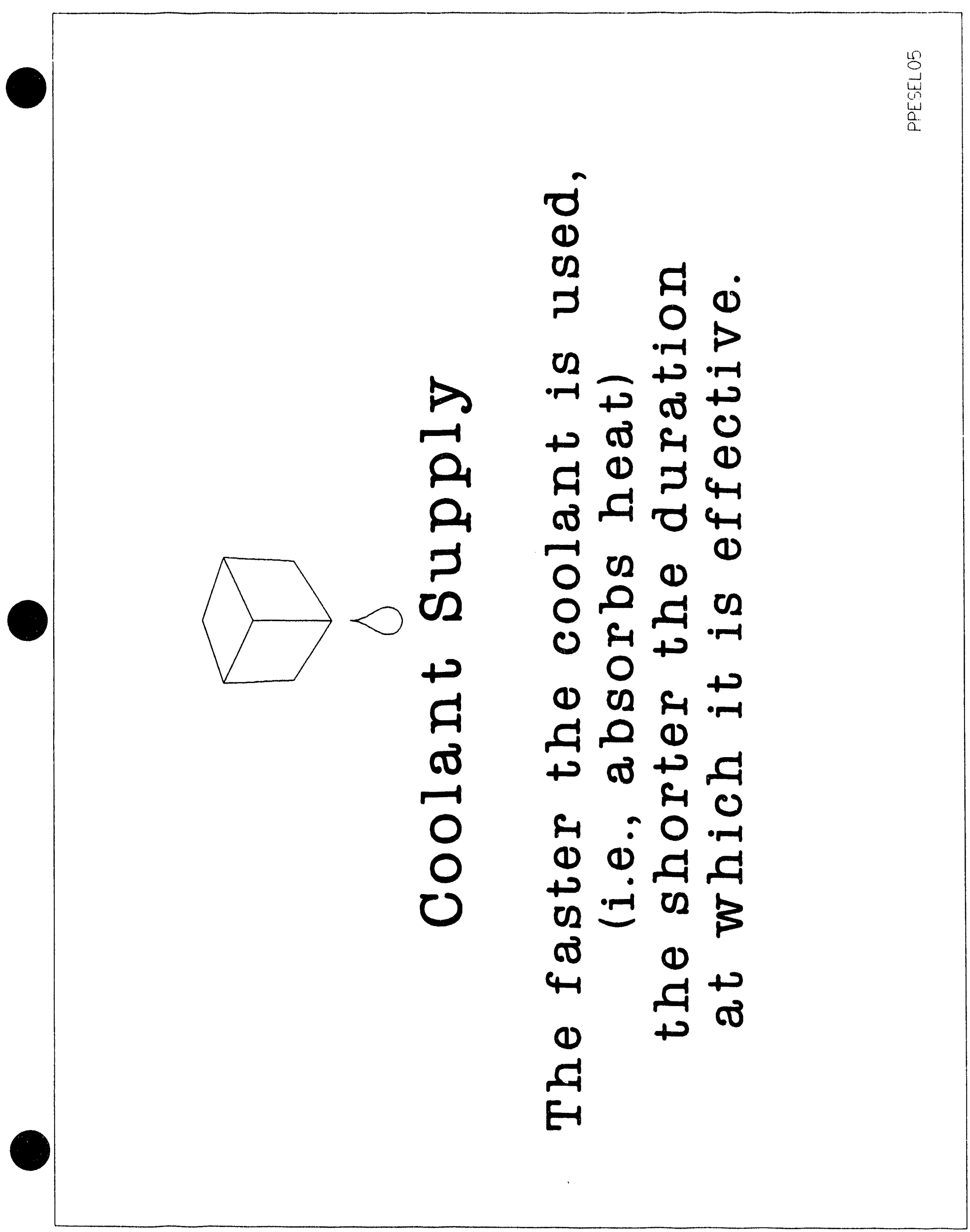




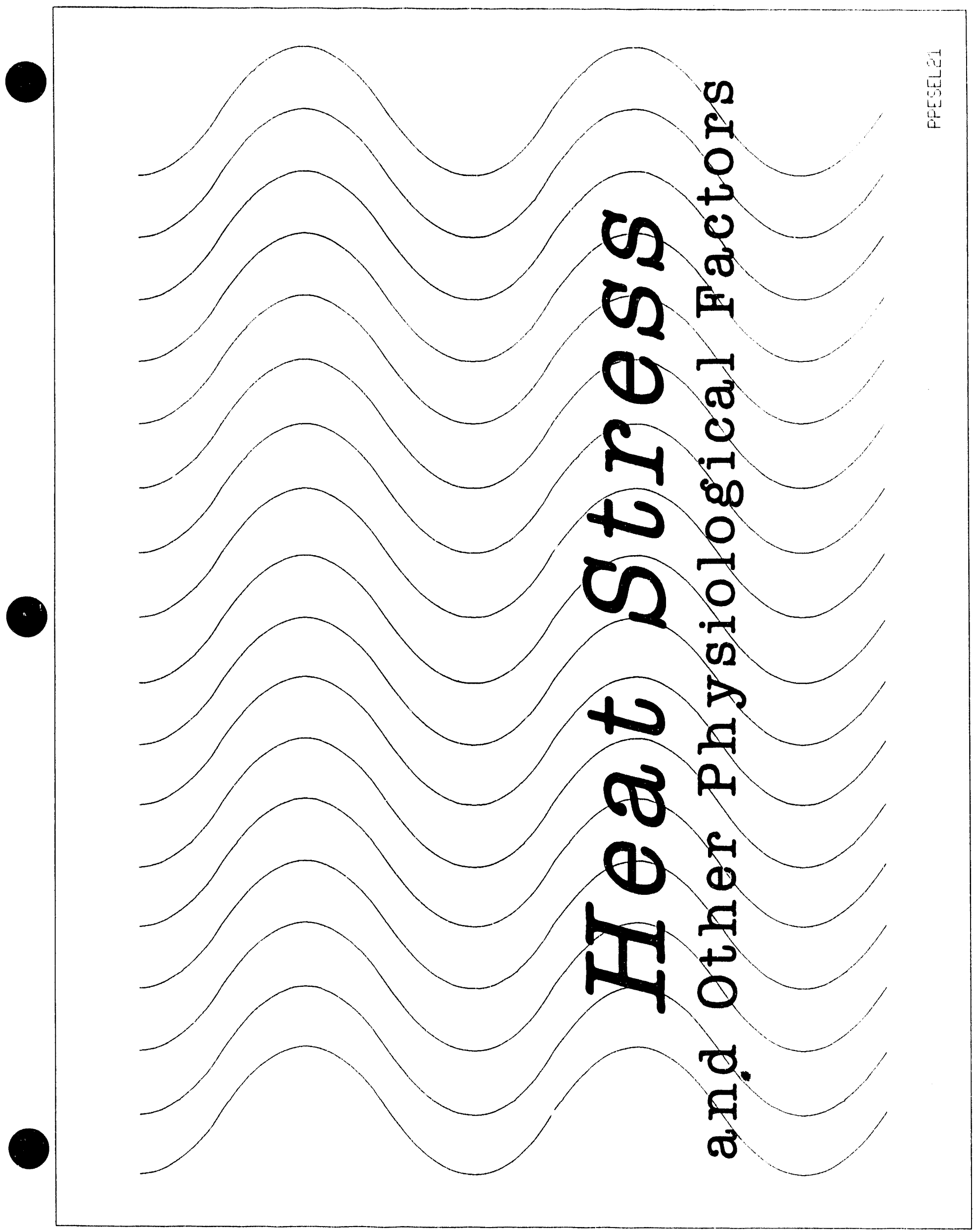




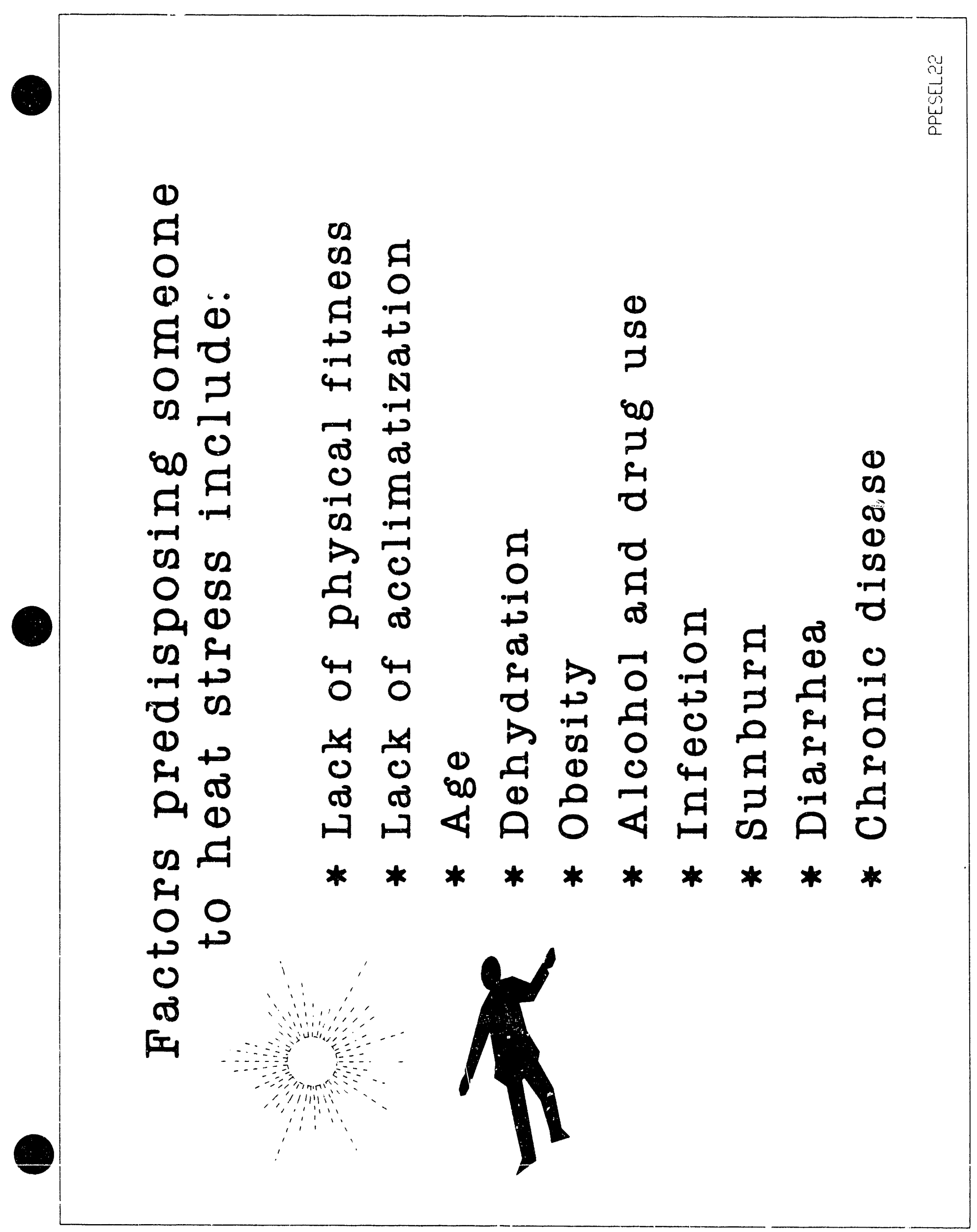




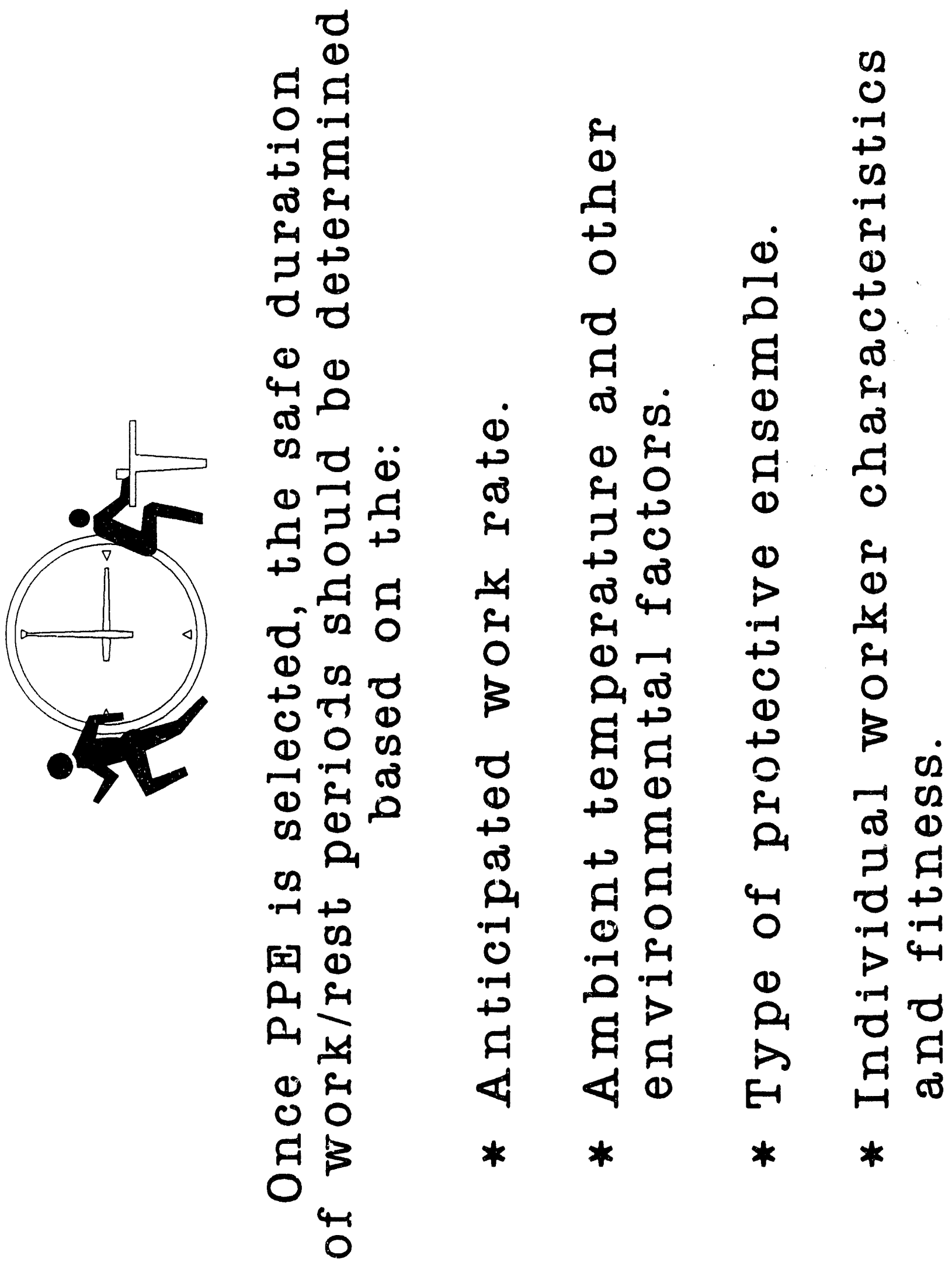




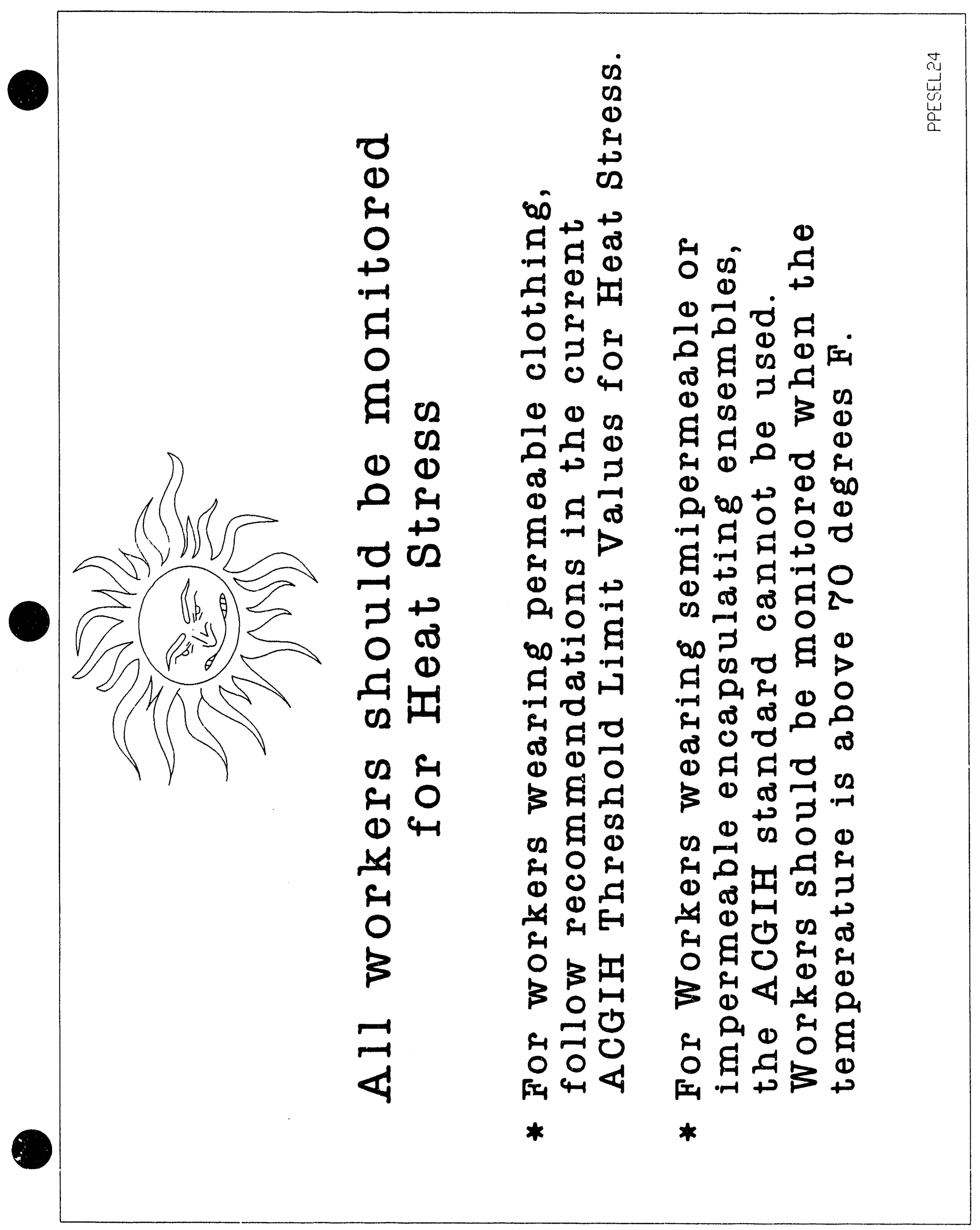




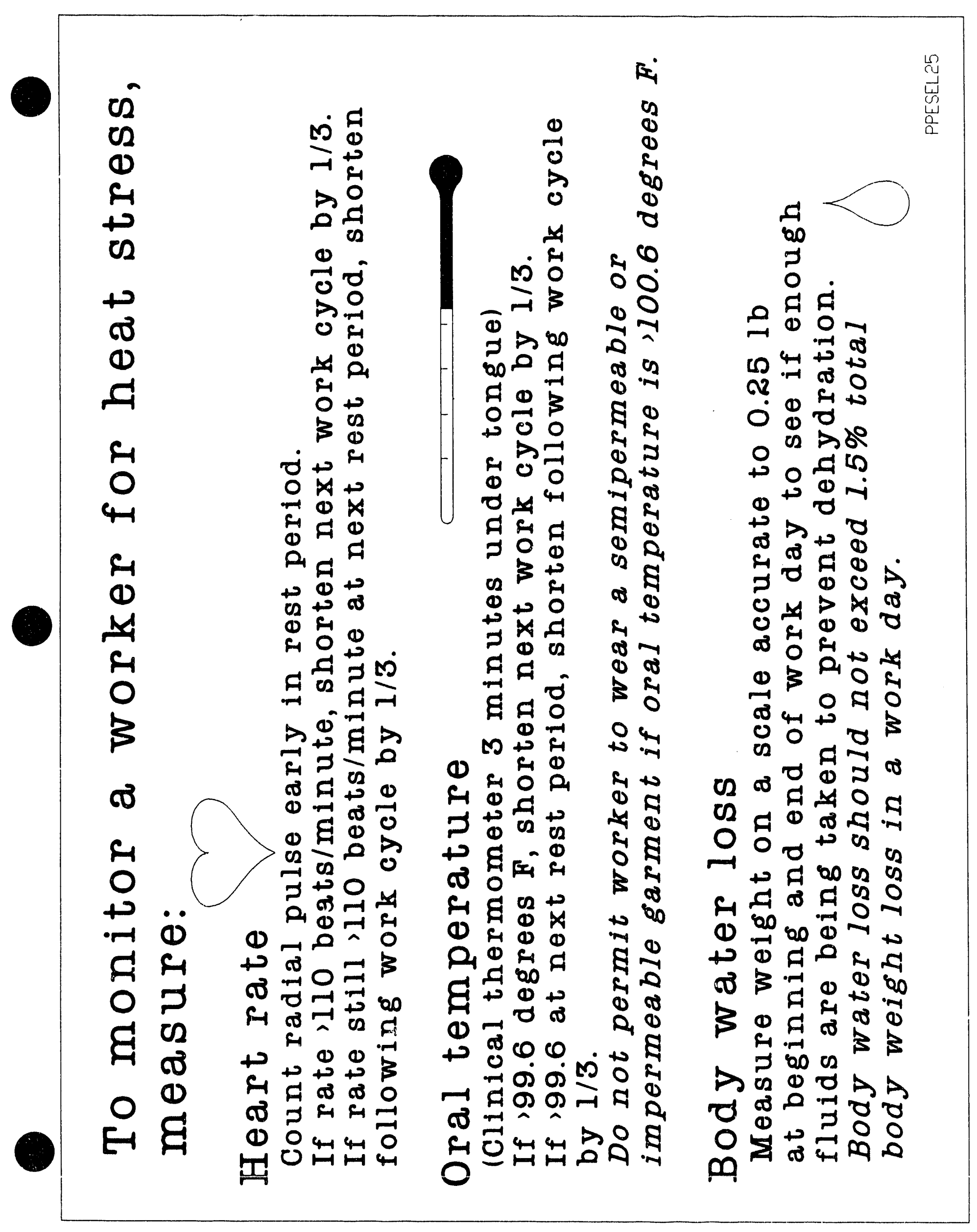




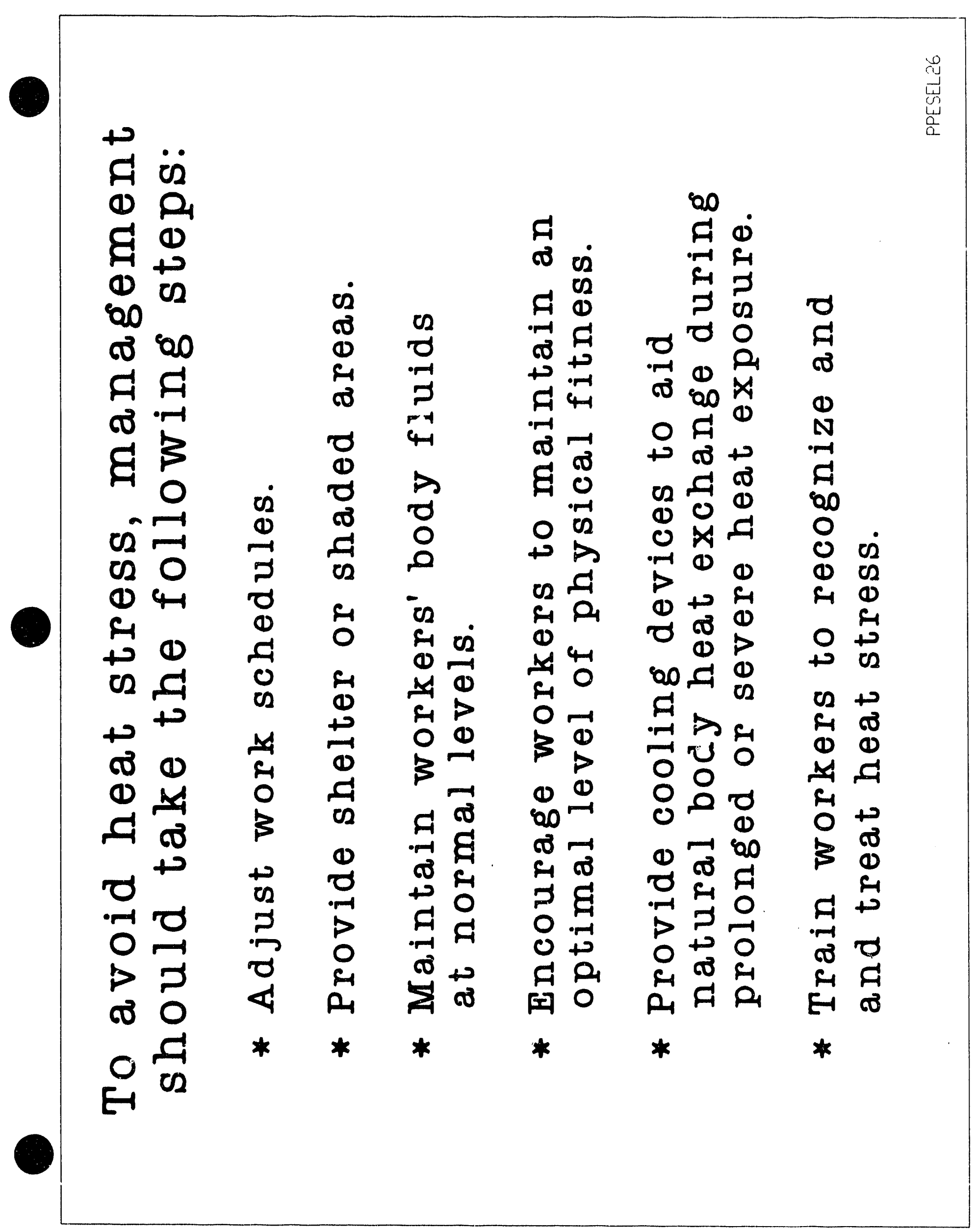




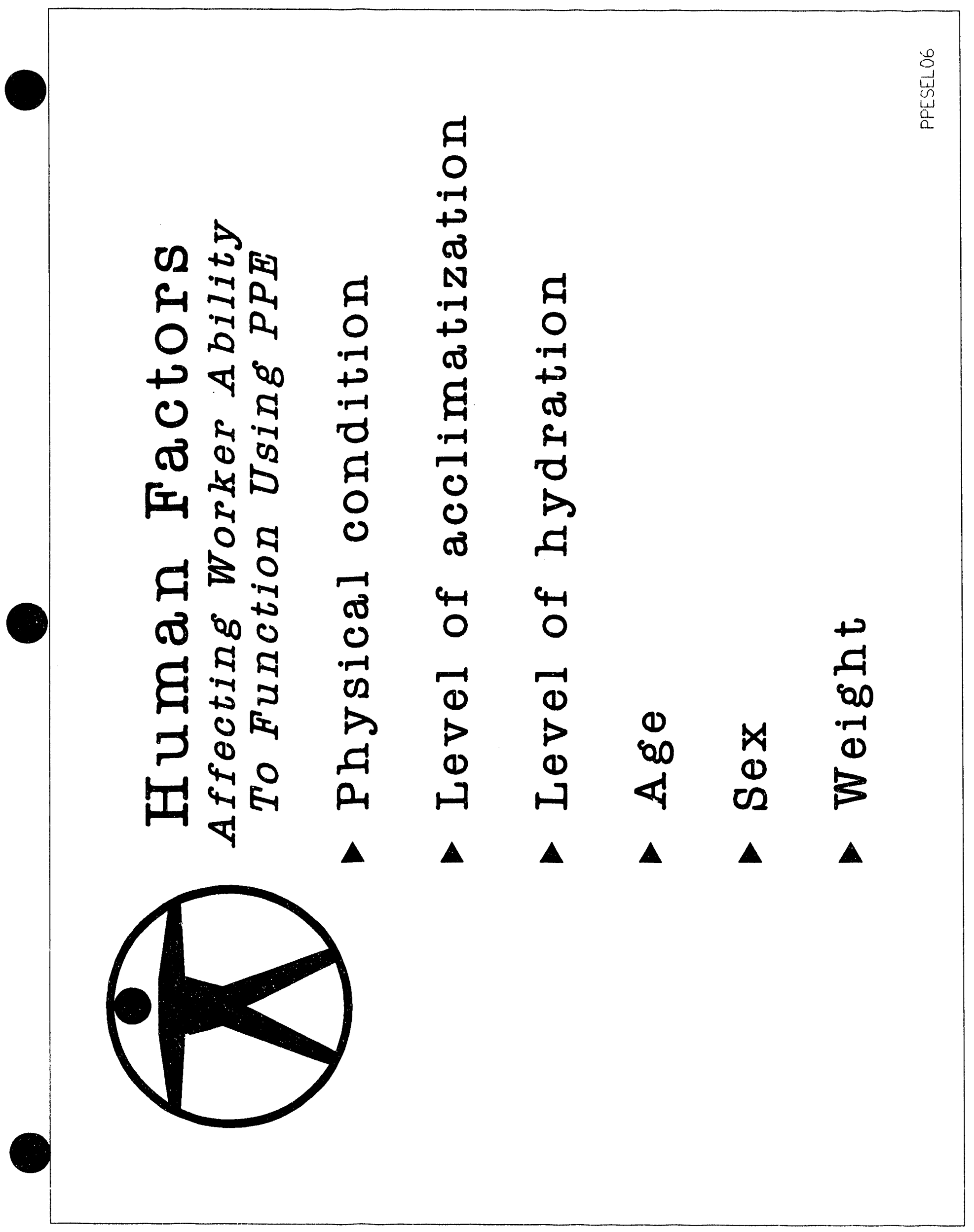




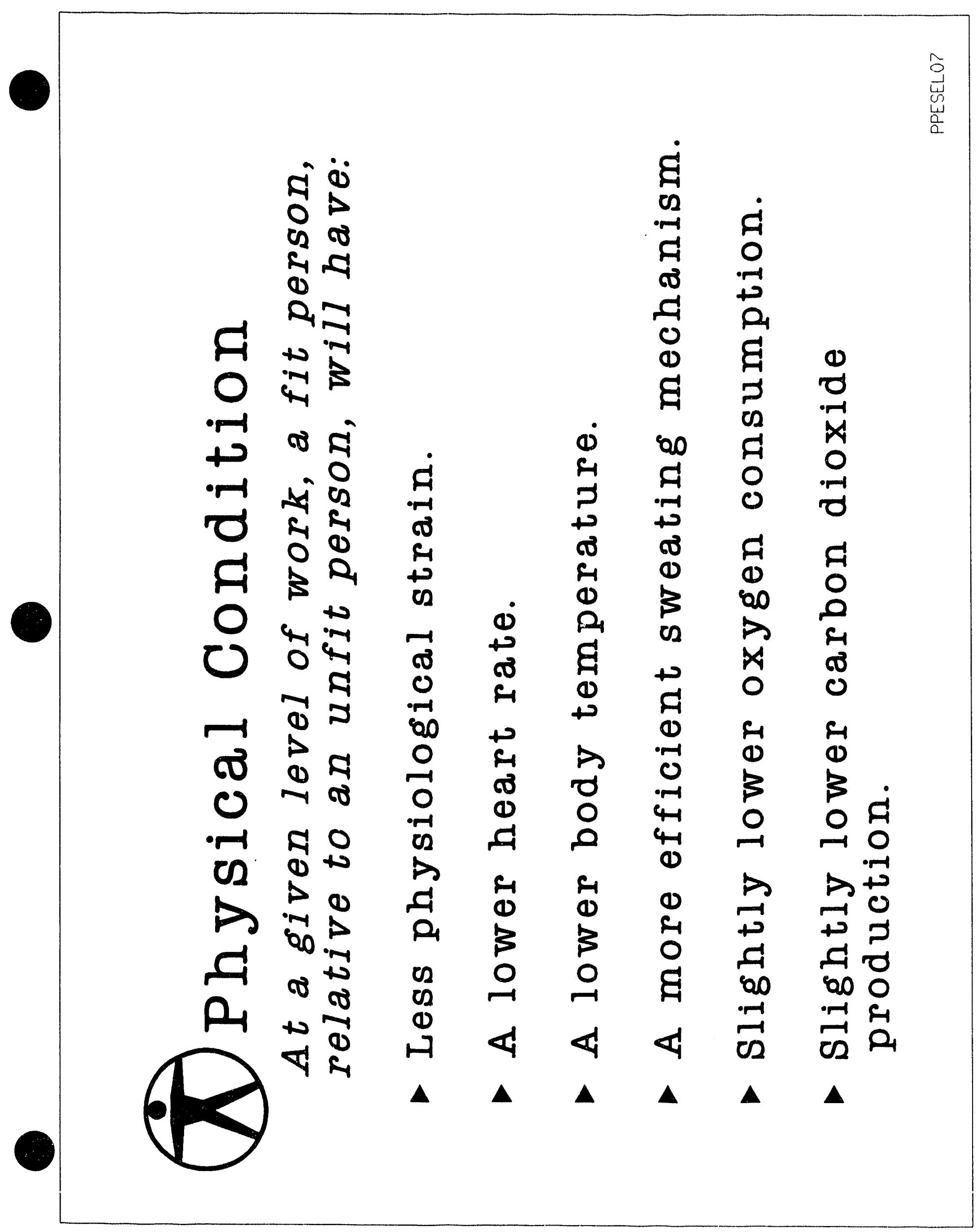




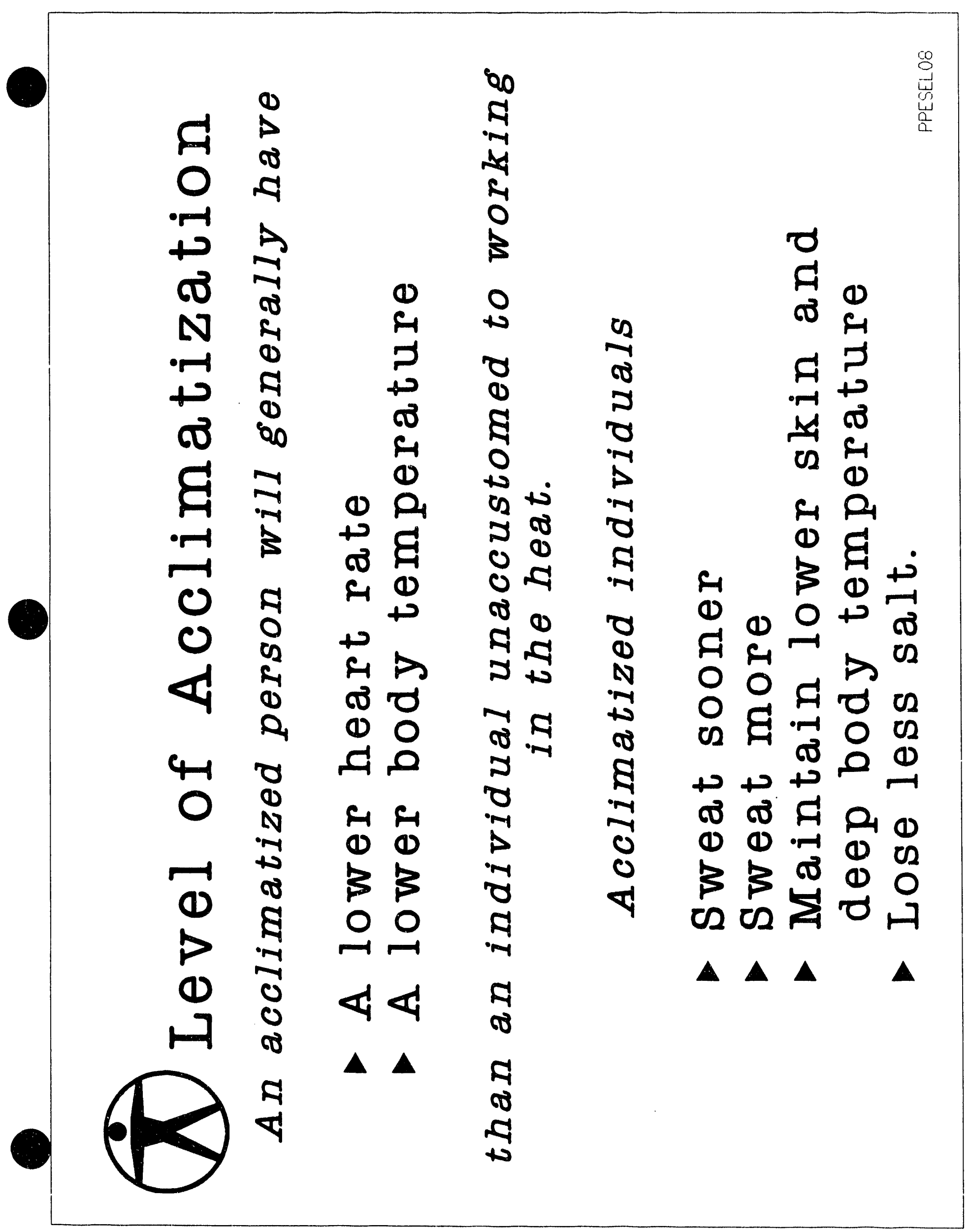




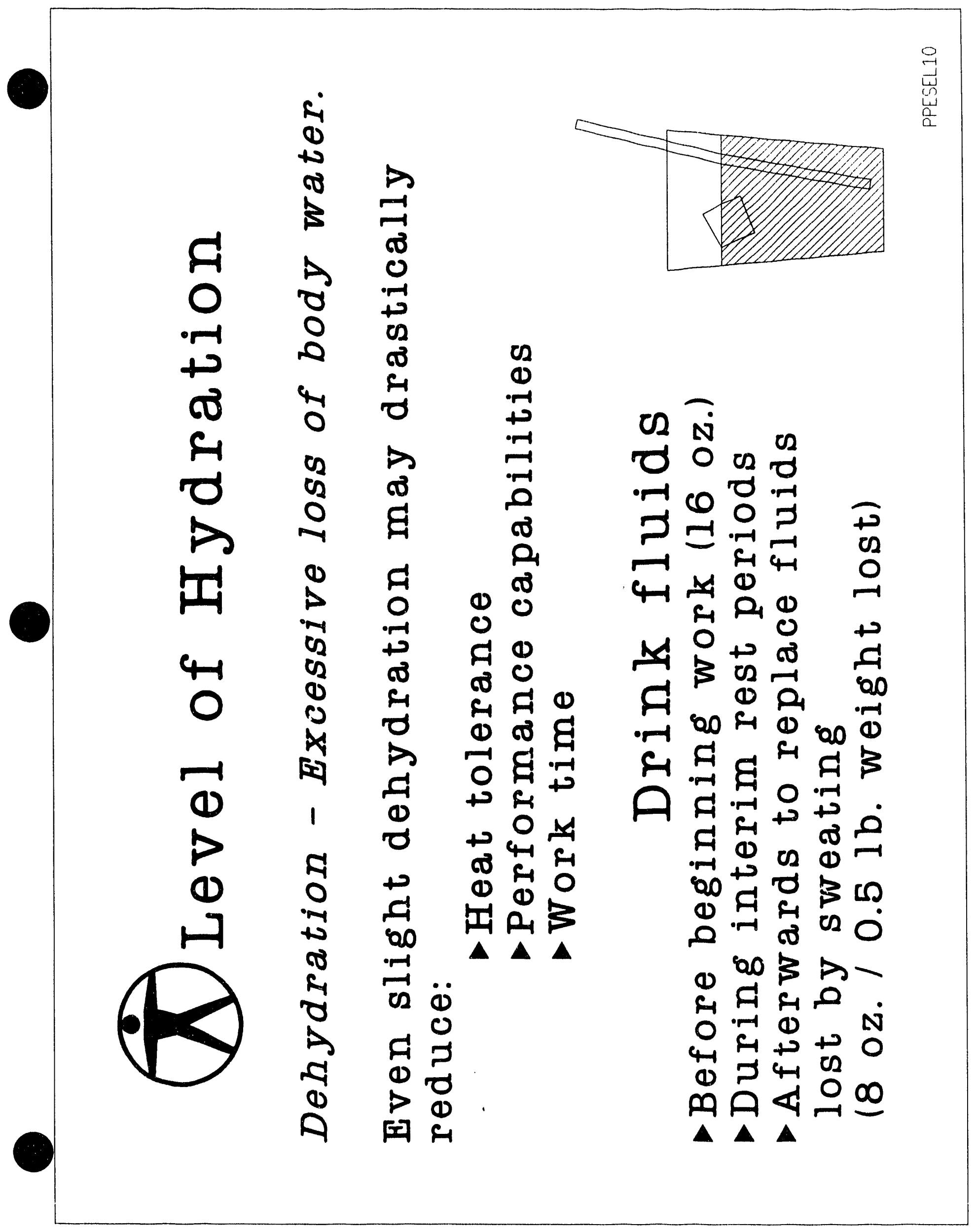




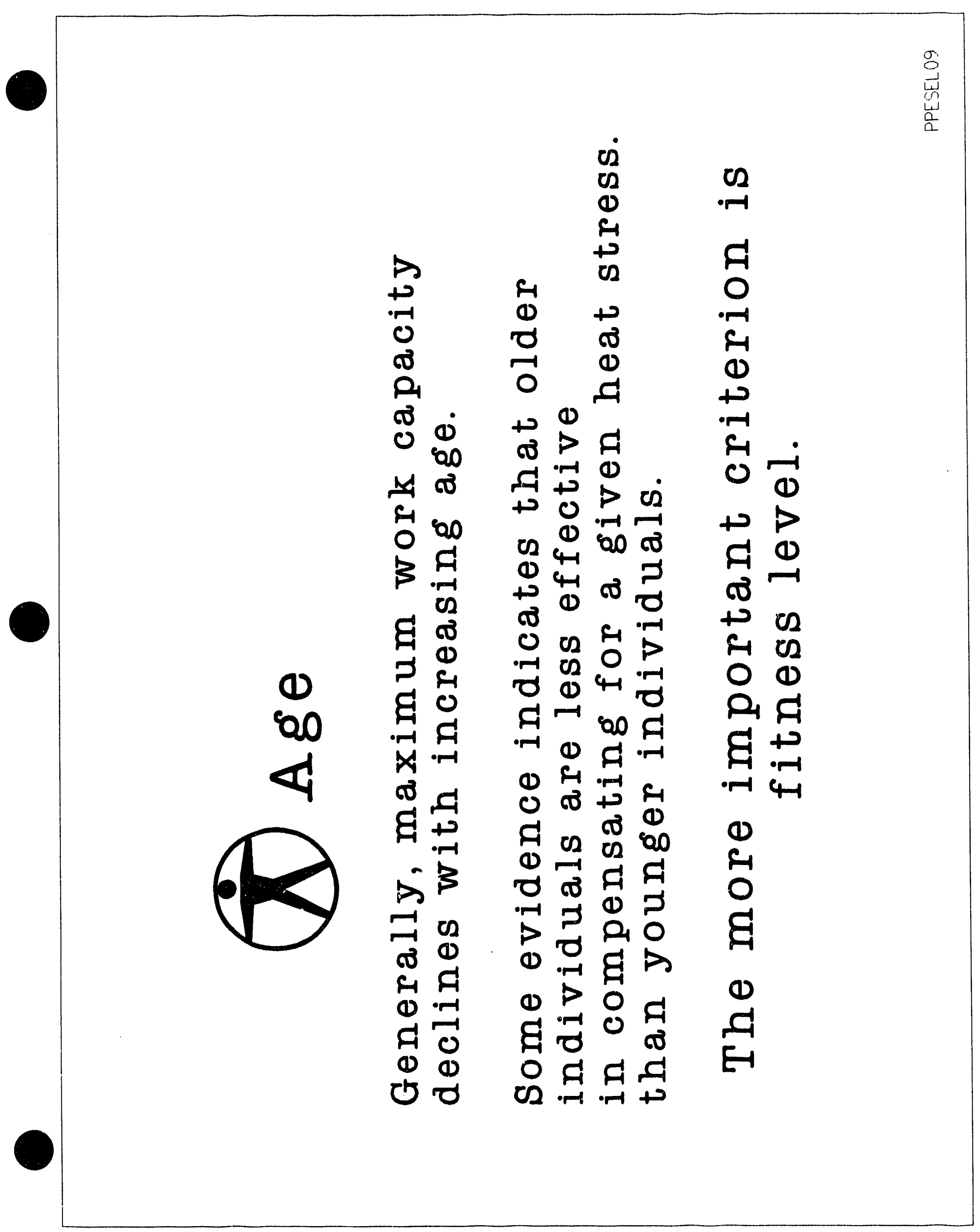




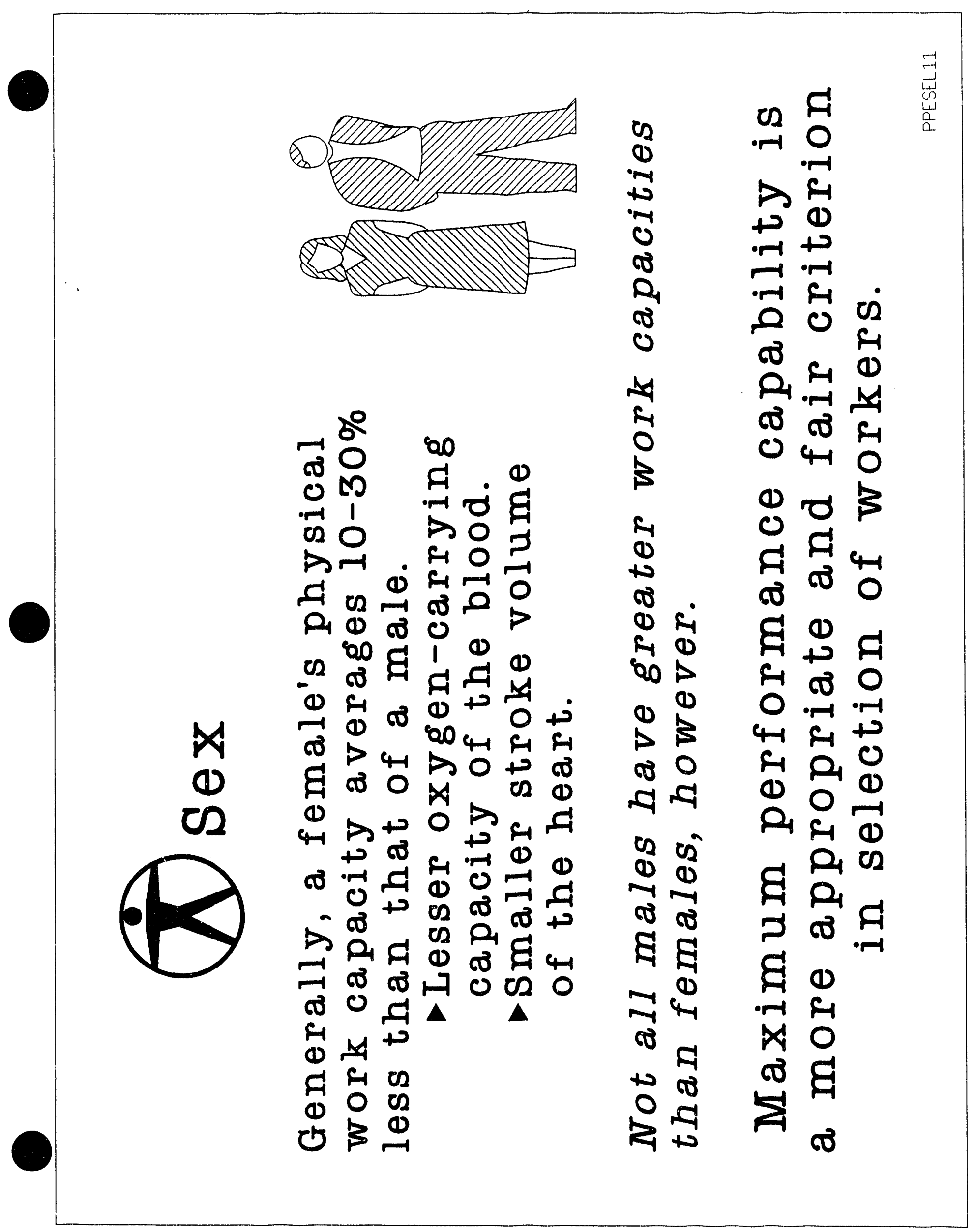




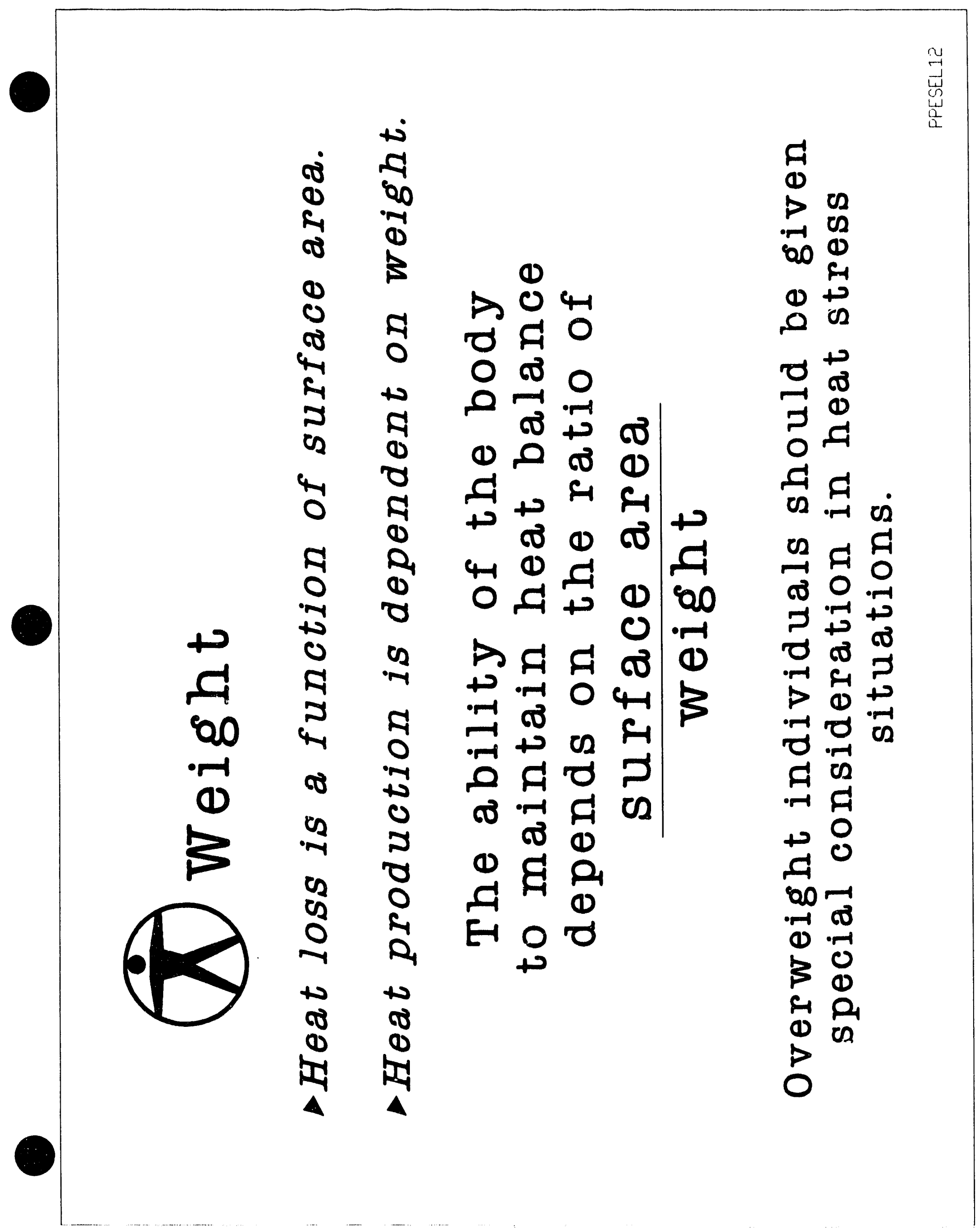


MATERIAL SAFETY DATA SHEETS EXERCISE

SCOPE

This module outlines an exercise to give participants practice in locating and using the resources available at their facility for obtaining Material Safety Data Sheets (MSDS) or equivalent sources of information. (Suggested time - 5 minutes in class; 30 minutes-1 hour out of class)

\section{PARTICIPANT GOALS}

1) Practice accessing and using the facility's primary source(s) of information on hazardous materials.

TRADE SARA/OSHA Training: March 1989 


\section{INSTRUCTOR PREPARATION}

1. Collect information on the facility's MSDS database, file system, or other facility data sources.

2. Prepare a handout explaining the location and use of this system.

3. Prepare a short work sheet on chemicals known to be present in facility waste sites for participants to complete in an out-of-class exercise. (The work sheet used by ORNL is included on page IV -4 as an example.) 

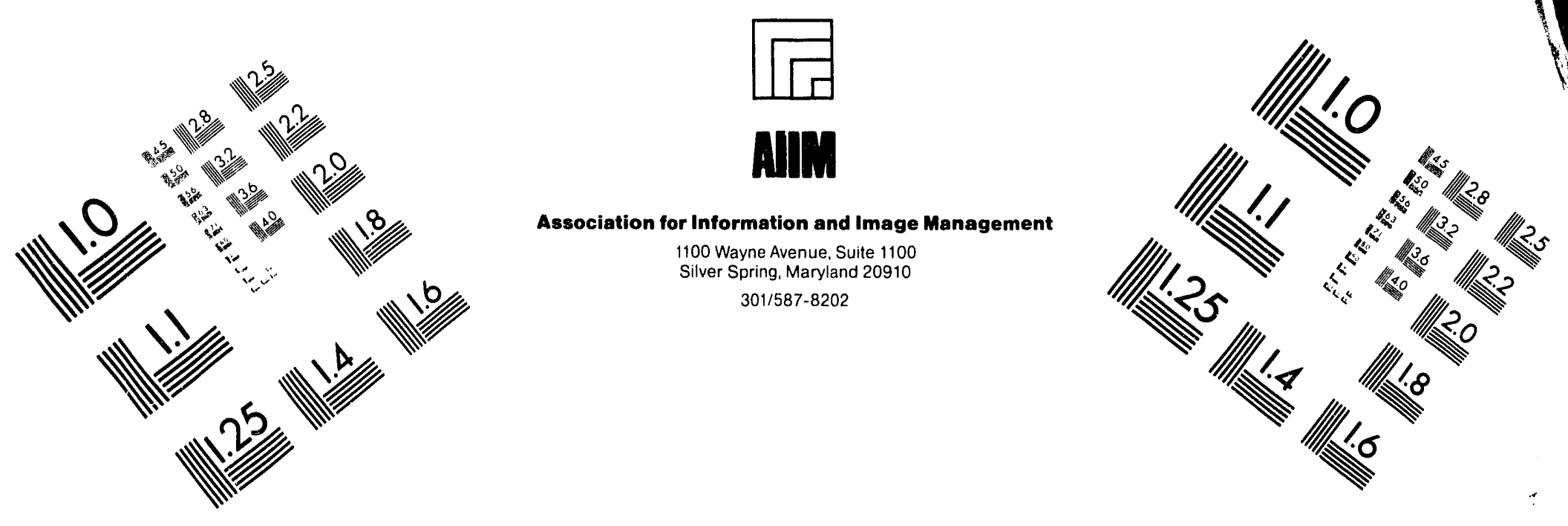

\section{Centimeter}

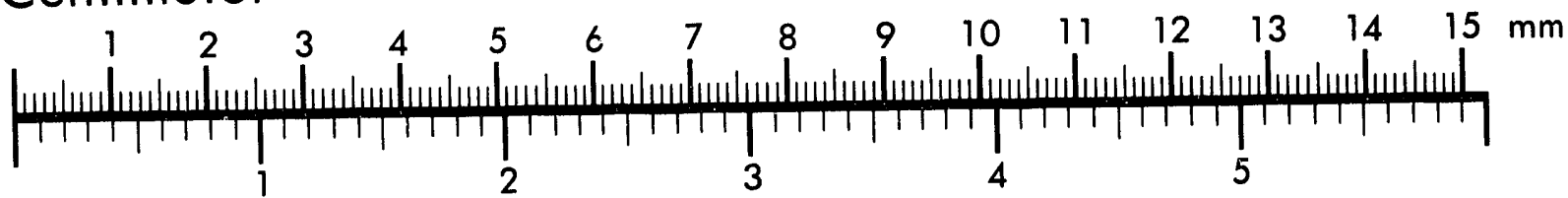
Inches
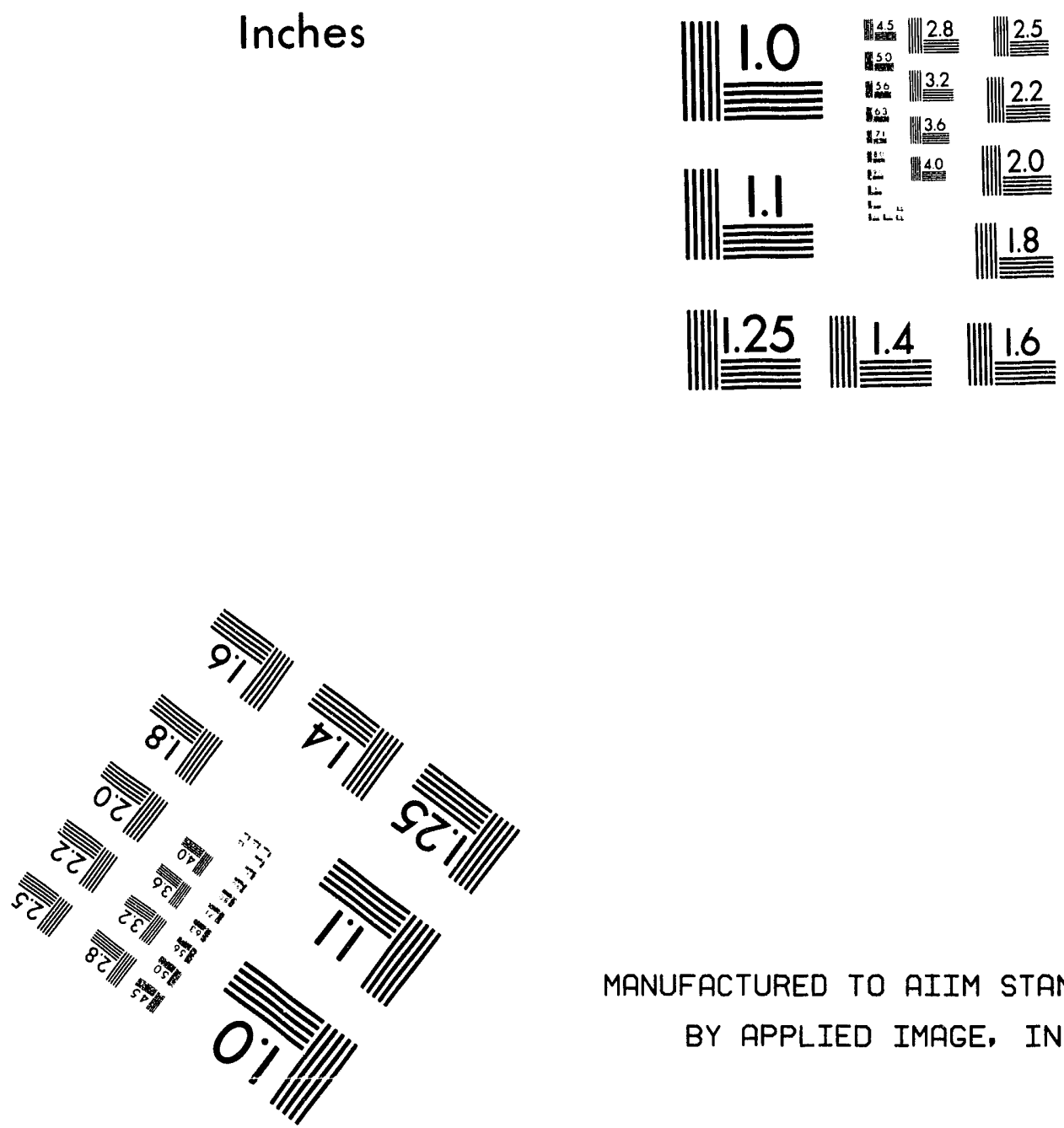

MANUFACTURED TO AIIM STANDARDS

BY APPLIED IMAGE, INC.

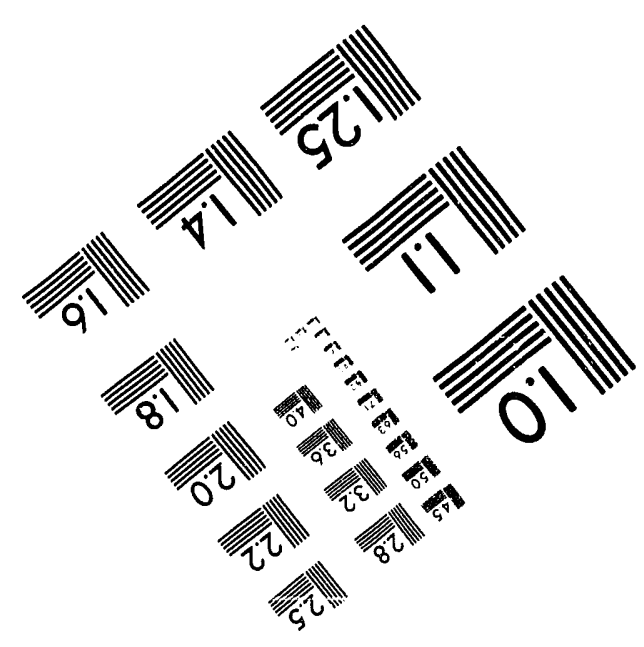




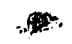
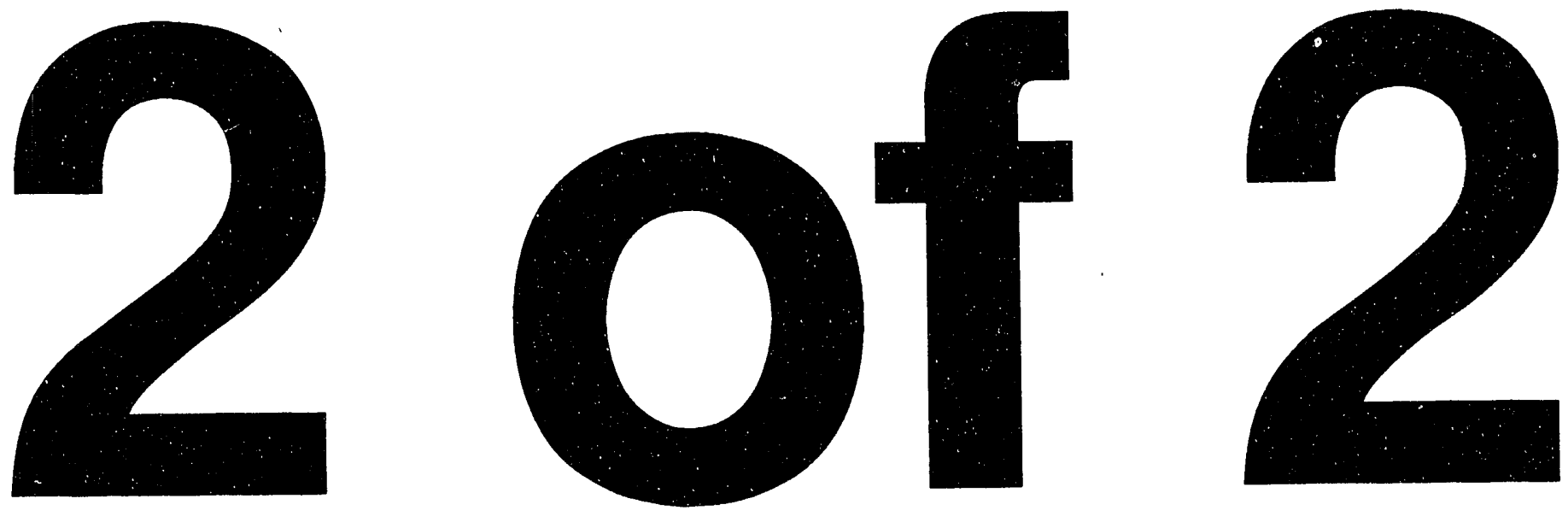


\section{INSTRUCTIONAL ACTIVITIES}

1. Briefly describe the exercise.

2. Distribute the handout on sources of information and the work sheet.

3. Give participants a time and place for returning completed work sheets. 


\section{SAMPLE}

WORK SHEET FOR USING MARTIN MARIETTA ENERGY SYSTEM'S MSDS DATA BASE

Look up benzene:

1. What are the Health Hazard Rating, Fire Hazard Rating, and Reactivity Rating of benzene?

2. What are some of the conditions to avcid while using or near benzene?

3. What is the ACGIH Threshold Limit Value for benzene?

4. Is there evidence that benzene is a human carcinogen?

5. Who is to be summoned for help in case of benzene spill or leak emergency?

6. What type of glove can be used when in contact with benzene?

Look up CASRN (Chemicail Abstract Service Registry Number) 000050-00-0:

1. What is the name of: the chemical?<smiles>[V][V]</smiles>

2. Is the chemical stable?

Look up methane:

1. How many records were found?

2. Which Item \#: is methyl mercaktan?

3. What is the DOE label? 
SARA TITLE III:

EMERGENCY PLANNING AND COMMUNITY RIGHT TO KNOW

SCOPE

This module outlines the broad elements of the Emergency Planning and Community Right-to-know Act of 1986, which is Title III of the Superfund Amendments and Reauthorization Act (SARA). The major issues addressed in SARA Title III are emergency planning, emergency notification, community right-to-know reporting on hazardous chemicals, and emissions inventory. (Suggested time - 30 minutes)

\section{PARTICIPANT GOALS}

1) List the four major areas addressed by SARA Title III.

2) State the objective of the emergency planning sections of Title III.

3) Identify persons at your facility who are responsible for SARA Title III compliance.

4) Describe the responsibility of a facility that releases an extremely hazardous substance.

5) Discuss the importance of chemical inventory reports to state and local emergency planning groups and to local fire departments.

6) State the purpose and conditions for submitting an annual toxic chemical release form. 


\section{INSTRUCTOR PREPARATION}

1. Assemble viewgraphs.

2. Prepare lecture notes.

3. Select a videotape describing SARA Title III, if desired. (ORNL chose to use "Title III: Emergency Planning and Community Right-to-Know," ITS Corporation, Marlton NJ.)

4. Prepare handout on "Overview of Title III" (page V-4).

5. Identify persons at your facility responsible for SARA Title III compliance and develop a handout with names, departments, and telephone numbers. 


\section{INSTRUCTIONAL ACTIVITIES}

1. Introduce SARA Title III, and explain that this module includes both lecture and videotape instruction. (SARA1)

2. Review the objectives for this module. (SARA2)

3. Show a videotape about SARA Title III, if desired.

4. Describe the key issues addressed by SARA Title III and distribute the handout entitled "Overview of Title III." Elicit group discussion about your facility's responsibilities. (SARA3)

5. Discuss whom to contact at your site for SARA Title III information and distribute the handout listing these contact persons. 
OVERVIEW OF TITLE III

\section{EMERGENCY PLANNING}

Objective: To improve local and state government emergency preparedness capabilities for response to chemical releases.

Responsibilities: Industrial facilities must designate a representative to participate in planning, to inform local planners of changes at the facility, and to provide information necessary to develop and implement the local emergency plan.

\section{EMERGENCY NOTIFICATION}

Objective: To provide state and local authorities with immediate and follow-up notifications of releases of extremely hazardous substances.

Responsibilities: Industrial facilities must notify the proper authorities if a release of a listed hazardous substance exceeds the reportable quantity and could result in exposure to persons off site. This notification must include the substance released, the time and duration of the release, and the health risks. Title III also requires immediate and follow-up notifications to local and state emergency coordinators.

\section{COMMUNITY RIGHT-TO-KNOW REPORTING}

Objective: To provide state and local authorities with Material Safety Data Sheets (MSDSs) defining the health and physical hazards of chemicals and to provide estimates of the quantities and locations of all hazardous chemicals at the facility.

Responsibilities: Industrial facilities must submit MSDSs or a categorized list of hazardous chemicals to the local emergency planning committee, the state emergency response commission, and the local fire department. The facility must also submit to these agencies a completed emergency and hazardous chemical inventory form that includes estimates of quantities and the on-site locations of hazardous chemicals. More detailed information must be provided at the request of the $10 \mathrm{cal}$ and state representatives or of the public planning groups.

\footnotetext{
TRADE SARA/OSHA Training: March 1989
} 
EMISSIONS INVENTORY AND TOXIC CHEMICAL RELEASE REPORTING

Objective: To make available to EPA, designated state agencies, and the public information on the estimated quantities of chemicals routinely or accidentally released into the environment as a result of normal operacions.

Responsibilities: Facilities that manufacture, process, or use specific chemicals in excess of established threshold levels must complete and submit to the EPA annual toxic chemical release forms describing the releases that occurred during the calendar year. 


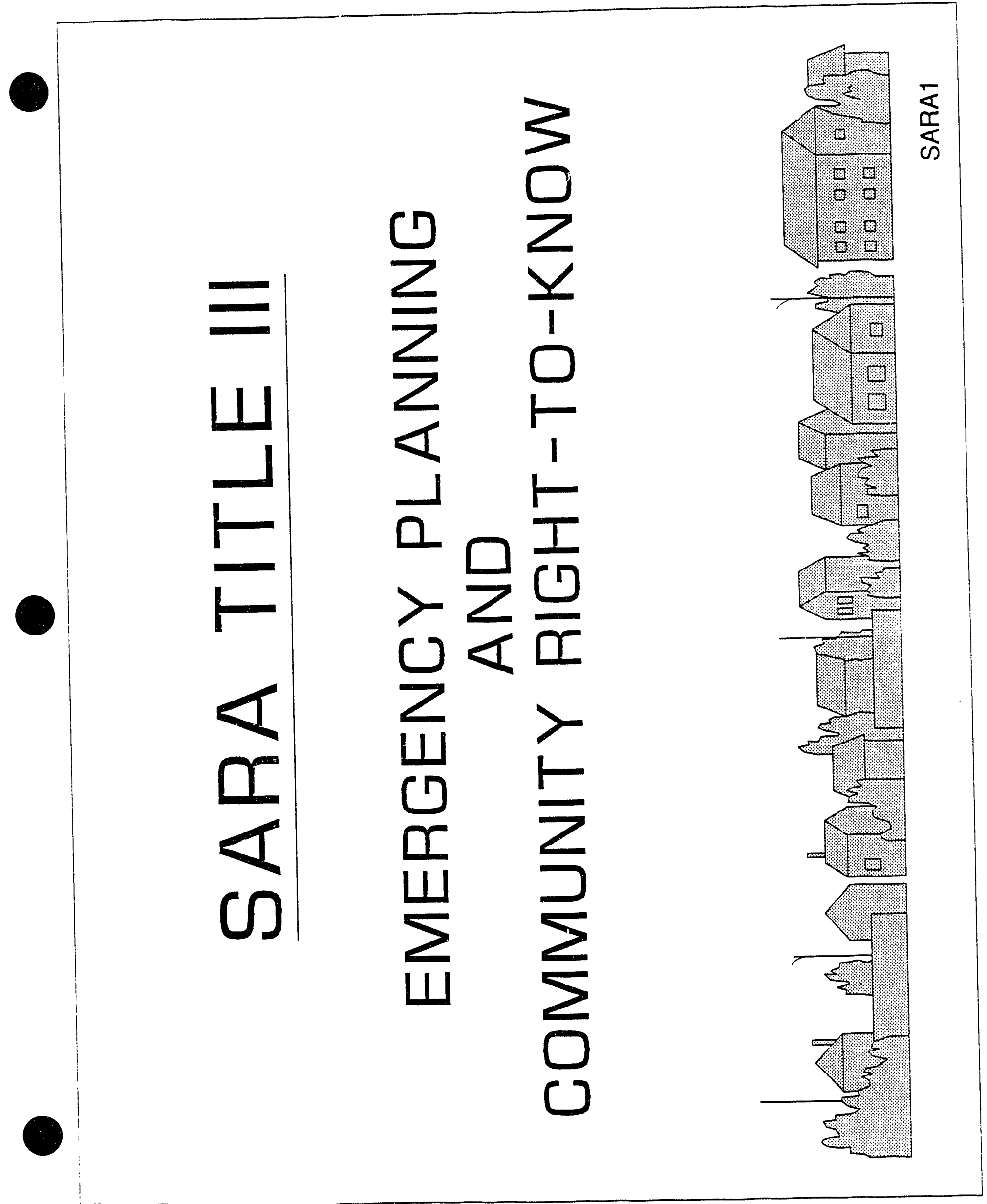




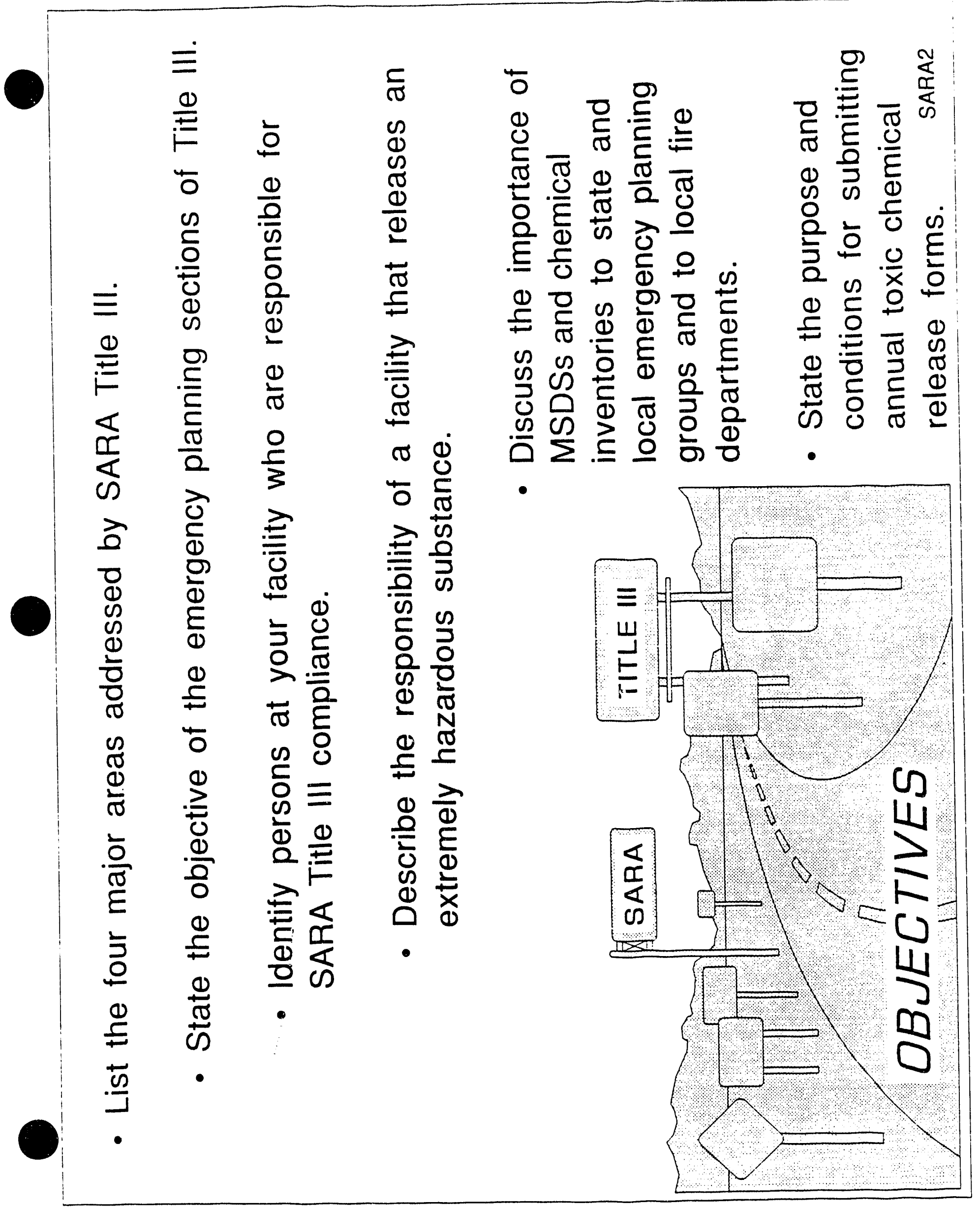




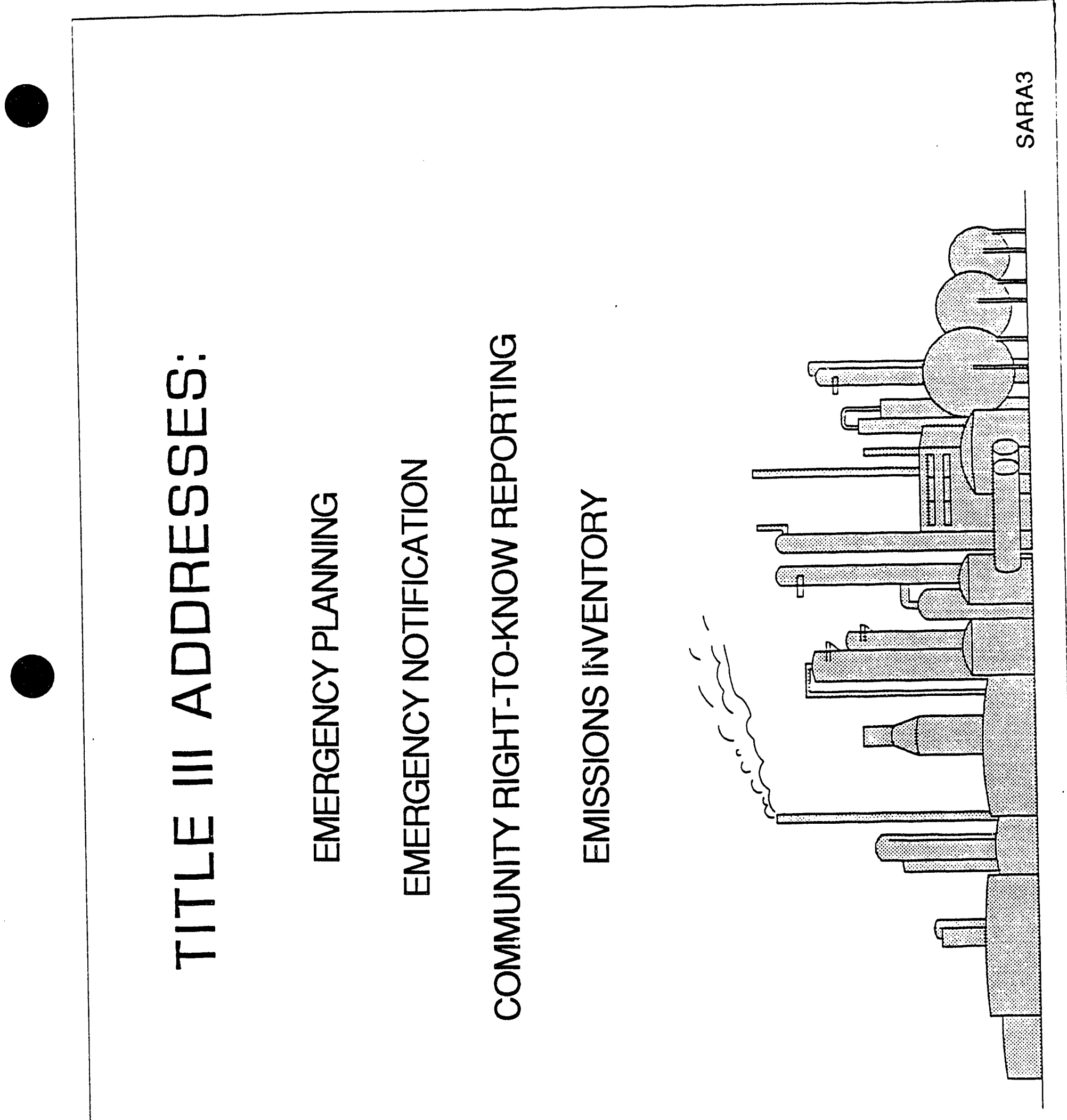




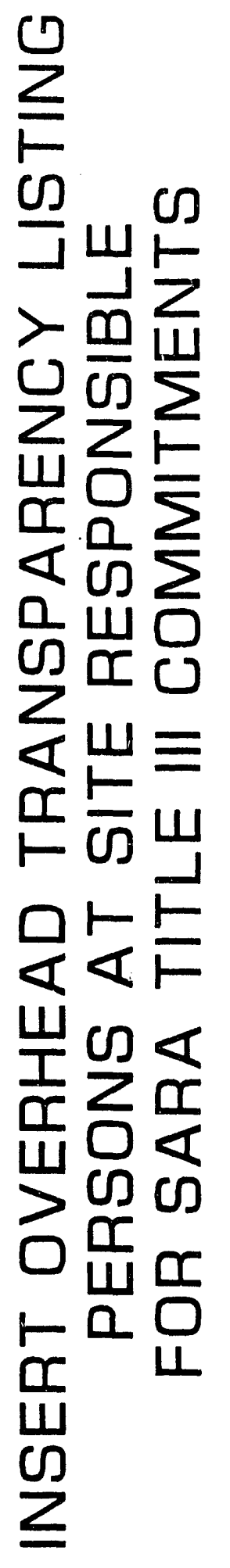

TRADE SARA/OSHA Training: March 1989 


\section{LEGAL ASPECTS OF SUPERVISION}

SCOPE

This module presents information about the personal liability provision of CERCLA/SARA. It describes corporate and personal liability, criminal and civil penalties, and the types of costs for which a responsible party may be held liable.

(Suggested time - 45 minutes)

\section{PARTICIPANT GOALS}

1) Distinguish between corporate and personal liability.

2) Distinguish between criminal and civil penalties.

3) Identify types of costs covered. 


\section{INSTRUCTOR PREPARATION}

1. Assemble viewgraphs.

2. Prepare lecture notes.

3. Determine the legal policy criteria your facility uses such as a DOE policy, site-specific policy, or no written policy, and present to participants.

4. Determine the names of individuals to whom participants should go to receive additional information about legal aspects of supervision, and prepare handouts listing these names, if desired. 


\section{INSTRUCTIONAL ACTIVITIES}

1. Introduce the subject by explaining about the growing body of environmental law that contains references to personal liability: the Resource Conservation and Recovery Act of 1976 (RCRA), the Comprehensive Environmental Response, Compensation, and Liability Act of 1980 (CERCLA or Superfund), the Superfund Amendments and Reauthorization Act of 1986 (SARA), and the most recently passed version of the Price-Anderson Act governing liability of nuclear facilities.

(LEGAL 1)

2. Review the objectives. Point out the legal definitions and how they are shaped as the laws are interpreted by different courts over time. (LEGAL 6)

3. Define criminal and civil penalties, as given in the SARA/CERCLA laws. Explain that criminal penalties often include incarceration and can also result in fines, and that civil penalties are more likely to be fines. Give examples where possible (at this point, these cases are often examples from the 1976 RCRA law because these are now reaching the courts). Note any rulings from contractor legal staff if available.

(LEGAL 2)

4. Discuss the scope of liability as it extends to individuals who exercise personal control over or are actually involved in treatment, transport, or disposal of hazardous wastes. Note that the individual does not have to own the hazardous waste or the waste facility or to hold a corporate office to be liable.

(LEGAL 3)

5. Ask participants how this individual liability relates to their daily work functions. Discuss their responses, and 1 ist the questions they would like clarified by corporate or government legal staff. Review again how the courts shape these definitions over time. Discuss why lawmakers and courts have started making individuals and not just corporations liable for human and environmental harm. 
6. Discuss the concept of willful neglect. Define negligence as doing or omitting an act which a person owes to another by virtue of legal duty imposed upon him or her by law, thereby causing injury to person or property. Point out that negligence deals with acts not intended to inflict injury and that if there is intent to inflict injury, then the case becomes one of criminal law. Note also that negligence does not have to be proven by the plaintiff in a case involving violation of statutory law such as SARA Title I, Section 126, which deals with hazardous waste worker training.

7. Review the three types of costs defined in the laws: governmental response costs (where the government takes action to resolve the problem), private response costs (where a private concern is delegated to resolve the problem but is not the liable party or perhaps not the only liable party), and damage to natural resources (where the environmental damages may be irreversible or very long lasting and where compensation is awarded to the injured parties).

(LEGAL 4)

8. Ask participants if they can think of situations where each of these types of costs might be incurred in their work. List their responses and discuss. Reiterate the growing emphasis within the DOE system and other federal agencies on being responsible to all federal, state, and local laws and regulations.

9. Review the limited defenses as spelled out in the laws: acts of God, acts of war, and acts or omissions of a third party NOT under contract. (LEGAL 5)

10. Discuss with participants the likelihood of SHARED LIABILITY with any subcontractors, shippers, etc., who might be dealing with them in the treatment, transport, or disposal of hazardous wastes (including environmental remedial action).

11. Summarize the module by reviewing the objectives. (LEGAL 6) 


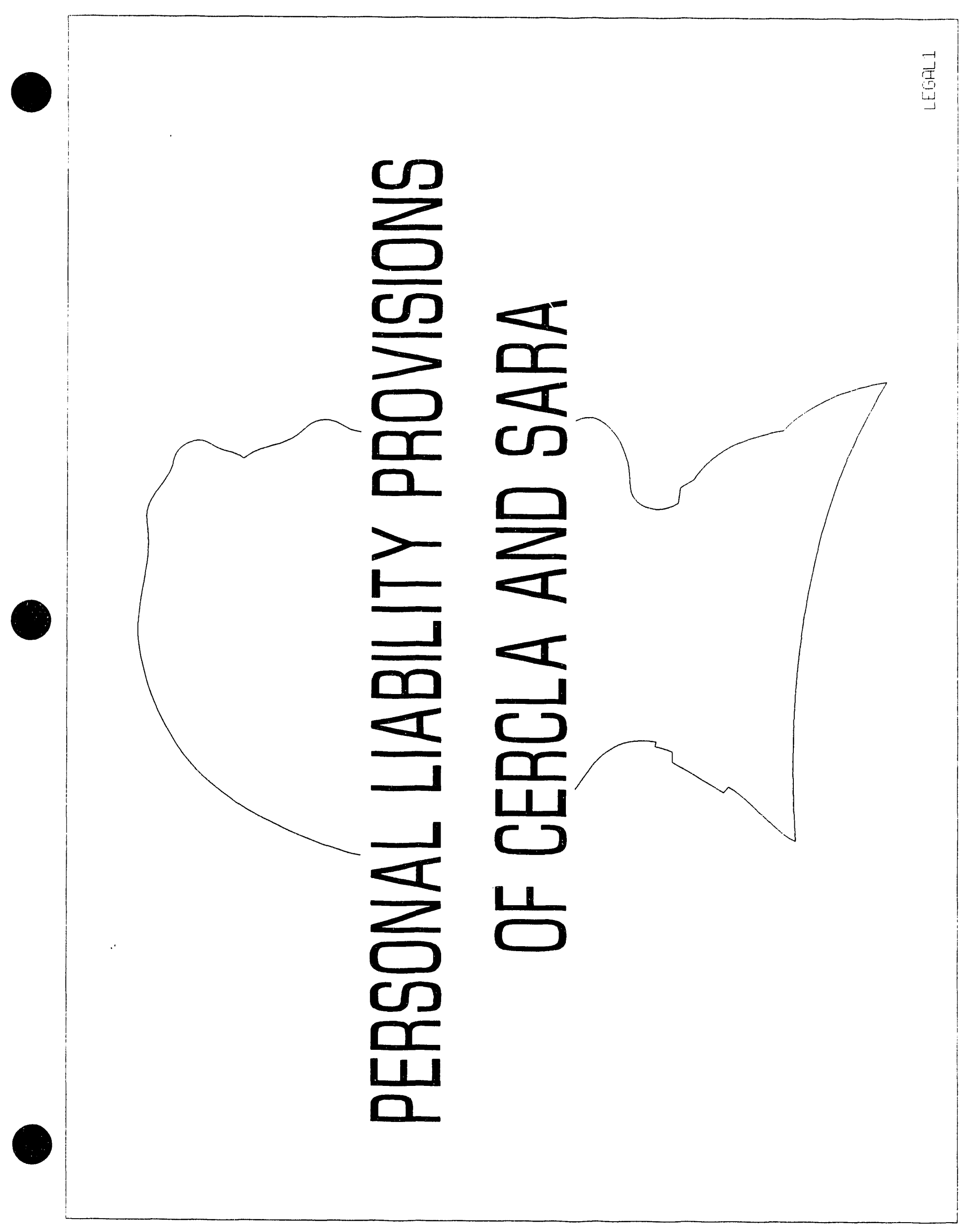




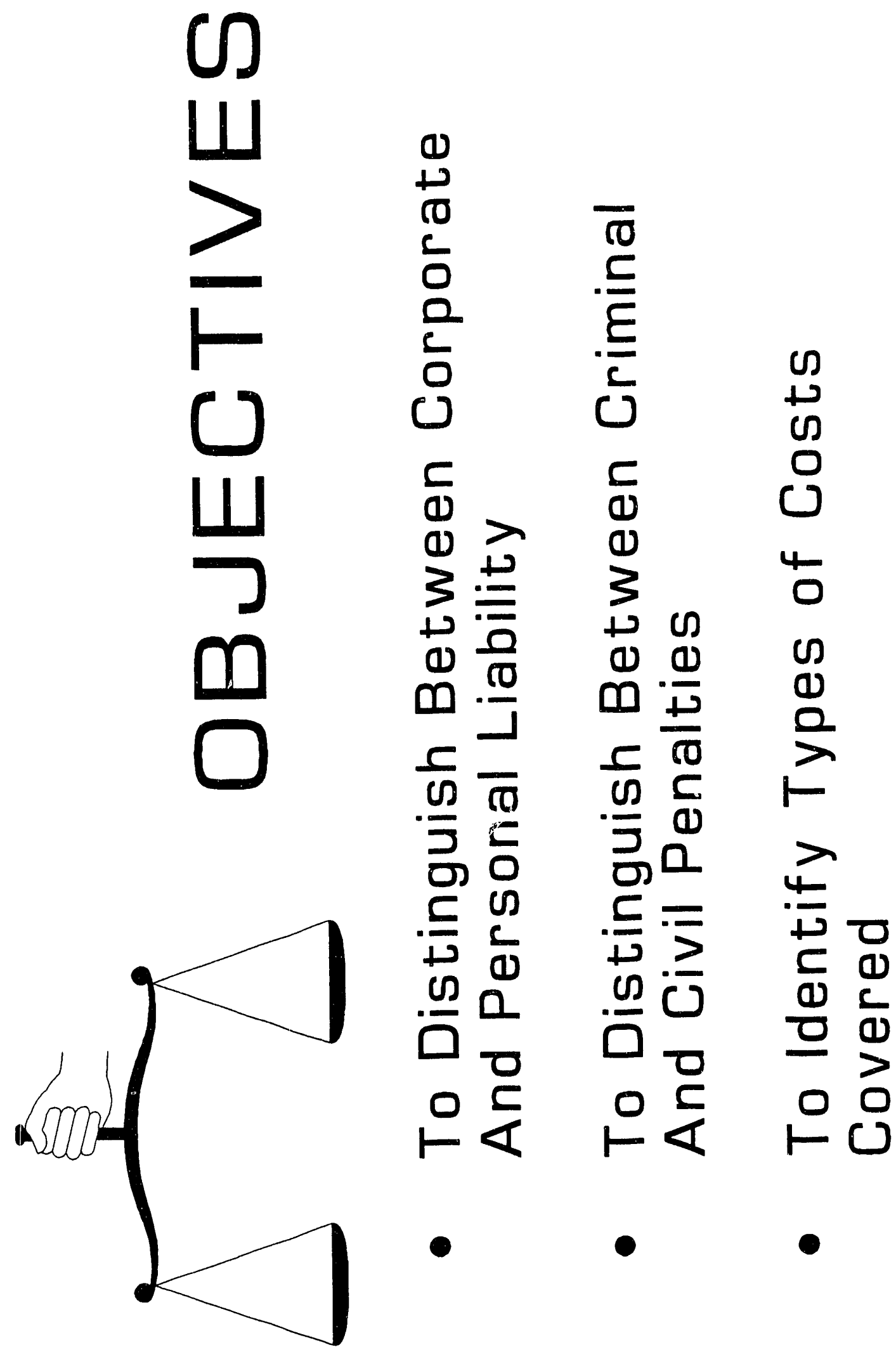

$V I-6$ 


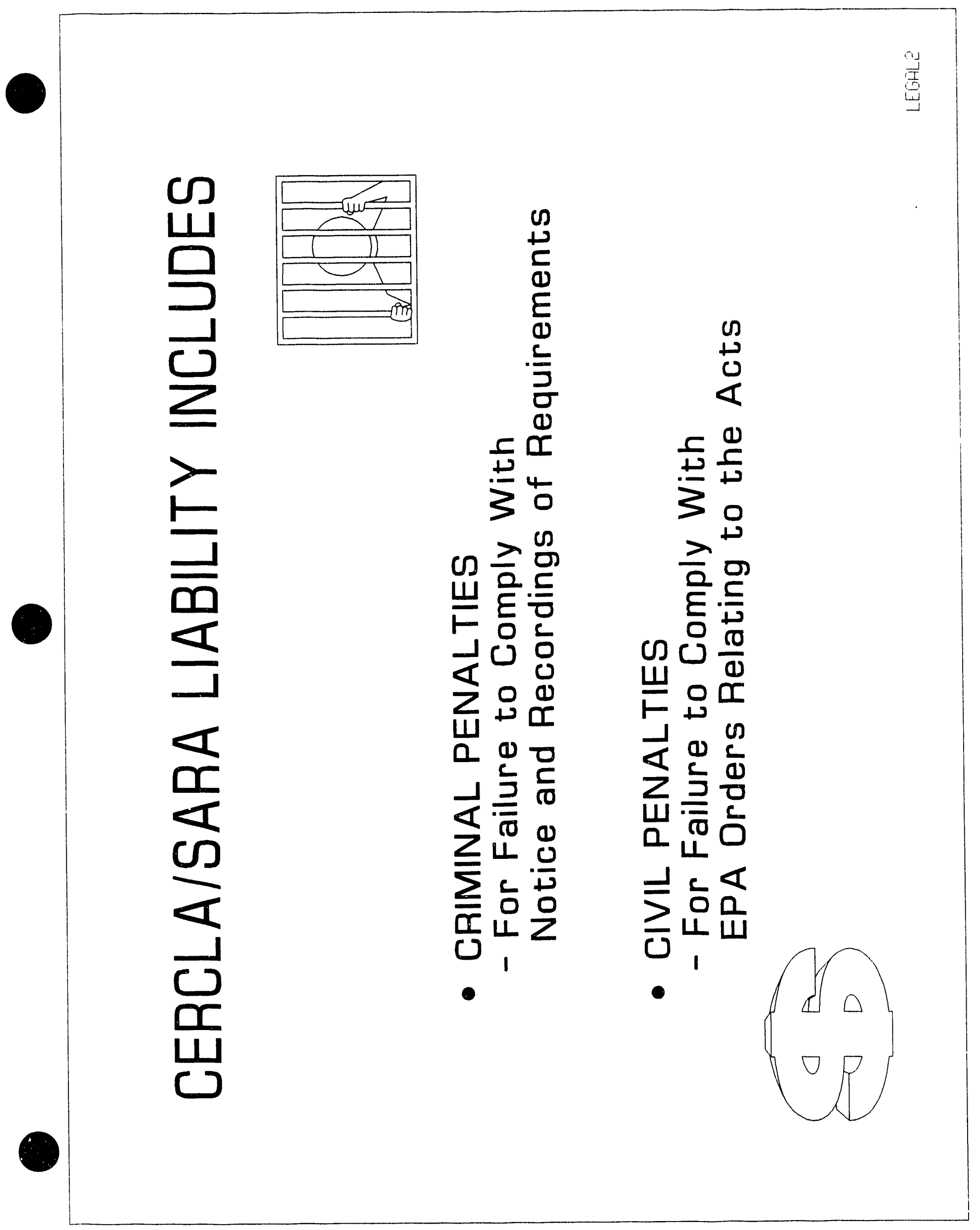




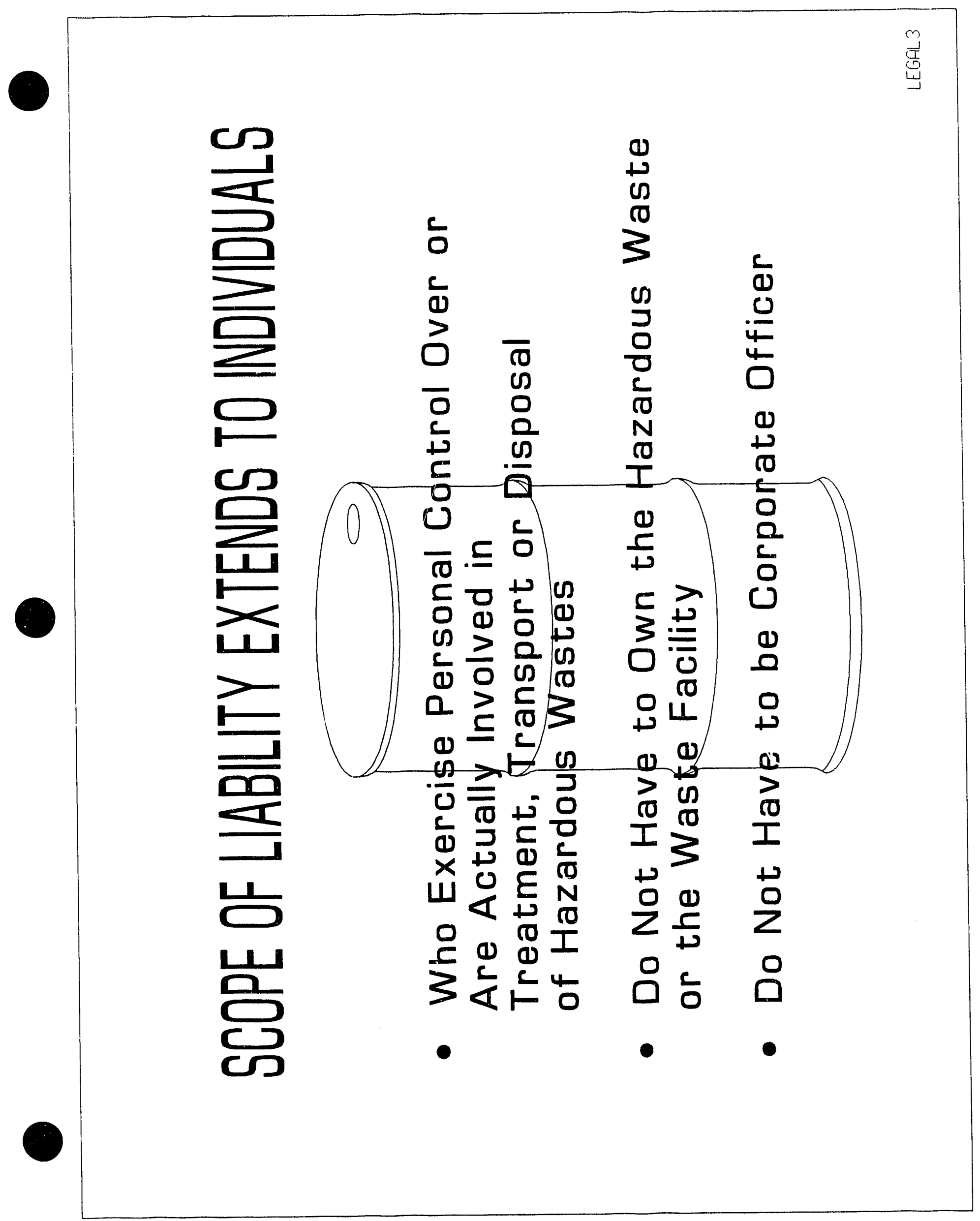




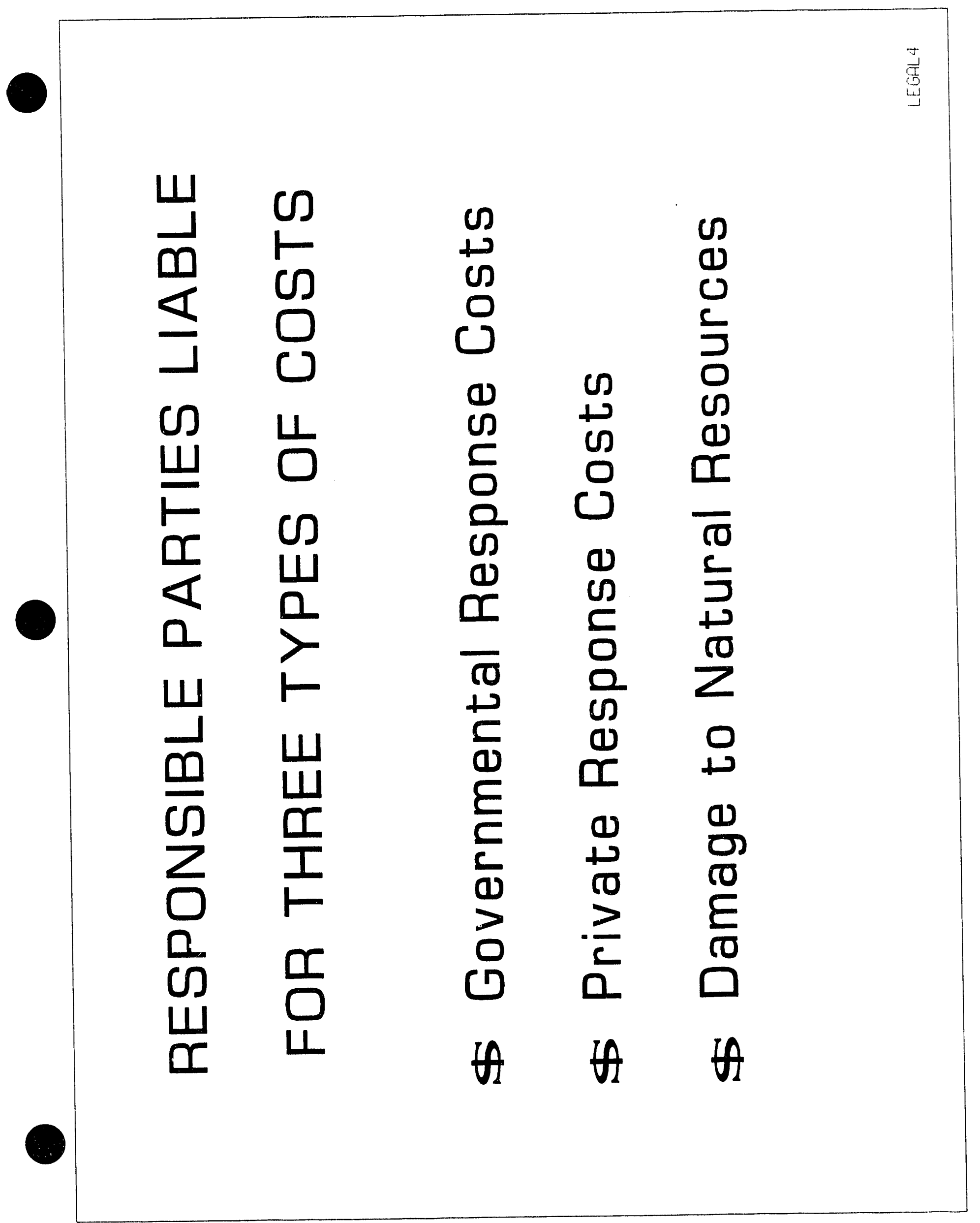

VI-9 


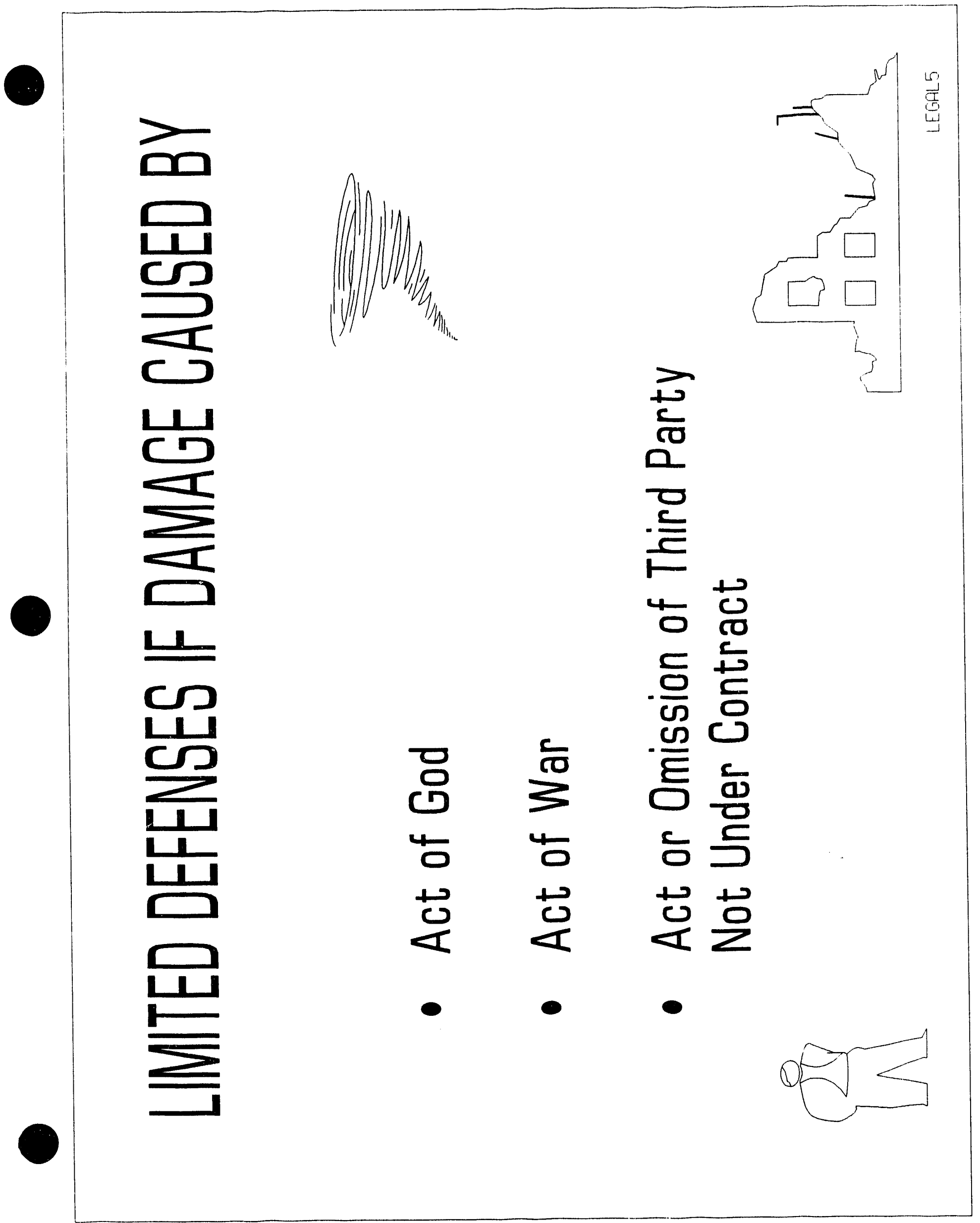


ON-THE-JOB TRAINING SKILLS

SCOPE

This module describes the basic process of on-the-job training (OJT), lists several advantages and disadvantages of OJT, and explains why the first-line supervisor is usually the best-qualified person to conduct OJT and to evaluate employee training.

(Suggested time - 1 hour)

\section{PARTICIPANT GOALS}

1) Define performance-based training.

2) Define on-the-job training.

3) Explain how OJT differs from job experience.

4) Describe the steps in a very basic OJT process.

5) Describe the roles of the instructor and trainee in OJT.

6) List two advantages and disadvantages of OJT.

7) Describe why it is desirable to use the first-line supervisor as the $\mathrm{OJT}$ instructor and evaluator.

8) Describe the eight common training errors committed by first-line supervisors. 


\section{INSTRUCTOR PREPARATION}

1. Prepare flip chart. (The text of the flip chart developed and used by ORNL is included on pages VII-5 to VII-9.)

2. Prepare lecture notes.

3. Assemble handout pages VII-10 to VII-24. Include site-specific OJT checklists. 


\section{INSTRUCTIONAL ACTIVITIES}

1. Introduce the subject by reviewing the SARA regulations that require "three days of actual field experience under the direct supervision of a trained and experienced supervisor..." [29 CFR 1910.120 (e)(2)]. [Flip chart \#1]

2. Review the objectives. [FC\#2 and FC\#3]

3. Ask participants for their definition of performance-based training. Turn to FC\#4 and discuss.

4. Ask participants for their definition of on-the-job training. Turn to FC\#5 and discuss.

5. Ask participants, "What is the difference between informal OJT and formal OJT?" [FC\#6]

6. Ask participants, "If I were to assign you to work with an experienced operator or technician for one week, would you be receiving OJT?" Discuss their responses. Reemphasize that OJT must be auditable.

7. Review the elements of OJT. [FC\#7]

8. Discuss each of the basic steps of the OJT process. [FC\#8]

9. Review the roles of the trainee and the instructor during OJT. [FC\#9]

10. Ask participants to turn to the pages in their handouts titled "Advantages of OJT" and "Disadvantages of OJT" and list advantages and disadvantages.

11. Record advantages on FC\#10 and disadvantages on FC\#11. Discuss.

12. Discuss the first-line supervisor as the OJT instructor. [FC\#12]

13. Discuss the qualifications of the OJT instructor. [FC\#13]

14. Ask participants, "Why is the first-line supervisor usually the best qualified person to do the OJT instruction?" Record their responses on FC\#14. 
15. Discuss the common errors committed during OJT instruction. [FC\#15]

16. Review the tips for successful OJT instruction. [FC\#16]

17. To summarize, review the objectives on FC\#2 and FC\#3.

18. Discuss the examples of OJT checklists that are included in the handout. 


\section{Text for Flipcharts}

$$
\text { VII-5 }
$$




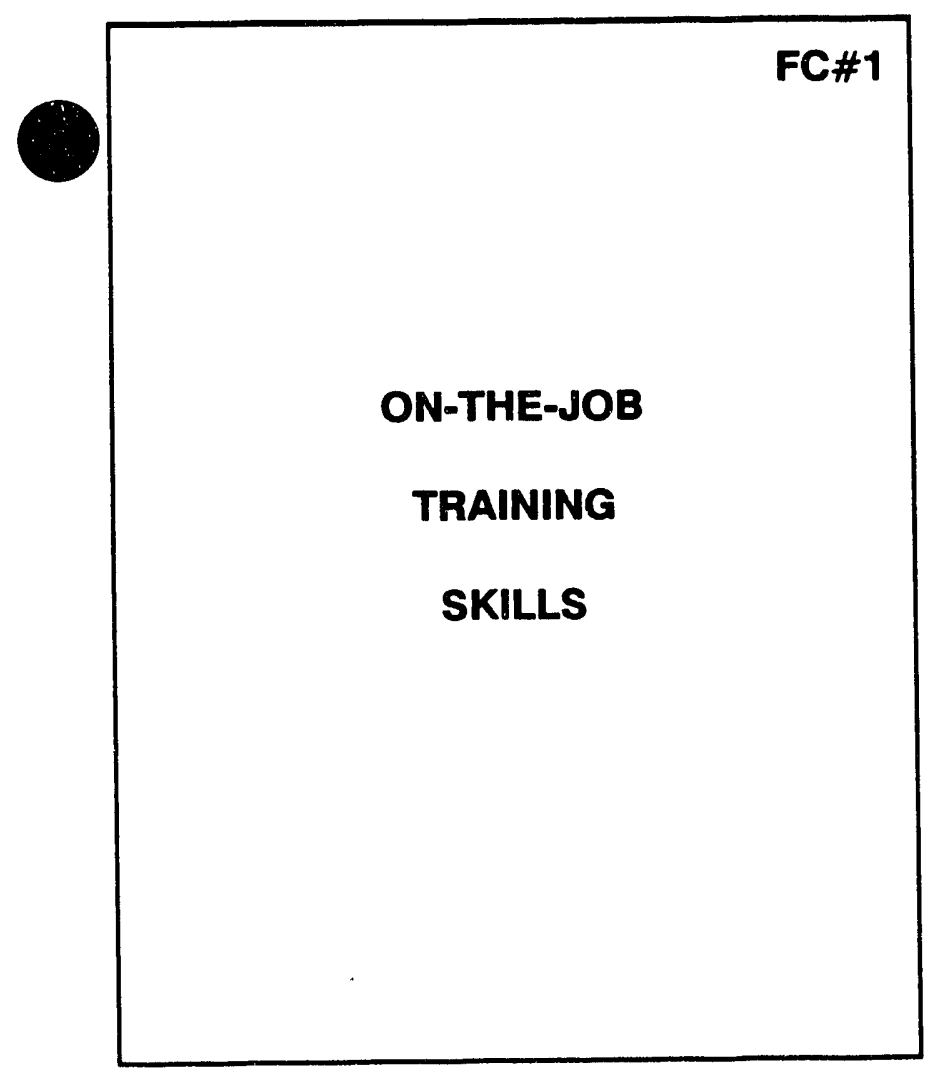

TERMINAL OBJECTIVE

OJT Instructor will describe basic OJT process, list several advantages and disadvantages of OJT, and explain why first-line supervisor is usually best qualified person to conduct OJT and evaluate employee learning.

\section{FC\#3}

ENABLING OBJECTIVES

1. Define performance-based training

2. Define on-the-job training

3. Explain how OJT differs from job experierice

4. Describe steps in basic OJT process

5. Describe roles of instructor and trainee in OJT

6. List two advantages and disadvantages of OJT

7. Describe why first-line supervisor is best OJT instructor

8. Describe eight common errors in training by first-line supervisor 


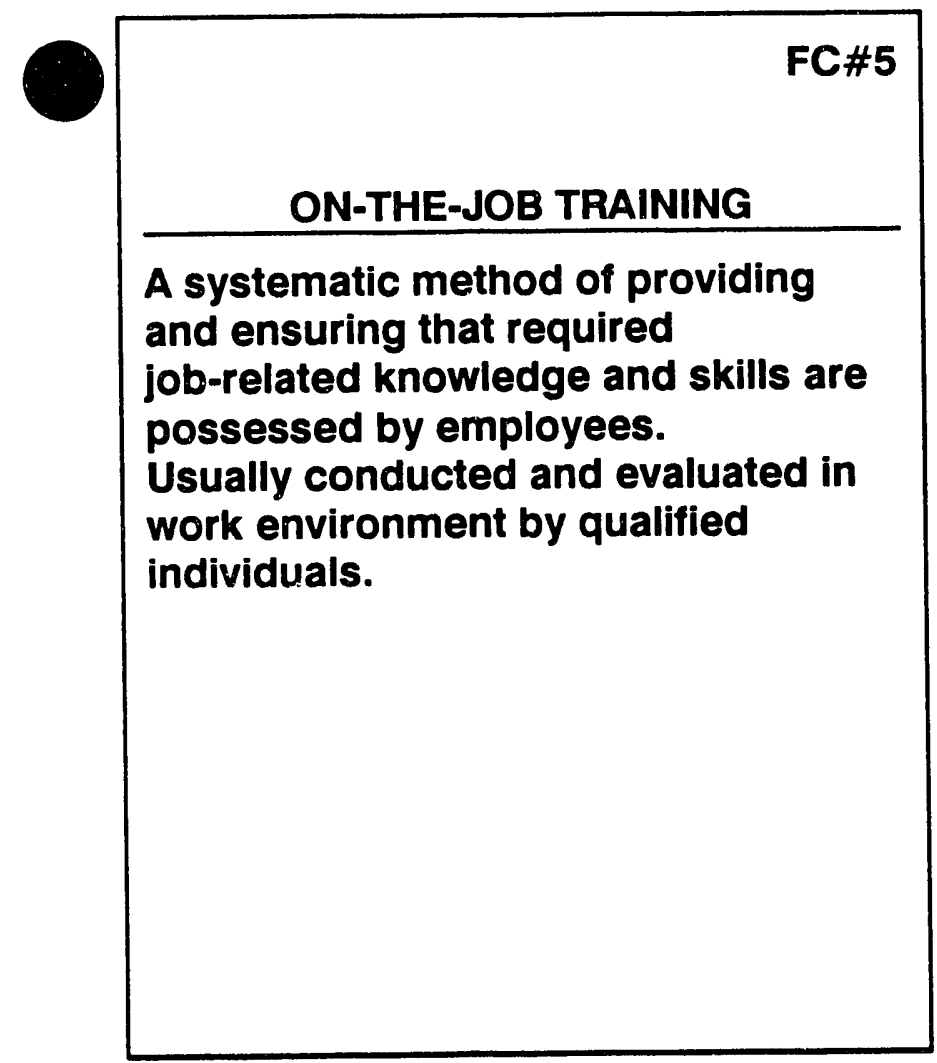

INFORMAL OJT

VERSUS

FORMAL OJT

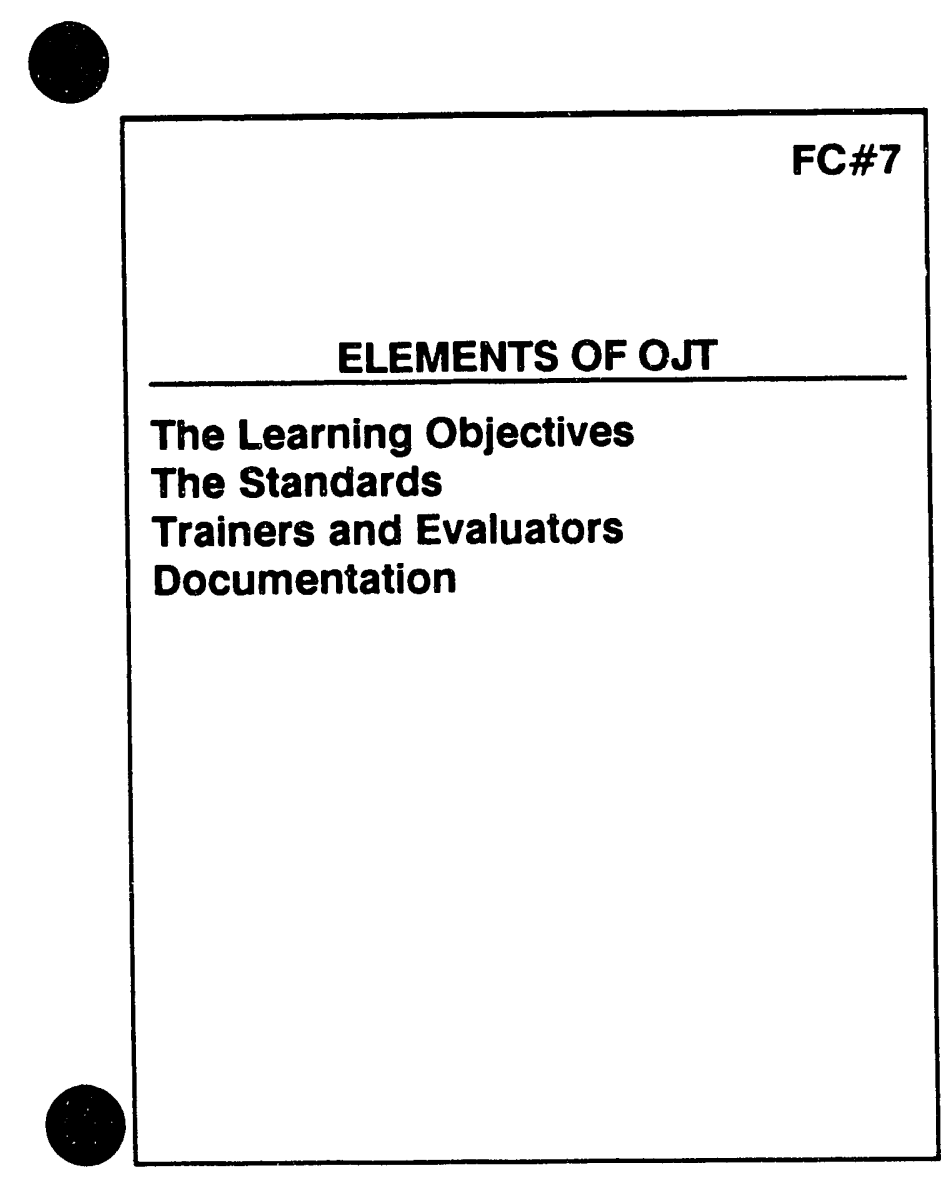

FC\#8

\section{BASIC OJT PROCESS}

introduction

Explanation

Demonstration

Practice under Supervision

Conclusion

Documentation

Evaluation 


\begin{tabular}{|l|}
\hline \\
ROLE OF TRAINEE AND INSTRUCTOR \\
\hline Trainee \\
Listen/take interest \\
Observe \\
Ask questions/discuss \\
Perform enabling objectives \\
Exercise/repetition \\
Perform terminal objective \\
Instructor \\
Motivate/orient \\
Explain \\
Demonstrate \\
Monitor/assist \\
Question/discuss \\
Evaluate/repeat
\end{tabular}

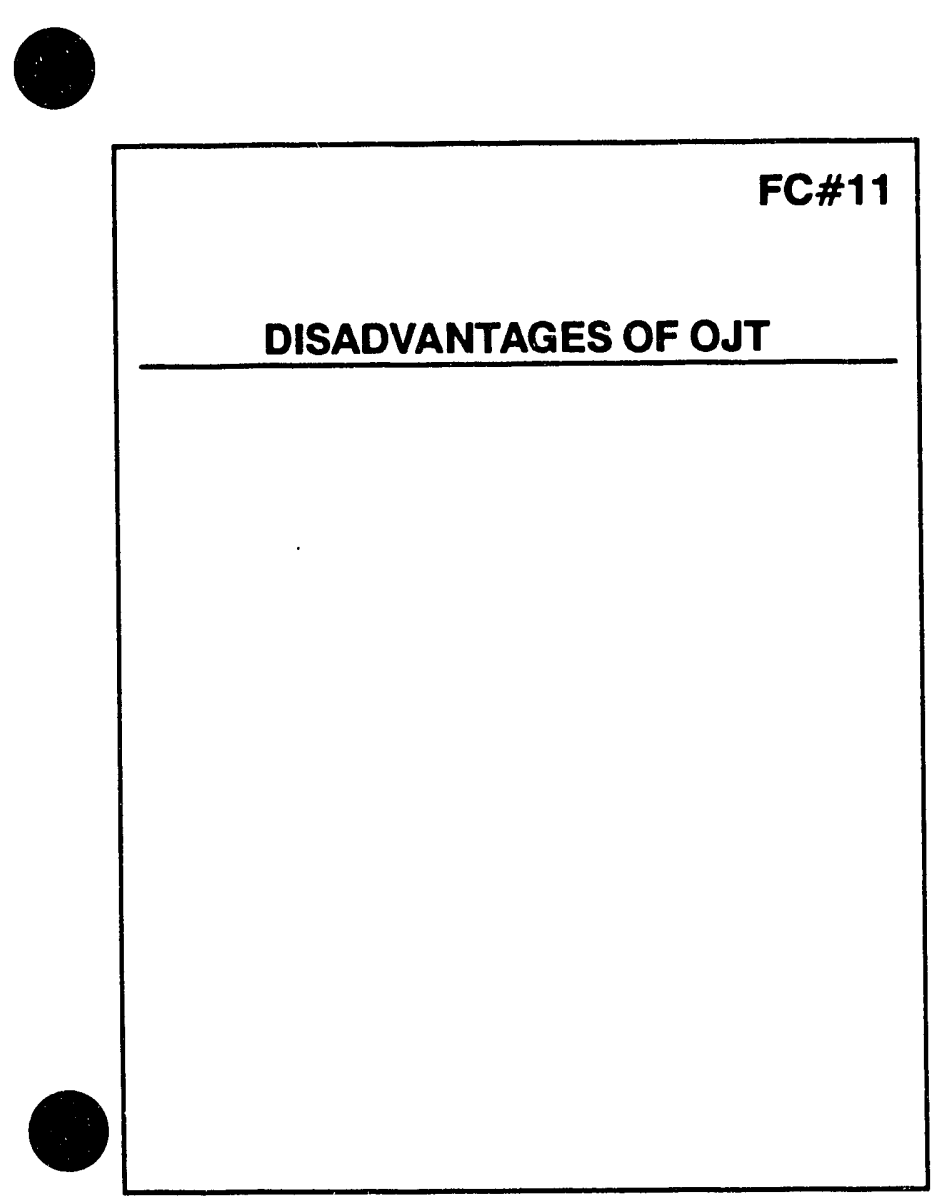

FC\#12

THE FIRST-LINE SUPERVISOR

AS THE

OJT INSTRUCTOR 


\begin{tabular}{l}
\hline FC\#13 \\
INSTRUCTOR QUALIFICATIONS \\
\hline Froperties of Ideal Instructor: \\
High degree of technical knowledge, \\
skills, and work experience \\
Necessary skills to train and evaluate \\
assigned trainees \\
Effective communicator \\
\end{tabular}

\section{COMMON ERRORS}

Trying to teach too much

Attempting to teach too fast

Lack of communication of training plans

Failure to recognize individual differences

Failure to provide practice time

Failure to show "big" picture

Failure to give reinforcement

Intimidation of trainee

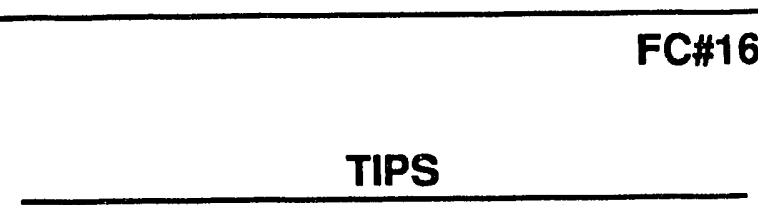

Prepare to train

Put trainee at ease

Avoid teaching in reverse

How to do on-the-job training 


\section{ON-THE-JOB TRAINING SKILLS FOR SUPERVISORS AND MANAGERS}


: the game ag paragraon fbllitil oi the Hern rute. CSFA consicers that those ovisions airegcy aopiy, jut they are c:ícsily cross reierenced because ey are pariculariy important since sigrincast excavalion activity oiten oczirs on hazarcious waste sites.

Paragrzonin (b)(3) would require emoioyers to notify contractors and subcontrac:ors of the hazarcis identined by the emolover at hazarcous waste operations. The language of $(b)(3)$ is the same as paragraon (b)(25) of the interim rise. Secions 1as(b)(2) and 12s/e) of SARA indicate Congress's soecintc interest in protecting empioyess of contrac:ors. and in invoiving contracion in ine saie operation of hazarcous ivaste sttes. This provision wouid assist the contractor in becoming aware of the operationai risks so that the contrac:or's empioyees may be better protec:ed.

Paragraon lot Sile Characierizotion onc inaysis

The emroiover needs to know the hazarcs faced by emoloyees in orcier to deveioo anc inolement er̃ecsive controi measures. Site crarac:er:zanon orovies the inionation reeded to identivy site hazaris and to seiec: empioyee protec:ion methocis. The more accurate. detailed. anc corroresenstve the iniomation avaiiabie goout as ste. the more the protective measures can be

iores to the acsual hazards that the oiovees ray ercounter. Cuszzess eariy intencied that sucis. a reouirement be inciucied Section 12Sib)(z/ of SriRA provicies that the proposal inciucie "recuirements for a jomal bazard anaiysis of the site .... Thereiore. CSirit is proposing to use the lanquage from the interm rule as the language for the proposed paragrapin (c).

It is imporzane to recognize that site ciaractertzation is a conumuous process. At caci phase of site ciarac:er:=3tuon iniormation is obtalned and evaiuated to derine tre potentral hazaris of the site. This assessment is to be used to devriop a saiery and beaith pian for the next praye ni worix. in acidition to. the iomal iniormintion gathersg that takes piace durgg the pisases oi site ciarac:erization descibed above: ad site personnet siouid be constantly alert ior new.iniormation about site conditions.

\section{Parogmpis (d)-Site Control}

This paragrapin wouvi require the empiover to deveiod a site control program as part of the employers' site saiety and heaith plan. to minimize potential contamsnation of employees. This program would be a part of the saiery and heaith progrem required by raprapin (b). Several itema. sucin as estabilishing work zanes. need :o Je consicered go inat emplovees krow ise hazarcs in cï̈ierent areas, snd :s:s wiil kees out of hazzrcious areas where thets presence is not requred.

Sile control is esci emerzency struatuo would cesc-ioe thi components of a = ac:ivities and mo and equipment at site.

The text propc has been aciapie The need for sit item $S$ or the $E$ acditior Suoo: rovides ior te? sites so hazari controilec.

bscrspacis le

The srodo provisions it

oi empioyee

jermitted :I

overations

saiesy and

:asibila; c

routise :-

proposad.

tainisg;

ezroioye

sxilis ne

waste $c$

Tsx :0 :

The :

tominas

al Ce:

and $s$.

state

in

misis

inst

of :

unc of recuirements uncer secsion iss/d) of S.ARA ior the proposed Inai stanciarcThe proposed requirersent is a one-tiese extor by the emoioyer ior each. enpioyee covered by this:stanciard. Employees do not need to be rernined for 40 hours at eacis site at whici they wori E-opoyess who have receivec the required Eatrung at one site can use that traiaing to meet this requirement at other sttes even if it tovoives a cifferent emoloyer.

Toere are oitta many husaris at a waste site: The empioyee wouid be trained to recogaize the hazaris and approprate work practices to minimize those hazaric. The employee wouid aiso be well trained in the use of resctrators and other iorms of personal proiecnve

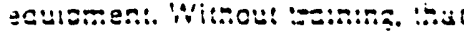

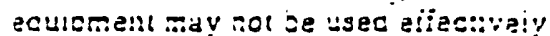
dra nay not srovice acecuate protec:on. Al ex:ensive :315:no zecerar: is necessary io assure :sas minimum of 40 hours of initial instruction off the site, and a minimum of three days of actual field experience under the direct supervision of a trained and experienced supervisor, at the time of job assignment. Congress has specifically imposed these hour and day requirements under section 128 (d) of SARA for the proposed final standard. The proposed requirement is a onetime effort by the employer for each employee covered by this standard. Employees do not need to be retrained for 40 hours at each site at which they work. Employees who have received the required training at one site can use that training to meet this requirement at other sites even if it involves a different employer. 


\section{INTRODUCTION TO ON-THE-JOB \\ TRAINING (OJT)}

Terminal Objective:

The OJT instructor will describe the basic OJT process, list several advantages and disadvantages of OJT, and explain why the first-line supervisor is usually the best qualified person to conduct OJT and evaluate employee learning.

Enabling Objectives:

1. Define performance-based training

2. Define on-the-job training

3. Explain how OJT differs from job experience

4. Describe the steps in a very basic OJT process

5. Describe the roles of the instructor and trainee in OJT

6. List two advantages and disadvantages of OJT 7. Describe why it is desirable to use the first-line supervisor as the OJT instructor and evaluator

8. Describe the eight common training errors committed by first-line supervisors 
The Learning Objectives

The Standards

Trainers and Evaluators

Documentation 


\section{BASIC OJT PROCESS}

Notes

Introduction

Explanation

Demonstration

Practice Under Supervision

Conclusion

Documentation

Evaluation 


\section{ROLE OF TRAINEE AND INSTRUCTOR}

Notes

\section{Trainee}

- Listen/Take Interest

- Observe

- Ask Questions/Discuss

- Perform Enabling Objectives

- Exercise/Repetition

- Perform Terminal Objective

Instructor

- Motivate/Orient

- Explain

- Demonstrate

- Monitor/Assist

- Question/Discuss

- Evaluate/Repeat 


\section{ADVANTAGES OF OJT}




\section{DISADVANTAGES OF OJT}

Notes

VII -17

TRADE SARA/OSHA Training: March 1989 


\section{INSTRUCTOR QUALIFICATIONS}

\section{Properties of Ideal Instructor}

- High degree of technical knowledge, skills, and work experience in subject areas.

- Possesses necessary skills to train and evaluate assigned trainees.

- Must be an effective communicator. 


\section{COMMON TRAINING ERRORS COMMITTED BY SUPERVISORS}

Trying to teach too much

Attempting to teach the individual too last

Notes

Lack of communication of training plans

Failure to recognize individual differences in trainees

Failure to provide practice time

Failure to show trainee the big picture

Failure to give reinforcement

Intimidation of trainees 
Prepare to train

- Prepare training outline

- Prepare self

Put trainee at ease

- Establish rapport

- Build interest

Avoid teaching in reverse

How to do on-the-job training

- Do in small bits

- Follow four steps of modeling

1. Teach

"I'll do one"

2. Monitor and Adjust

"I'll do and you help"

3. Supervised Practice "You do and I'll help"

4. Independent Practice "You do one" 
Action to be checked:

Yes

No

1. Is the supervisor mentally prepared for the training?

2. Is the supervisor technically prepared for the training?

3. Does the supervisor have a recent and accurate job analysis of this particular job?

4. Has the supervisor provided for an area for the training to take place?

5. Does the supervisor have specific performance objectives available? 


\section{TRAINING LOCATION CHECKLIST}

Action to be checked:

Yes

No

1. Has the training place been checked for availability?

2. Is the training location free of debris and raw materials?

3. Are the acoustics satisfactory in the training location?

4. Has the equipment itself been checked?

5. Do the people associated with the training location know that training is going to be taking place?

6. Is the training location enough like the real environment to give a feel for reality?

7. Is there an alternate location in case of a problem? 


\section{EMPLOYEE PREPARATION CHECKLIST}

Action to be checked:

Yes

No

1. Is the employee mentally prepared for the training?

2. Is the employee aware of personal deficiencies?

3. Is the employee able to understand and apply this training?

4. Does the employee know when the training will take place and about how long it will last?

5. Does the employee know and understand what is expected after the training is over?

6. Does the employee see the training as an opportunity? 
Insert site-specific examples of OJT checklists, etc. 


\section{POTENTIAL PROBLEM ANALYSIS AND CONTINGENCY PLANNING}

SCOPE

This module describes potential problem analysis (PPA) and contingency planning techniques. Its purpose is to enable the manager or supervisor to (1) systematically anticipate problems or conditions that may threaten the health and safety of workers and the integrity of the environment, and (2) prevent or minimize the impact of these problems.

(Suggested time - 2 hours)

\section{PARTICIPANT GOALS}

1) State the purpose of potential problem analysis.

2) State the two basic questions asked by PPA.

3) Review the use of the Kepner-Tregoe model for potential problem analysis.

4) Review the preventative and emergency elements of contingency planning.

5) Recognize the importance of developing a contingency plan to contain, control, and minimize the impact of all possible emergencies at a hazardous waste site.

6) Identify specific emergency conditions at a hazardous waste site and the best ways to handle each one.

7) In a group exercise, apply potential problem analysis and contingency planning to a hazardous waste remediation project scenario. 


\section{INSTRUCTOR PREPARATION}

1. Assemble viewgraphs.

2. Prepare a hazardous waste remediation project scenario. Develop a scenario based on chemicals, substances, and conditions, specific to your site, or use ORNL's scenario, "HAZWADIP \#4 Cleanup," and the accompanying handout on the toxic hazards mentioned in the scenario (pages VIII-12 through VIII-23).

3. Prepare worksheets for identifying and assessing major threats and possible emergencies. (Note: ORNL made copies of the worksheets into viewgraphs and enlarged the worksheets to poster size in addition to providing them as handouts. Each group was given poster-size worksheets to fill out so that they could present their findings and compare them with other groups (page VIII-10 through VIII-11).

4. Prepare handouts:

"Potential Problem Analysis" (page VIII-5);

Table I-III and Figure I (pages VIII-6 through VIII-9);

Handouts related to the group exercise, e.g., worksheets, scenario, and background information on toxic hazards.

5. Determine appropriate time allotment for group activity and presentations.

(Suggested time - 30 minutes for group activity and 10 minutes for each presentation)

6. Prepare lecture notes. 


\section{INSTRUCTIONAL ACTIVITIES}

1. Introduce the subject and explain that the theory of potential problem analysis and contingency planning will be covered, followed by an in-class group exercise.

(mgrprblm)

A. POTENTIAL PROBLEM ANALYSis

1. Introduce the concept of potential problem analysis and discuss its purpose of enabling supervisors to anticipate future threats and to prevent or minimize them. Stress that anticipating problems and their effects can increase managerial effectiveness and level of comfort.

(PPA1-D1 and PPA2-D1)

2. Describe PPA as a dynamic process with no unique starting point and no definite end. The actions taken, whether preventive, contingent, or both, will depend upon the problem, economics, feasibility of implementation, and common sense.

3. Discuss the two basic questions asked by PPA.

4. Explain the four activities that provide the framework for PPA. Ask participants to identify recent job situations in which this type of applied thinking would have prevented problems and to suggest specific ideas that would have been helpful in the situations.

(PPA4-D1 and the "Potential Problem Analysis" handout)

5. Briefly review the Kepner-Tregoe model for potential problem analysis.

6. Summarize PPA by presenting six questions that can be used in preparing or reviewing an action plan.

(PPA5-D1)

B. CONTINGENCY PLANNING

1. Introduce contingency planning and the importance of detailed planning in successful control of the broad range of environmental, safety, and health problems that hazardous waste sites can present. 
2. Review the elements of site health and safety planning that act as preventive measures against potential problems, incidents, or emergencies. Draw upon past SARA/OSHA topics (see Vol. 1) for discussion.

(mgrtrn01 and 02, handouts; Tables I-III, Figure 1)

C. GROUP EXERCISE

1. Introduce the group exercise as an application of potential problem analysis and contingency planning.

2. Refer participants to the scenario handout (your own or ORNL's "HAZWADIP \#4 Cleanup") and to the two worksheets entitled "Identifying and Assessing Major Threats and Possible Emergencies."

(MTEX7 and MTEX8)

3. Refer participants to the part of the scenario handout that provides toxic hazard ratings for the specific substances mentioned.

4. Divide the participants into groups of four or five. Using the scenario, ask them to list several possible events and emergencies that may threaten worker health and safety or may have a negative impact on the environment. For each event, instruct the participants to indicate the probability and seriousness of the occurrence. Instruct them to identify preventive measures or contingent actions that could lessen the impact of such an event. [Facilitate the exercise by visiting each group to offer suggestions and answer questions. Allow appropriate time for this group activity (about 30 minutes).]

5. Request that a representative from each group present the group's listing of events and actions to the class.

6. Review the importance of PPA and contingency planning to hazardous waste site activities. Discuss any questions raised by the exercise. 
Purpose: Thorough Consideration of the Future for Improved Assurance of Success

\section{ACTION PLAN STATEMENT}

-What overall action or responsibility has to be completed successfully?

\section{OUTLINE STEPS OR ELEMENTS}

- What are the major steps involved in completing this activity? When are they to be completed?

- What are the elements or necessary results to be achieved to complete this overall responsibility successfully?

- Which are most critical?

\section{ANTICIPATE SPECIFIC POTENTIAL PROBLEMS}

-What are the specific potential problems in each step or element? What could go wrong?

- How likely is it that this problem could happen? Probability: $10-1$ or $H, M, L$ scales

- How seriously will it affect the success of this effort if it happens? Seriousness: $10-1$ or H,M,L scales

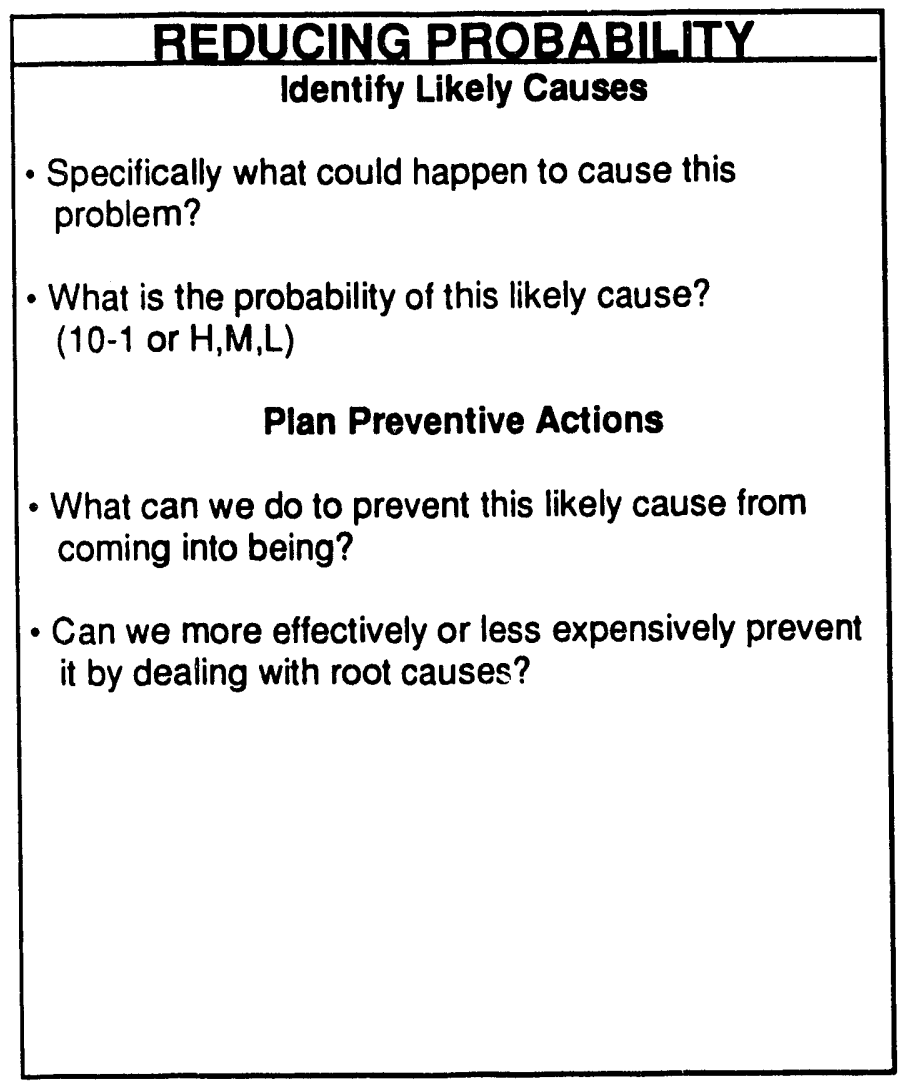

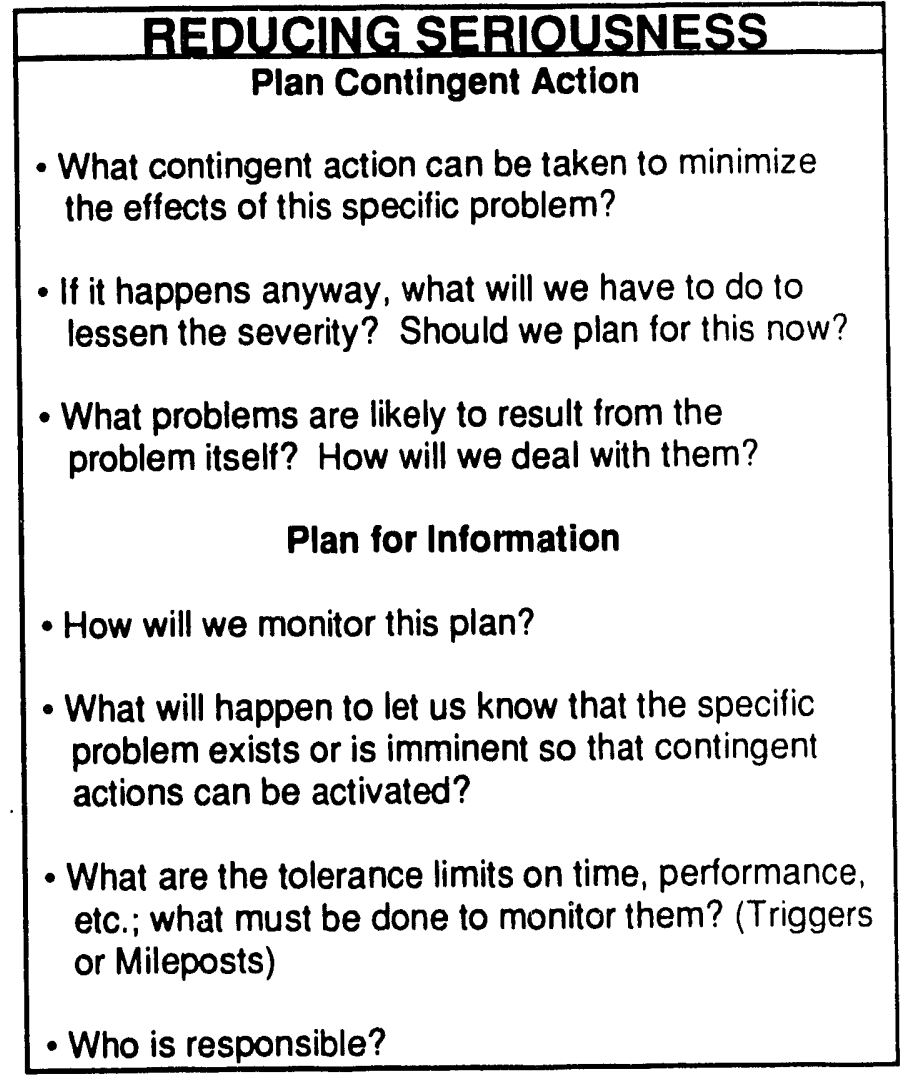

\section{MODIFY ORIGINAL PLAN}

Incorporate into the original list of steps or elements your:

- Preventive actions

- Contingent actions

- Information monitors

SOURCE: C. H. Kepner and B. B. Tregoe. 1981. The New Rational Manager. Princeton, NJ: Kepner-Tregoe, Inc.

TRADE SARA/OSHA Training: March 1989 
Table I.

Site Characteristics of Uncontrolled

Hazardous Waste Sites

Site Characteristics

Related Considerations

Topography

Geology

Hydrology

Climatology

Wildlife

Ground cover

History of sampling/ exploration

Accessibility

Security
Adjacent tenants

Nearby population centers

Hospital facilities

Ambulance service

Utilities available/ proximity

Industrial equipment rental

Law enforcement

Fire district 
Table II.

Assessment of Key Waste Characteristics

at the Waste Site

1. Sources/volume/form

2. History of waste deposits
a. Dates
b. Sources of waste
c. Type and quantity of wastes

3. Sources of additional information

4. Containment/confinement of waste

5. Waste conteiners (Types, age, condition)

6. Designed confinements (Pits, lagoons, cells, trenches, cover)

7. Uncontrolled practices at the site
a. Open dumping
b. Open burning
c. Flooding/evaporation/percolation

8. Hazardous properties of waste site chemicals

a. Physical and chemical properties (Flammability, corrosivity, reactivity)

b. Potential toxicity (Acute, chronic)

9. On-site waste compatibility considerations 


\section{Table III.}

Uncontrolled Hazardous Waste Site Incident Cases

1. Fire and/or explosion of flammable or combustible solvents or pesticide mixtures.

2. Explosion of waste containers containing shock, pressure or heat sensitive materials.

3. Penetration or rupture of compressed gas cylinders (buried or at the surface) containing toxic materials.

4. Penetration of protective gear by toxic liquids, gases or vapors.

5. Penetration of protective gear by equipment movement, flying debris, or contact with sharp cbjects.

6. Interruption or contamination of supplied breathing air.

7. Excavation and surface cave-ins.

8. Equipment rollovers.

9. In transit leaking or rupture of sample containers.

10. Rupture or leakage of sample containers while in storage.

11. Violent reaction of waste samples with analytical reagents.

12. Medical emergency in hazardous area (e.g., heart attack). 


\section{Figure 1}

Three frequently used zones in hazardous waste site control.

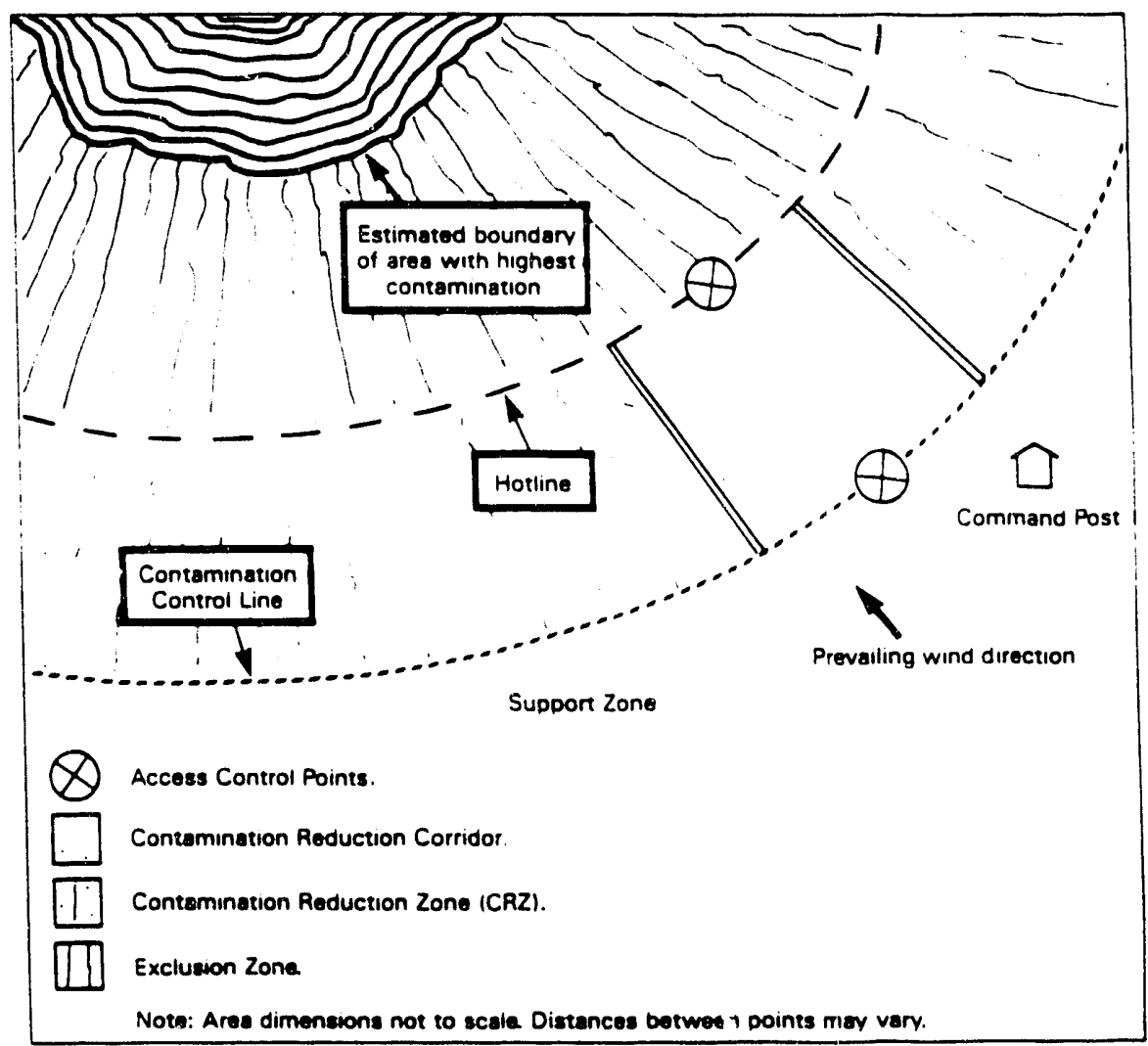

Exclusion Zone - The contaminated area typically requiring the most stringent levels of personal protective equipment. This zone can be subdivided into different areas of contamination based on the known or expected type and degree of hazard. Different levels of protection may be requilred for each of these subareas.

Contamination Reduction Zone - An intermediate buffer zone between contaminated and uncontaminated work areas. All decontamination activities occur in this area.

Support Zone or Clean Zone - The outermost areas of the site where workers should not be exposed to hazardous conditions. Typically this area contains the bulk of the administrative and support services, and serves as the focal point for controlled access of authorized support personnel and equipment. 

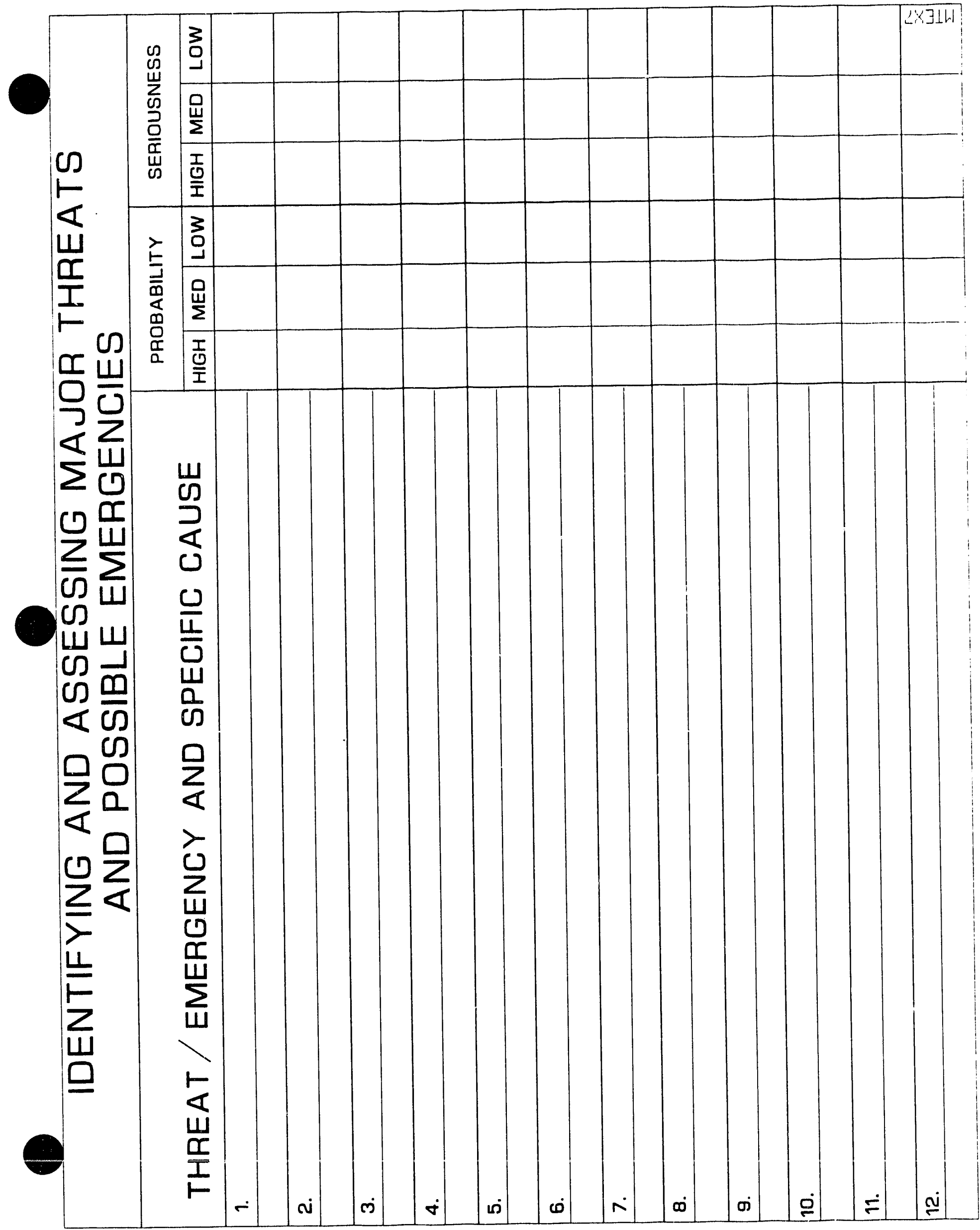


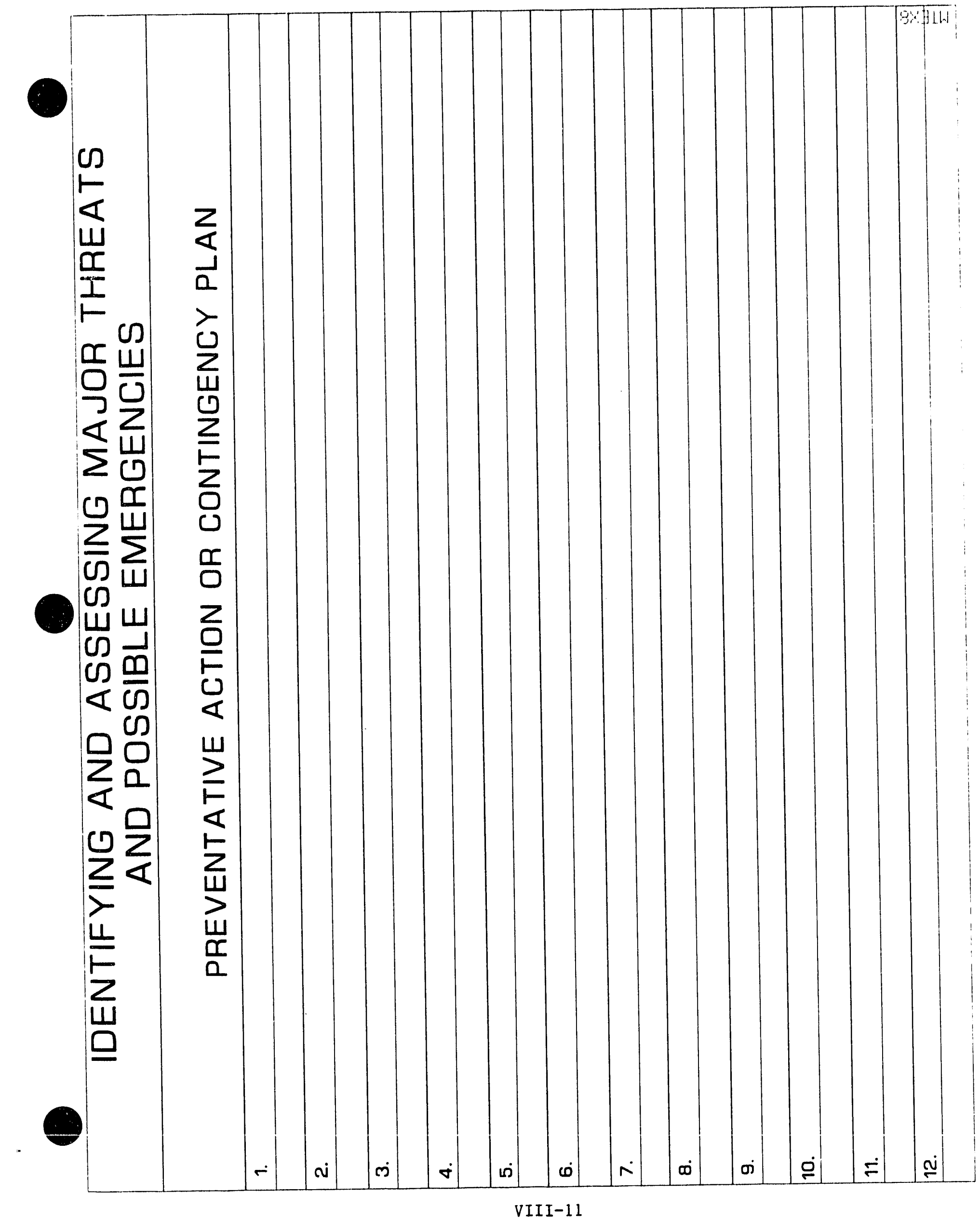




\section{HAZWADIP \#4 CLEAN UP \\ PINE RIDGE NATIONAL LABORATORY}

As a part of the federal Megafund program to clean up inactive hazardous waste sites, Pine Ridge National Laboratory (PRNL) has received funds to clean up 12 Hazardous Waste Disposal Pits (HAZWADIPs).

You are responsible for cleanup activities at HAZWADIP \#4, scheduled to begin on August 1. The site has not been used since early 1960, and a fire in 1957 destroyed all records of substances buried in the pit prior to that time. Furthermore, it is known that only about 508 of the buried waste was. generated at PRNL, with the remainder contributed by off-site generators. Consequently, little information is available as to the types, concentrations, and quantities of wastes disposed of at HAZWADIP \#4.

Significant quantities of heavy metals, primarily lead, are known to have been placed in HAZWADIP \#4. In addition, cadmium, copper, nickel, and zinc have been detected. The inclusion of building and construction rubble make the presence of asbestos likely. PCB-contaminated oils are known to have leaked from transformers at some locations, and it is possible that PCB - contaminated materials may have been placed in burial areas. Organics, including aromatic hydrocarbons such as benzene and halogenated

hydrocarbons, have been detected. (Only minimal efforts have been made to characterize organic contaminates, however.) Based on operations conducted during the 1950's a variety of acids and caustic substances are expected to be encountered during cleaup, including chromic acid, nitric acid, and perchloric acid.

Sampling of wells and streams in and near HAZWADIP \#4 has shown radioactive contamination of both groundwater and surface water. Although the principal radionuclides present in the groundwater are tritium and strontium-90, occasional water samples are found to contain small amounts of cobalt-60 and cesium-137.

The land-filled pit itself attains a maximum depth of approximately 20 feet. It is expected that the condition of the drums and other containers (plastic bags, covered buckets, etc.) that were buried has deteriorated over the years. Although some of the containers will be undamaged, some will have rusted or corroded and others will be bulging or leaking. Few labels will provide identification of the contents. 
Due to the recently enacted Megafund Amendments and Reauthorization Act, all workers involved in cleanup activities must be thoroughly trained in hazard recognition and health protection.

There have been frequent tornado and thunderstorm warnings.

HAZWADIP \#4 is located low in the valley of a tributary creek of the Trench River.

A frequently traveled roadway accessing the laboratory runs alongside one boundary of the pit area.

The area surrounding PRNL is generally rural to urban. Sizable residential communities and one large population center are within a ten-mile radius of HAZWADIP \#4. 
TOXIC HAZARD RATING CODE

0 None No harm under any condition or harmful only under unusual conditions or overwhelming dosage.

1 slight causes readily reversible changes which disappear after end of exposure.

2 Moderate May involve both irreversible and reversible changes not severe enough to cause death or permanent injury.

3 High May cause death or permanent injury after very short exposure to small quantities.

$\mathrm{U}$ Unknown No information on humans considered valid by authors. 


\section{ASBESTOS}

Synonyms: Asbestos dust, amosite, amphibole

Hazard Analysis:

Toxic Hazard Rating: Acute Local:

Acute Systemic:

Chronic Local:

Irritant 1; Inhalation 2

Chronic systemic:

0

Inhalation 3

Inhalation 3

Toxicology: The essential lesion produced by asbestos dust is a diffuse fibrosis which probably begins as a "collar" about the terminal bronchioles. Usually, at least 4 to 7 years of exposure are required before a serious degree of fibrosis results. Prolonged inhalation can cause cancer of the lung, pleura and peritoneum, and has experimentally produced cancers of the peritoneum and intestine. 


\section{BENZENE}

Clear colorless liquid

Synonyms: Benzol, Phenyl hydride, coal naphtha

\section{Hazard Analysis:}

Toxic Hazard Rating

Acute Local:

Irritant 2; Ingestion 1, Inhalation 1

Acute Systemic:

Chronic Local:

Ingestion 2; Inhalation 2 ; $\operatorname{skin} 2$

Chronic systemic:

0

Ingestion 3; Inhalation 3 ; Skin 2

Toxicology: Poisoning occurs most commonly through inhalation of the vapor, though benzene can penetrate the skin, and thus contribute to poisoning.

Locally, benzene has a comparatively strong irritating effect producing erythema and burning, and in more severe cases, edema and even blistering (Section 9). Exposure to high concentrations of the vapor results from accidents such as failure of equipment or spillage. Such exposure, while rare in industry, may result in acute poisoning, characterized by the narcotic action of benzene on the central nervous system. The anesthetic action of benzene is similar to that of other anesthetic gases, consisting of a preliminary state of excitation followed by depression and, if exposure is continued, death through respiratory failure. The chronic, rather than the acute form of benzene poisoning is important in industry. It is a recognized carcinogen of the blood-forming tissues. There is no specific blood picture occurring in cases of chronic benzol poisoning.

In acute poisoning, the worker becomes confused and dizzy, complains of tightening of the leg muscles and of pressure over the forehead, then passes into a stage of excitement. If allowed to remain in exposure, he quickly becomes stupefied and lapses into coma. In nonfatal cases, recovery is usually complete and no permanent disability occurs. In chronic poisoning the onset is slow, with the symptoms vague; fatigue, headache, dizziness, nausea and loss of appetite, loss of weight, and weakness are common complaints in early cases. Later, pallor, nosebleeds, bleeding gums, menorrhagia, petechiae and purpura may develop. There is great individual variation in the signs and symptoms of chronic benzene poisoning. Note: Benzene is a common air contaminant.

Fire Hazard: Dangerous when exposed to heat or flame; can react vigorously with oxidizing materials.

Explosion Hazard: Moderate, when its vapors are exposed to

flame.

Disaster Hazard: Dangerous, highly flammable

$$
\text { VIII-16 }
$$

TRADE SARA/OSHA Training: March 1989 


\section{BERYLLIUM}

Grayish-white, hard light metal

Synonyms: Glucinum

Hazard Analysis:

Toxic Hazard Rating:

Acute Local:

Acute systemic:

Chronic Local:

Irritant 3; Inhalation 3

Inhalation 3

Chronic Systemic: Inhalation 3

Toxicology: Beryllium is a common air contaminant

Fire Hazard: Moderate, in form of dust or powder or when exposed to flame by spontaneous chemical reaction.

Explosion Hazard: slight, in the form of powder or dust 


\section{CHROMIC ACID}

Dark, purple-red crystals

Synonyms: Chromic anhydride, chromium trioxide

\section{Hazard Analysis:}

Toxic Hazard Rating

Acute Local:

Acute Systemic:

Chronic Local:

Irritant 3; Ingestion 3; Inhalation 3

Chronic Systemic:

Irritant 3; Ingestion 3; Inhalation 3

Ingestion 3; Inhalation 3

Toxicology: Chromic acid and its salts have a corrosive action on the skin and mucous membranes. The lesions are confined to the exposed parts, affecting chiefly the skin of the hands and forearms and the mucous membranes of the nasal septum. The characteristic lesion is a deep, penetrating ulcer, which, for the most part, does not tend to suppurate, and which is slow in healing.

Fire Hazard: Dangerous, a very powerful oxidizing agent. In contact with organic matter or reducing agents in general it causes violent reactions.

Explosion Hazard: Upon intimate contact with powerful reducing agents it can cause violent explosions. 
Bluish-gray, soft metal

Synenym: Plumbum

Hazard Analysis:

Toxic Hazard Bating

Acute Local: 0

Acute Systemic: Inhalation 3

Chronic Local: 0

Chronic Systemic: Ingestion 3; Inhalation 3

Toxicolzgy: Lead poisoning is one of the commonest of occupational diseases. The presence of lead-bearing materials or lead compounds in an industrial plant does not necessarily result in exposure on the part of the workman. The lead must be in such form, and so distributed, as to gain eritrance into the body or tissues of the workman in measurable quantity, otherwise no exposure can be said to exist. It is a suspected carcinogen of the lungs and kidneys.

Mode of entry into body:

1. By inhalation of the dusts, fumes, mists or vapors. (Common air contaminants).

2. By ingestion of lead compounds trapped in the upper respiratory tract or introduced into the mouth on food, tobacco, fingers or other objects.

3. Through the skin, this route is of special importance in the case of organic compounds of lead, as lead tetraethyl. In the case of the inorganic forms of lead, this route is of no practical importance.

Eire Hazard: Moderate, in the form of dust when exposed to heat or flame.

Explosion Hazard: Moderate, in the form of dust when exposed to heat or flame.

Disaster Hazard: Dangerous, when heated it emits highly toxic fumes, can react vigorously with oxidizing materials. 
NITRIC ACID

Transparent colorless or yellowish, fuming, suffocating, caustic and corrosive liquid.

Synonyms: Aqua fortis, hydrogen nitrate, azotic acid

\section{Hazard Analysis:}

Toxic Hazard Rating

Acute Local:

Acute Systemic:

Chronic Local:

Chronic systemic:

Irritant 3; Ingestion 3; Inhalation 3 Inhalation 3

Irritant 2

$\mathrm{U}$

Toxicology: The exact composition of the "fumes" or vapor produced by nitric acid depends upon such factors as temperature, humidity, and whether or not the acid comes in contact with other materials such as heavy metals or organic compounds. Depending upon these factors, the vapor will consist of a mixture of the various oxides of nitrogen and of nitric acid vapor. Nitric acid vapor is highly irritant to the mucous membranes of the eyes and respiratory tract and to the skin. It is corrosive to the teeth. Because of its irritant properties, chronic exposure. to dangerous concentrations of the acid vapor seldom occur.

Fire Hazard: Moderate, by chemical reaction with reducing agents. It is a powerful oxidizing agent.

Explosion Hazard: Slight, by chemical reaction to evolve $\mathrm{NO}_{\mathrm{X}}$; can explode on contact with powerful reducing agents. 
PERCHLORIC ACID

Colorless, fuming, unstable liquid

Hazard Analysis:

Toxic Hazard Rating Acute Local: Acute Systemic: Irritant 3; Ingestion 3; Inhalation 3 Chronic Local: Irritant 2; Inhalation 2 Chronic Systemic: $\mathrm{U}$

Toxicology: Perchlorates are unstable materials, and are irritating to the skin and mucous membranes of the body wherever they come in contact with it. Avoid skin contact with these materials.

Fire Hazard: Moderate, when shocked, exposed to heat or by chemical reaction. Perchlorates, when mixed with carbonaceous material, form explosive mixtures. They are considered a fire and explosive hazard when associated with carbonaceous materials or finely divided metals. This is also true of the presence of sulfur, powdered magnesium and aluminum.

Disaster Hazard: Dangerous, shock will explode them; when heated, they emit highly toxic fumes of chlorides; they can react with reducing materials. 
PICRIC ACID

Yellow crystals or yellow liquid. Very bitter.

Synonyms: Picronitric acid, trinitrophenol, carbazotic acid

\section{Hazard Analysis:}

Toxic Hazard Rating

Acute Local:

Acute systemic:

Chronic Local:

Chronic Systemic:

Irritant 2; Allergen 1

Ingestion 3; Inhalation 3 ; skin 2

Irritant 2; Allergen 2

Ingestion 2; Inhalation $2 ; \operatorname{skin} 2$

Toxicology: Can cause allergic as well as irritative dermatitis. Symptoms of systemic poisoning are nausea, vomiting, diarrhea, suppressed urine, yellow discoloration of skin and convulsions.

Explosion Hazard: Dangerous, when shocked or exposed to heat. Picric acid forms salts readily. Many of its salts, known as picrates, are more sensitive explosives than picric acid. This is particularly true of copper, lead and $z$ inc. metals. picric acid is a more powerful explosive than TNT. Its ability to form the sensitive picrates in contact with metal has somewhat limited its usefulness as an explosive.

Disaster Hazard: Highly dangerous; shock will explode it; on decomposition, it emits highly toxic fumes and explodes; can react vigorously with reducing materials. 
POLYCHLORINATED BIPHENYLS (PCBS)

\section{Hazard Analysis:}

Toxic Hazard Rating:

Acute Local: Irritant 2

Acute Systemic: Ingestion 3; Inhalation 3; Skin $\mathrm{Ab}-$ sorption 3

Chronic Local: Irritant 3

Chronic Systemic: Inhalation 3; Skin Absorption 2

Toxicology: Like the chlorinated naphthalenes, the chlorinated biphenyls have two distinct acticns on the body, namely, a skin effect and a toxic action on the liver. The lesion produced in the liver is an acute yellow atrophy. This hepatotoxic action of the chlorinated biphenyls appears to be increased if there is exposure to carbon tetrachloride at the same time. The higher the chlorine content of the biphenyl compound, the more toxic is it liable to be. oxides of chlorinated biphenyls are more toxic than the unoxidized materials.

The skin lesion is known as chloracne, and consists of small pimples and dark pigmentation of the exposed areas, initially, with development of pustules later. In persons who have sufferod systemic intoxication the usual signs and symptomi are nausea, vomiting, loss of weight, jaundice, edema, and abdominal pain. Where the liver damage has been severe the patient may pass into coma and die.

Fire Hazard: Slight, when exposed to heat or flame.

Disaster Hazard: Dangerous; when heated to decomposition, they emit highly toxic fumes. 


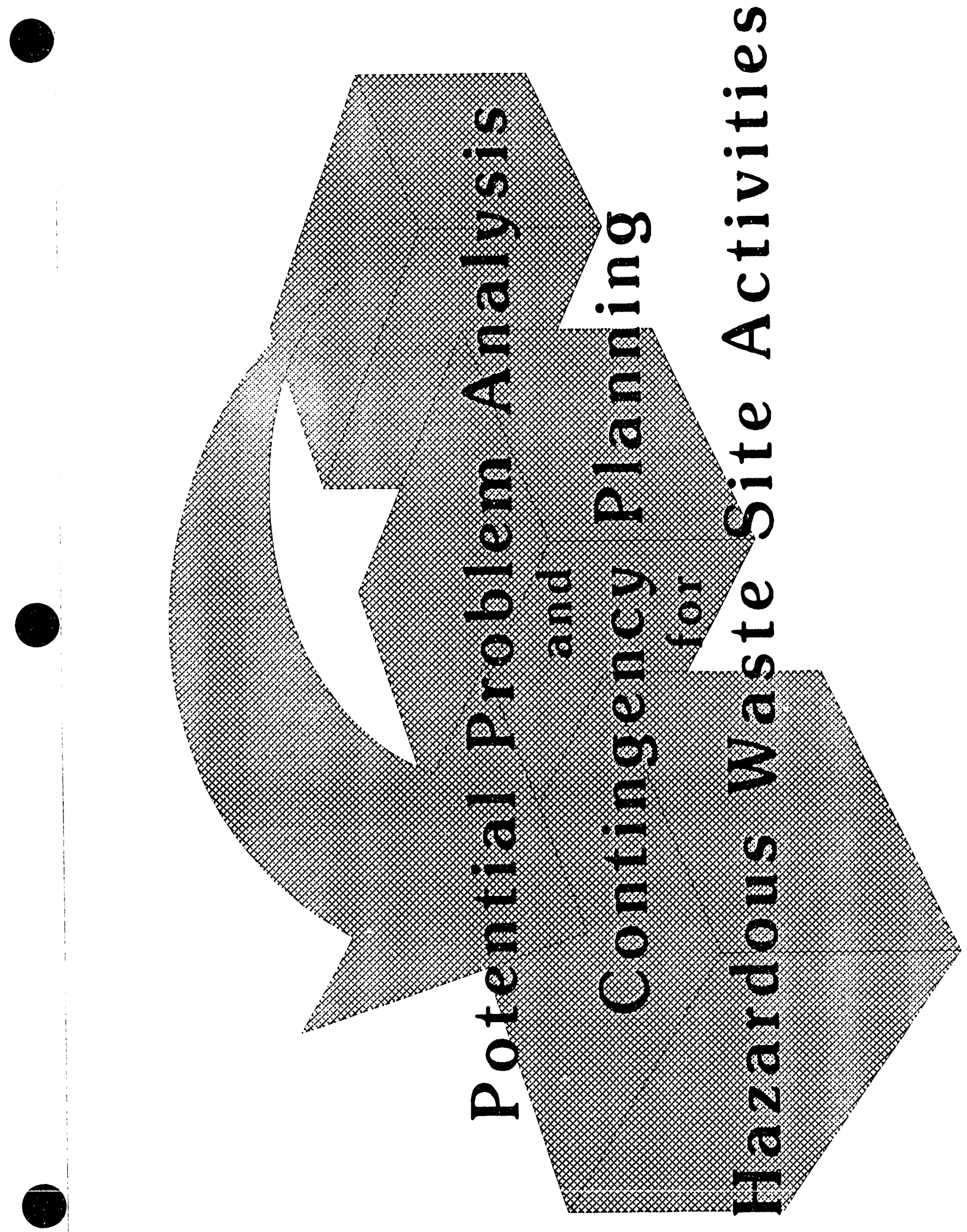

VIII -24

TRADE SARA/OSHA Training: March 1989 


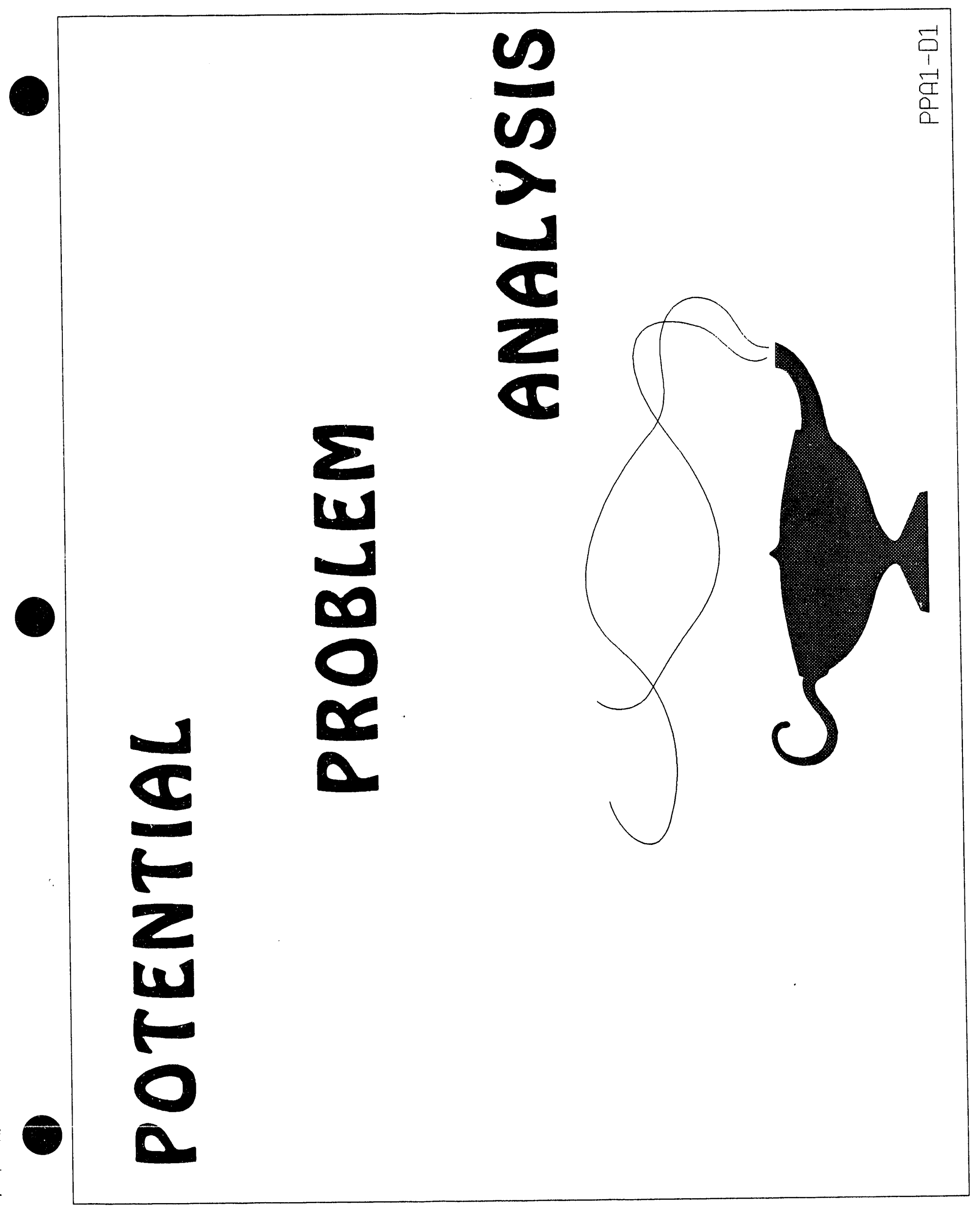

VIII-25

TRADE SARA/OSHA Training: March 1989 


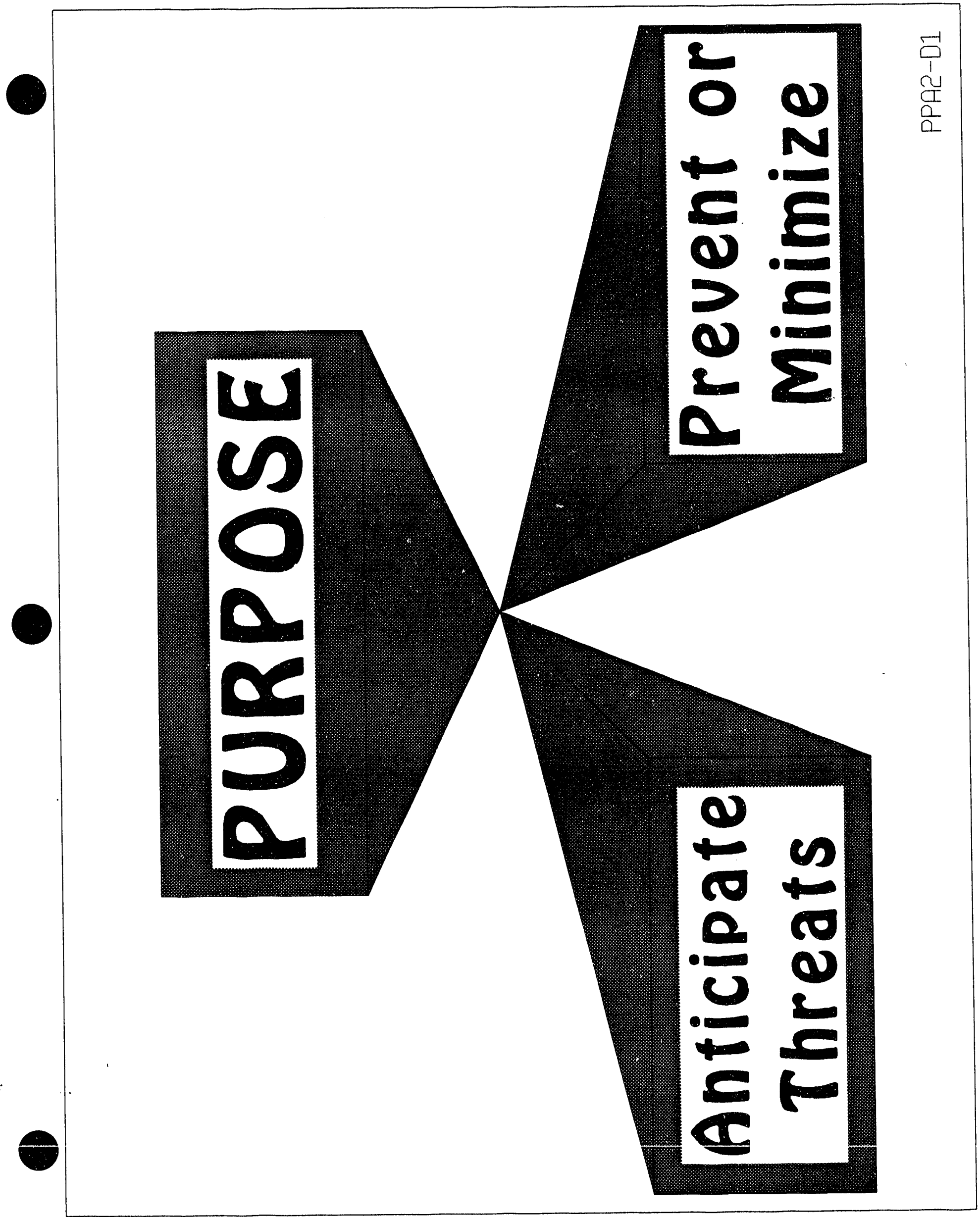

VIII-26

TRADE SARA/OSHA Training: March 1989 


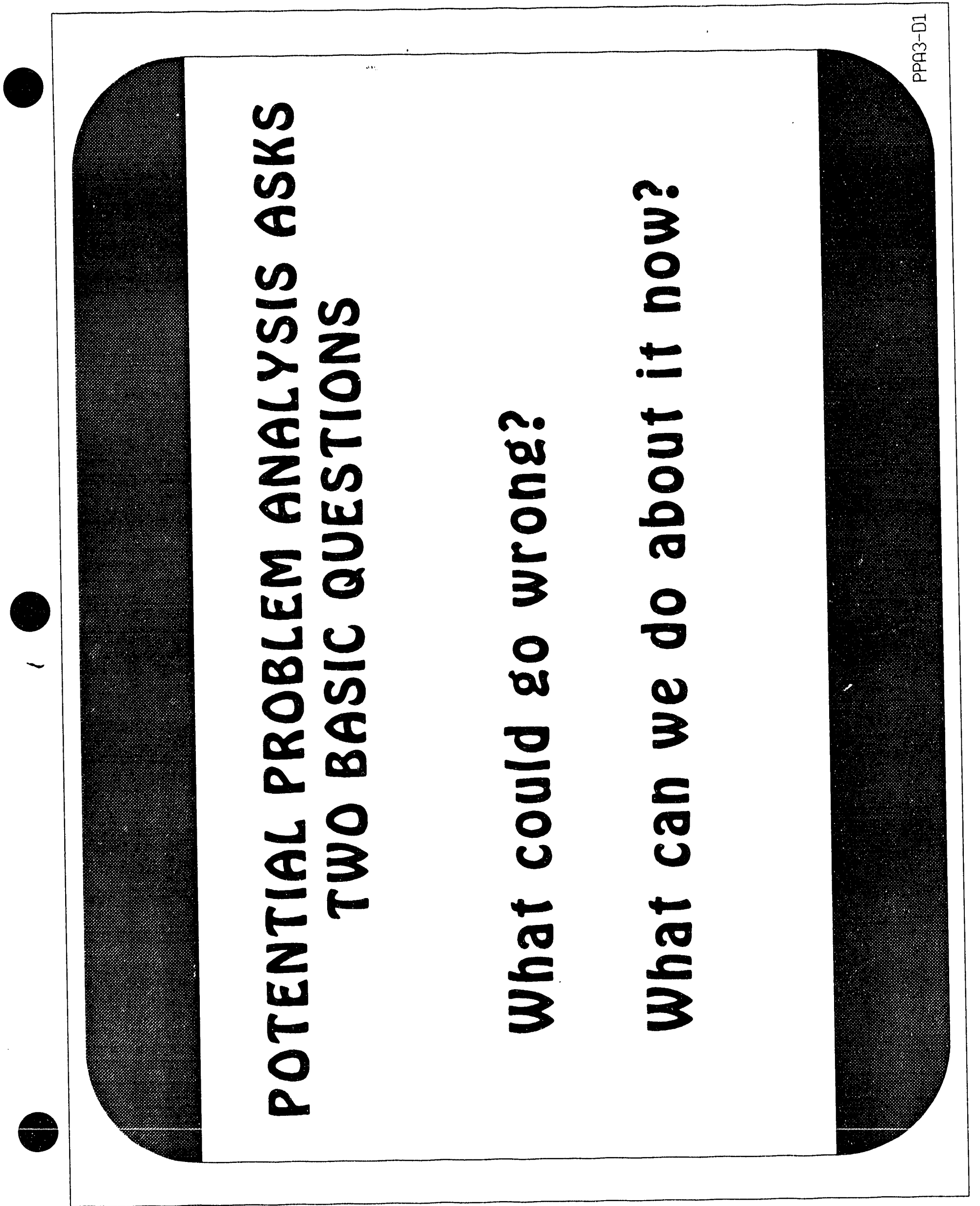




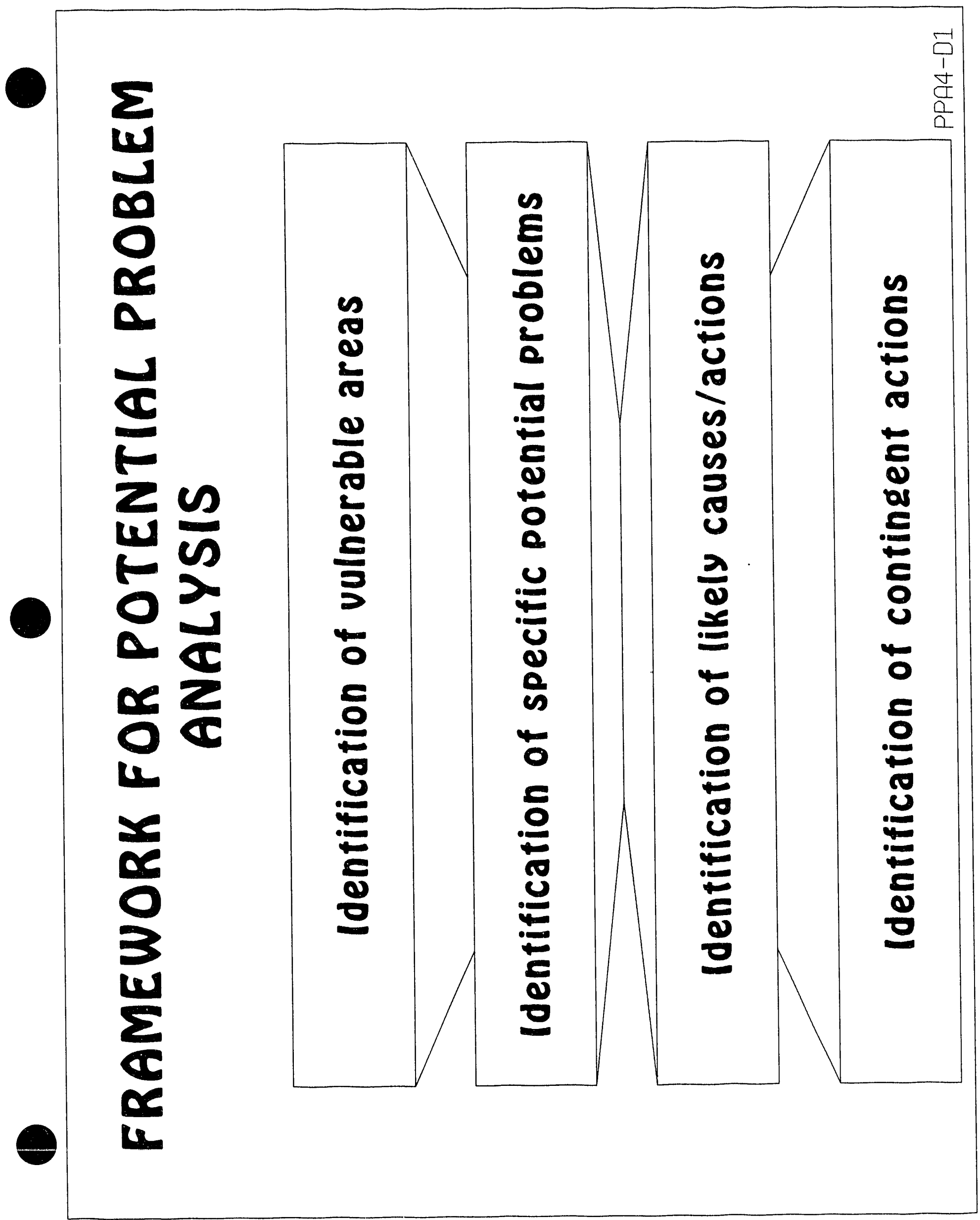




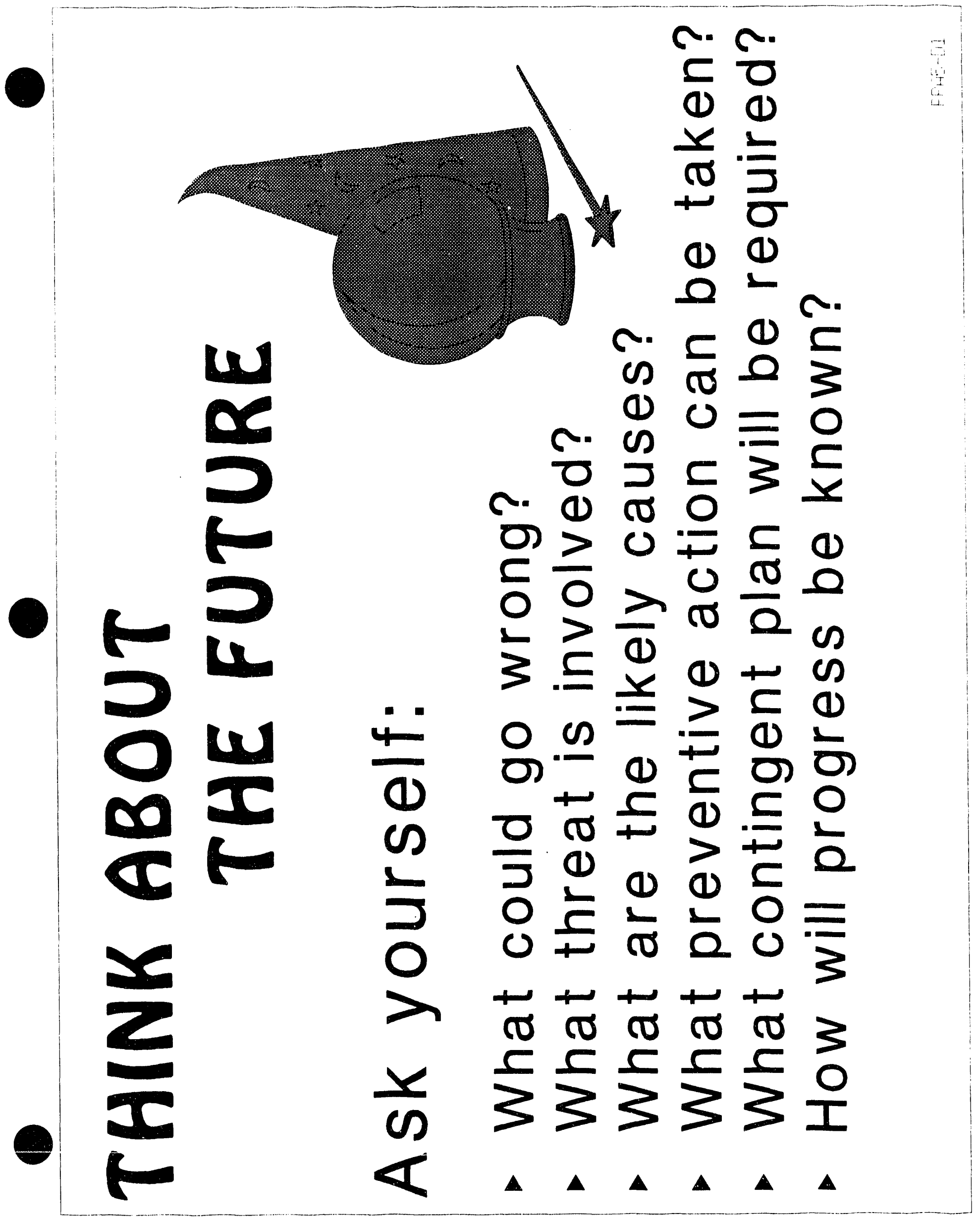




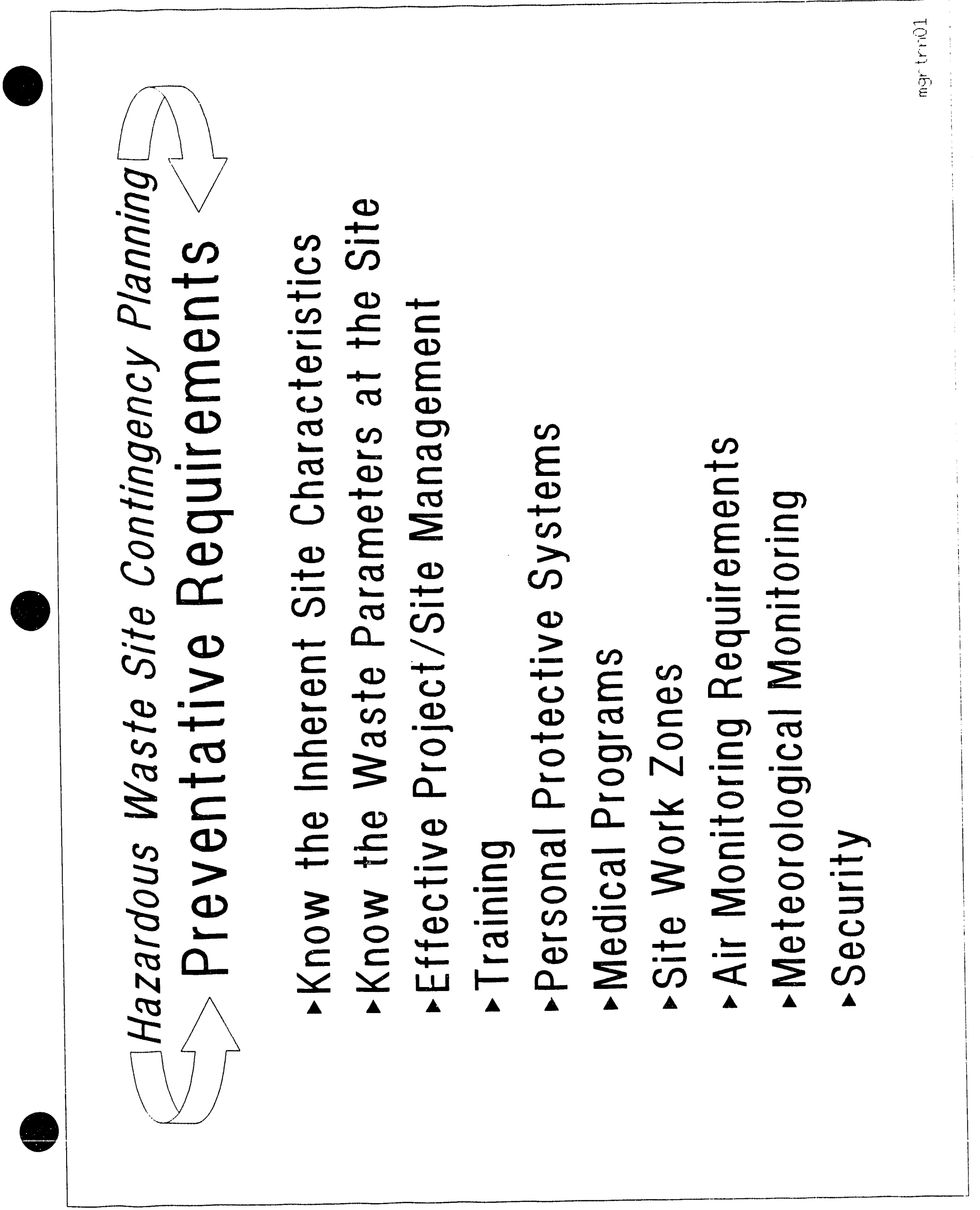




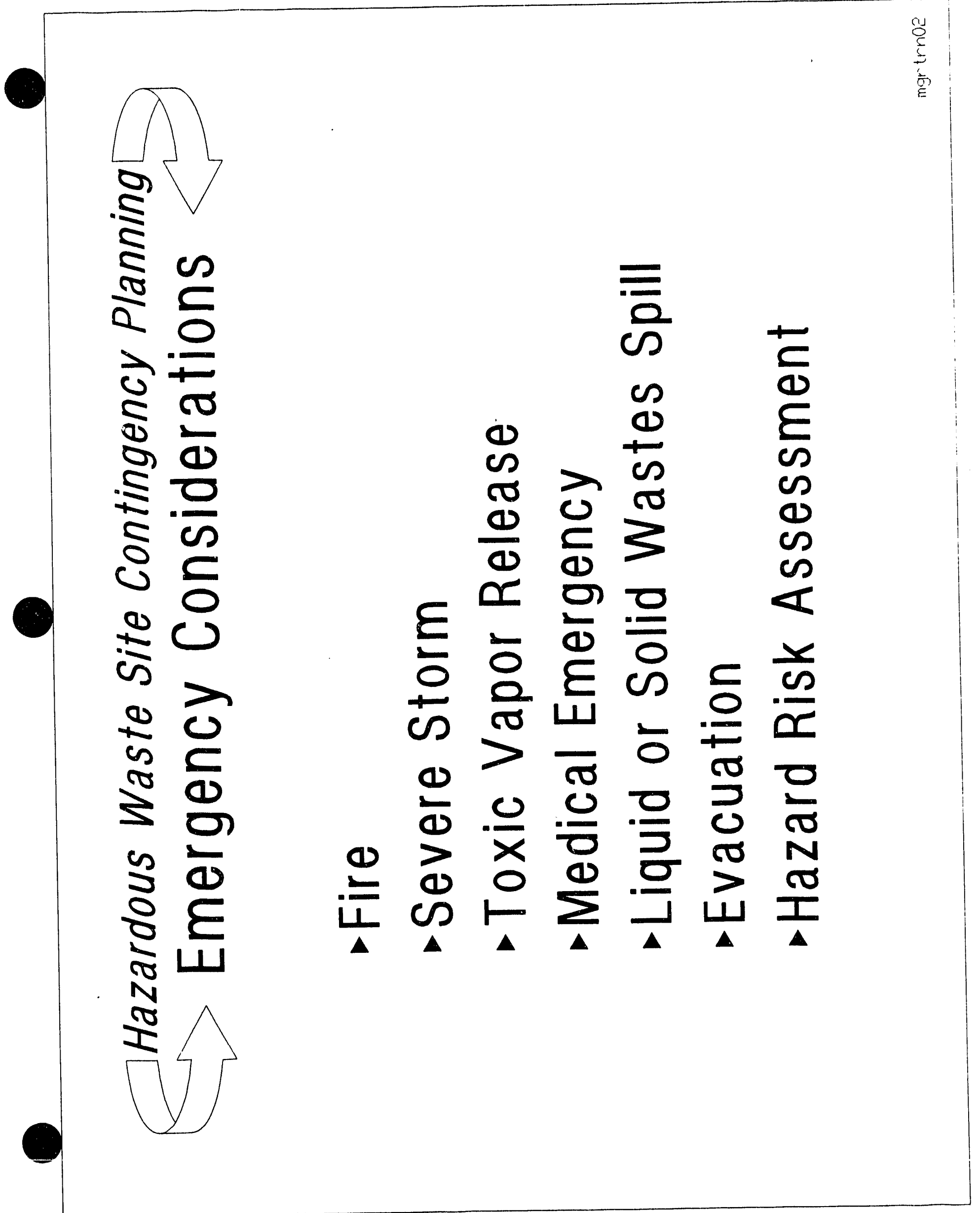




\section{REFERENCES \\ for \\ Selected Individual Modules}

MODULE I - Remedial Action Strategies

Rogoshewski, P. J. 1983. Remedial Action Technology for Waste Disposal Sites. Pollution Technology Review, No. 101. Park Ridge, NJ: Noyes Data Corporation.

Electric Power Research Institute and Edison Electric Institute. 1988. Remedial Technology for Leaking Underground Storage Tanks. Chelsea, MI: Lewis Publishers, Inc.

MODULE II - Handling the Press

Title III Community Awareness Workbook. 1988. Washington, DC: Chemical Manufacturers Association.

MOdULE III - Selection of Personal Protective Equipment (PPE)

National Institute for Occupational Safety and Health (NIOSH), Occupational Safety and Health Administration (OSHA), U. S. Coast Guard (USCG), U. S. Environmental Protection Agency (EPA). 1985. Occupational Safety and Health Guidance Manual for Hazardous Waste Site Activities. DHHS (NIOSH) Pubifation 85-115.

Perkins, J. L. 1987. "Chemical Protective Clothing: I. Selection and Use." Applied Industrial Hygiene 2:222-230.

Perkins, J. L. 1988. "Chemical Protective Clothing: II. Program Considerations." Applied Industrial Hygiene 3:1-4.

Ronk, R., M. K. White and H. Linn, 1985. Hazardous Waste Supplement to Personal Protective Equipment for Hazardous Materials Incidents: A Selection Guide, Springfield, VA: National Technical Information Service for National Institute for Occupational Safety and Health. 
Ronk, R., M. K. White, and H. Linn, 1984. Personal Protective Equipment for Hazardous Materials Incidents: A Selection Guide, Springfield, VA: National Technical Information Service for National Institute for Occupational Safety and Health.

Schwope, A. D., P. P. Costas, J. D. Jackson, D. J. Weitzman, 1987. Guidelines for the Selection of Chemical Protective Clothing, 3rd ed. Cincinnati, $\mathrm{OH}$ : American Conference of Governmental Industrial Hygienists.

MODULE V - SARA Title III: Emergency Planning and Community Right to Know

Industrial Training Systems Corporation. 1987. Leader's Guide to Title III: Emergency Planning and Community Right-to-Know. Marlton, NJ: ITS Corp.

MODULE VI - Legal Aspects of Supervision

Arbuckle, J. Gordon, Nancy S. Bryson, David R. Case, Colburn T. Cherney, Ridgeway M. Hall, Jr., John C. Martin, Jeffrey G. Miller, Marshall Lee Miller, William F. Pedersen Jr., Russel V. Randle, Richard G. Stoll, Thomas F. P. Sullivan, and Timothy A. Vanderver, Jr., 1987. Environmental Law Handbook, 9 th ed. Rockville, MD: Governmant Institutes, Inc.

"Comprehensive Environmental Response, Compensation, and Liability Act (CERCLA or Superfund)." Public Law 96-510, 11, Dec. 1980, 94 Stat. 2795 .

"Hazardous Waste Operations and Emergency Response." 29 CFR 1910.120. 52 Federal Register 29620, 10, Aug. 1987 (SARA).

National Institute for Occupational Safety and Health Administration (NIOSH), Occupational Safety and Health Adminstration (OSHA), United States Coast Guard (USCG), and Environmental Protection Agency (EPA). Occupational Safety and Health Guidance Manual for Hazardous Waste Activities. DHHS (NIOSH) Publication 85-115.

Novick, Sheldon M., Donald W. Stever, Margaret G. Mellon, and John P. C. Fogarty, 1988. Law of Environmental Protection, vol. 1. New York: Clark Boardman Company, Ltd., for the Environmental Law Institute. 
"Personnel Training." 40 CFR Part 265.16, 50 Federal Register 4514, 31, Jan. 1985.

"Resource Conservation and Recovery Act of 1976 (RCRA)." Public Law $94-580,21$, Oct. 1976, 90 Stat. 2795.

Rich, David A. 1986. "Personal Liability for Hazardous Waste Cleanup: An Examination of CERCLA Section 107," Boston College Environmental Affair Law Review 13(4): 643-671.

"Superfund Amendments and Reauthorization Act of 1986 (SARA)," Public Law $99-499,17$, Oct. 1986,100 Stat. 1613.

MODULE VII - On-the-Job Training Skills

Broadwe11, Martin M. 1986. The Supervisor and On-the-Job Training. Reading, PA: Addison-Wesley Publishing Company, Inc.

"Hazardous Waste Operations and Emergency Response." 29 CFR 1910.120. 52 Federal Register 2962, 10, Aug. 1987 (SARA).

Idaho National Engineering Laboratory 1987. Guide to Good Practices for On-the-Job Training, DOE/ID-10177.

MODULE VIII - Potential Problem Analysis and Contingency Planning

Levine, Steven P., and William F. Martin, eds. 1985. Protecting Personnel at Hazardous Waste Sites. Boston: Butterworth Publishers.

Kepner, Charles H., and Benjamin B. Tregoe, 1981. The New Rational

Manager. Princeton, NJ: Kepner-Tregoe, Inc.

National Institute for Occupational Safety and Health (NIOSH), Occupational Safety and Health Administration (OSHA), U.S. Coast Guard (USCG), U.S. Environmental Protection Agency (EPA). 1985. Occupational Safety and Health Guidance Manual for Hazardous Waste Site Activities, DHHS $\overline{(\mathrm{NIOSH})}$ Publication 85-115.

Sax, N. Irving. 1984. Dangerous Properties of Industrial Materials, 6th ed. New York: Van Nostrand Reinhold. 

